\title{
The Content of the 14 Metals in Cancellous and Cortical Bone of the Hip Joint Affected by Osteoarthritis
}

\author{
Anetta Zioła-Frankowska, ${ }^{1}$ Lukasz Kubaszewski, ${ }^{2}$ Mikołaj Dabrowski, ${ }^{2}$ \\ Artur Kowalski, ${ }^{3}$ Piotr Rogala, ${ }^{4}$ Wojciech Strzyżewski, ${ }^{2}$ Wojciech Labędź, ${ }^{2}$ \\ Ryszard Uklejewski, ${ }^{5,6}$ Karel Novotny, ${ }^{7}$ Viktor Kanicky, ${ }^{7}$ and Marcin Frankowski ${ }^{3}$ \\ ${ }^{1}$ Department of Analytical Chemistry, Faculty of Chemistry, Adam Mickiewicz University in Poznań, 61-614 Poznań, Poland \\ ${ }^{2}$ Department of Orthopedic and Traumatology, W. Dega University Hospital, Poznan University of Medical Sciences, \\ 61-545 Poznań, Poland \\ ${ }^{3}$ Department of Water and Soil Analysis, Faculty of Chemistry, Adam Mickiewicz University in Poznań, 61-614 Poznań, Poland \\ ${ }^{4}$ Department of Spondyloorthopaedics and Biomechanics of the Spine, W. Dega University Hospital, \\ Poznan University of Medical Sciences, 61-545 Poznań, Poland \\ ${ }^{5}$ Laboratory of Biomaterials and Peri-Implant Bioprocesses Engineering, Department of Process Engineering, \\ Institute of Technology and Chemical Engineering, Poznan University of Technology, 60-965 Poznań, Poland \\ ${ }^{6}$ Department of Medical Bioengineering Fundamentals, Institute of Technology, Casimir the Great University, \\ 85-064 Bydgoszcz, Poland \\ ${ }^{7}$ Department of Chemistry, Faculty of Science, Masaryk University, 61137 Brno, Czech Republic
}

Correspondence should be addressed to Anetta Zioła-Frankowska; anettazf@amu.edu.pl

Received 9 March 2015; Revised 24 June 2015; Accepted 25 June 2015

Academic Editor: Swaran J. S. Flora

Copyright (C) 2015 Anetta Zioła-Frankowska et al. This is an open access article distributed under the Creative Commons Attribution License, which permits unrestricted use, distribution, and reproduction in any medium, provided the original work is properly cited.

\begin{abstract}
The aim of the study was to determine the content of particular elements $\mathrm{Ca}, \mathrm{Mg}, \mathrm{P}, \mathrm{Na}, \mathrm{K}, \mathrm{Zn}, \mathrm{Cu}, \mathrm{Fe}, \mathrm{Mo}, \mathrm{Cr}, \mathrm{Ni}, \mathrm{Ba}, \mathrm{Sr}$, and $\mathrm{Pb}$ in the proximal femur bone tissue (cancellous and cortical bone) of 96 patients undergoing total hip replacement for osteoarthritis using ICP-AES and FAAS analytical techniques. The interdependencies among these elements and their correlations depended on factors including age, gender, place of residence, tobacco consumption, alcohol consumption, exposure to environmental pollution, physical activity, and type of degenerative change which were examined by statistical and chemometric methods. The factors that exerted the greatest influence on the elements in the femoral head and neck were tobacco smoking (higher $\mathrm{Cr}$ and $\mathrm{Ni}$ content in smokers), alcohol consumption (higher concentrations of $\mathrm{Ni}, \mathrm{Cu}$ in people who consume alcohol), and gender (higher $\mathrm{Cu}, \mathrm{Zn}$, and $\mathrm{Ni}$ concentrations in men). The factors influencing $\mathrm{Pb}$ accumulation in bone tissue were tobacco, alcohol, gender, and age. In primary and secondary osteoarthritis of the hip, the content and interactions of elements are different (mainly those of $\mathrm{Fe}$ and $\mathrm{Pb}$ ). There were no significant differences in the concentrations of elements in the femoral head and neck that could be attributed to residence or physical activity.
\end{abstract}

\section{Introduction}

Contaminated food, water, and air from industrial areas are the primary sources of metals in the human body [1]. Modern toxicology is dominated by issues related to exposure to chronic poisoning, which is associated with high levels of pollution [2]. Significant amounts of metals in the environment are the result of human activities; these metals participate in the metabolic processes of the body and pose serious threats to human and animal health. Interactions between elements may be either synergistic or antagonistic, causing deviations from their optimal range and resulting in secondary deficiency or toxicity $[3,4]$. Bone tissue that exhibits slow remodelling reflects long-term exposure to metals and this can be used to indirectly assess the exposure to metals from the environment $[5,6]$. Cancellous bone metabolism is more active than cortical bone and depends on many factors such as age, diet, and health status [7]. 
Many elements have a significant impact on bone metabolism [6]. The literature includes many reports on the content and relationships of elements in bone; however they mainly focus on other types of bone such as the tibia, patella, ribs, vertebrae, or the bones of the skull $[6,8]$.

The Role of Selected Metals in the Human Body. Zinc in cartilage and bone plays a role in growth and maturation and is involved in the hormonal regulation of intracellular signalling [9]. It has been proven that $\mathrm{Zn}$ deficiency leads to linear bone growth retardation, which is associated with dysfunction of growth hormone and insulin-like growth factor (IGF) dependent on the micronutrient [10]. Also, $\mathrm{Zn}$ has a powerful stimulating effect on osteoblasts, bone formation, and bone resorption by inhibiting the action of osteoclasts [11]. The expression of proteins that include $\mathrm{Zn}$ or play a role in its regulation, found in many cells of the connective tissue including osteoblast and osteocyte precursors, suggests an important role of the metal in the growth and maturation of bone [12]. Copper is a cofactor for lysyl oxidase, the enzyme responsible for the cross-linking of collagen fibres; disorders in the formation of crosslinks lead to a weakening of bone [13]. Copper deficiency leads to bone malformations during development, an increased risk of osteoporosis in the elderly. Some genetic diseases as Menkes syndrome and Wilson's disease are associated with severe $\mathrm{Cu}$ deficiency and severe $\mathrm{Cu}$ toxicity, respectively; they involve processes in the bone that involve $\mathrm{Cu}$ (osteomalacia, osteoporosis, and chondropathy) [14]. Copper also reduces the suppression of bone turnover by osteoblasts and osteoclasts [15]. An important role of $\mathrm{Fe}$ is its involvement in the formation of reactive oxygen species, which at low concentrations meets physiological demands, but, at higher concentrations, it is toxic to cells, causing their destruction $[4,16,17]$. The role of $\mathrm{Fe}$ in the bone tissue is not well understood. Iron is involved in the synthesis of collagen and the conversion of 25-hydroxy vitamin $\mathrm{D}$ to its active form. The Fe is necessary for the proper functioning of osteoblasts and excess Fe in osteoblasts may lead to metabolic bone disorders (osteoporosis, osteopenia, and osteomalacia) [13]. Strontium accumulates in bones and teeth (99\%), but its effect on these tissues is not completely understood [18]. It has been shown that the effect of $\mathrm{Sr}$ is dose dependent. Low doses can stimulate bone formation (by stimulating the differentiation of osteoblasts) and increase bone density (which increases the synthesis of collagen and non-collagenous proteins). It increases the rate of bone mineralization and strength (often replacing calcium in the structure), the extension of the crystal lattice, and the solubility of crystalline embryos and decreases the rate of resorption (inhibiting osteoclast differentiation) $[16,19]$. High doses of Sr may cause impaired mineralization and bone deformities due to abnormal calcium and phosphate metabolism [16]. Molybdenum in the human body accumulates in the liver, kidneys, bones, and teeth [20] An excess of Mo is toxic and causes bone deformities similar to the changes occurring in the rheumatoid arthritis, tooth decay, and disorders of lipid and protein [4]. Chromium builds stable complexes with proteins and has the ability to precipitate proteins, resulting in negative effects on the skin and mucous membranes. Allergy to chromium compounds is a common cause of eczema, characterized by oedema of the eyelids, blushing nettle, oedematous papules, and exudate on the face, neck, forearms, arms, hands, and fingers [4]. The role of nickel in the physiology of the human body is not well understood. In humans, $\mathrm{Ni}$ deficiency causes a decrease in oxygen consumption and an increase in the accumulation of liver fats. This occurs mainly in soft tissues, although its presence and influence in bone metabolism have also been confirmed [4, 16, 21, 22]. Barium is not metabolized by the body, but it can be transported or metabolically incorporated into tissue complexes. Toxic effects are associated with impaired digestive and respiratory systems, as well as the inhibition of bone mineralization [16]. Lead has the ability to accumulate in the body, mainly in the liver, brain, kidneys, muscles, and bones. Most (90-95\%) $\mathrm{Pb}$ accumulates in the bone tissue, where it is deposited in an exchange of $\mathrm{Ca}^{2+}$ ions in biological processes mainly in the less metabolically active cortical bone. Resorbed $\mathrm{Pb}$ is present in the body in two pools: quick change (blood, soft tissue), where it produces acute effects and slow change (bone), which is metabolically inactive. $\mathrm{Pb}$ leads to a decrease in bone mineral density, which is manifested by a greater susceptibility to fractures and bone healing disorders. This is done by altering the metabolism of osteoblasts and osteoclasts, reducing the production of stem cells, osteoblasts, and disorders of calcium homeostasis. The effects on bone cells may be direct (decrease activity of osteoclasts and osteoblasts) or indirect (disturbances in the metabolism of 1.25-dihydroxyvitamin D and parathyroid hormone (PTH)). Lead also competes with the metal binding sites on enzymes, which are cofactors, with zinc in porphobilinogen synthesis or proteins, and with iron in the transfer $[23,24]$.

The main aim of this study was to determine the concentration of $\mathrm{Ca}, \mathrm{Mg}, \mathrm{P}, \mathrm{Na}, \mathrm{K}, \mathrm{Zn}, \mathrm{Cu}, \mathrm{Fe}, \mathrm{Mo}, \mathrm{Cr}, \mathrm{Ni}$, $\mathrm{Ba}, \mathrm{Sr}$, and $\mathrm{Pb}$ in the proximal femoral head (cancellous bone) and femoral neck (cortical bone) of the hip joint affected by osteoarthritis. The present study was conducted to assess differences between the concentrations of metals in the femoral head and neck, according to sex, and also to examine, by statistical and chemometric analysis, a possible correlation between various factors, including: age, place of residence, tobacco consumption, alcohol consumption, contact with chemicals, and the content of elements in the femoral bone. The flame atomic absorption spectrometry (FAAS) and inductively coupled plasma emission spectrometry (ICP-AES) analytical techniques were applied for the determination of elemental metals in bone samples.

\section{Materials and Methods}

2.1. Ethics Statement. The use of femoral heads in the investigations was permitted by the Bioethical Committee of the University of Medical Sciences in Poznan (Poland) (Permit number: 172/4) and all patients provided written informed consent prior to participation.

2.2. Patients. The sample consisted of 96 patients who were operated on for total hip replacement (THR). All patients 
TABLE 1: Information on patients included in the study.

\begin{tabular}{|c|c|c|}
\hline \multirow[t]{2}{*}{ Factors } & \multicolumn{2}{|c|}{ Sample of patients $(n=96)$ who were operated on for total hip replacement (THR) } \\
\hline & & $\mathrm{AM} \pm \mathrm{SD} / \mathrm{Min}$. and $\mathrm{Max}$. \\
\hline \multirow{2}{*}{ Age [years] } & Women $(n=57)$ & $64.5 \pm 14.2 / 25-87$ \\
\hline & Men $(n=39)$ & $63.2 \pm 10.2 / 42-91$ \\
\hline \multirow{2}{*}{ Body weight $[\mathrm{kg}]$} & Women $(n=57)$ & $69.8 \pm 14.2 / 45-115$ \\
\hline & $\operatorname{Men}(n=39)$ & $84 \pm 16.1 / 45-114$ \\
\hline \multirow{2}{*}{ Height $[\mathrm{cm}]$} & Women $(n=57)$ & $159.9 \pm 6.8 / 139-174$ \\
\hline & $\operatorname{Men}(n=39)$ & $172.2 \pm 6.4 / 155-185$ \\
\hline \multirow{3}{*}{ Width of the femur $[\mathrm{cm}]$} & Women $(n=57)$ & $2.98 \pm 0.29 / 2.4-3.7$ \\
\hline & Men $(n=39)$ & $3.31 \pm 0.3 / 2.5-3.8$ \\
\hline & & Number of patients (percent) \\
\hline \multirow{3}{*}{ Place of residence } & Village & $24(25 \%)$ \\
\hline & City $>10000$ & $16(16.7 \%)$ \\
\hline & Town $<10000$ & $56(58.3 \%)$ \\
\hline \multirow{2}{*}{ Type of hip osteoarthritis } & Primary, idiopathic & $54(56.3 \%)$ \\
\hline & Secondary, developmental dysplasia of the hip & $42(43.8 \%)$ \\
\hline \multirow{3}{*}{ Cigarette smoking } & Nonsmoker & $73(76 \%)$ \\
\hline & Irregular smoker & $6(6.3 \%)$ \\
\hline & Regular smoker & $17(17.7 \%)$ \\
\hline \multirow{3}{*}{ Alcohol drinking } & Nondrinker & $46(47.9 \%)$ \\
\hline & Occasionally & $23(24 \%)$ \\
\hline & Often & $27(28.1 \%)$ \\
\hline \multirow{3}{*}{ Physical activity } & During puberty & $60(62.5 \%)$ \\
\hline & Before the disease & $30(31.3 \%)$ \\
\hline & Constant & $23(24 \%)$ \\
\hline \multirow{3}{*}{ Environment pollution } & Air & $5(5.2 \%)$ \\
\hline & Water & $3(3.1 \%)$ \\
\hline & Soil & $2(2.1 \%)$ \\
\hline Contact with chemicals in the workplace & $\begin{array}{l}\text { Type of chemicals: } \\
\text { Fertilizers, plant protection arable, heavy } \\
\text { metals, paints, adhesives, plaster, tannery } \\
\text { articles, photographic chemicals, reagents used } \\
\text { in metallurgy, other chemicals, and detergents }\end{array}$ & $30(31.3 \%)$ \\
\hline
\end{tabular}

lived in the Wielkopolska region of Poland. A history of the disease did not affect the outcome of the study. There is no major industry concentration in this region. Table 1 shows the characteristics of patients enrolled in the study, with particular emphasis on factors that possibly affect the concentration of selected metals in the femoral bone.

\subsection{Characterization and Sampling of Femoral Bone Samples.} All of the femoral heads were acquired intraoperatively from the patients undergoing total hip arthroplasty for osteoarthritis of the hip. In the total hip replacement procedure, a metal ball replaces the worn head of the thigh bone and a cup (often plastic) replaces the worn socket. The shape of the examined proximal ends of the femurs had been changed by the degenerative process. Femoral heads were flattened and bony excrescences could be observed at the head/neck border. Bone tissue condensation at the superolateral part of the femoral head and cysts in femoral head and neck were present. Articular surfaces exhibited defects that were accentuated at the loading area. Articular cartilage was pathologically changed, softened, and disintegrated, with areas of local destruction due to subchondral congestion and blood vessel infiltration. Directly after acquisition, the spongiest bone was separated from the femoral heads under sterile conditions. Samples were cut from the head and neck of the femur. In the case of the femoral neck, samples were collected with a patch section thickness of $1-2 \mathrm{~mm}$ and the $5 \mathrm{~mm}$ slice was taken in the shape of a triangle.

\subsection{Bone Preparation and Determination the Elemental Metals} in Samples. The frozen bone samples were freeze-dried using a Lyovac lyophilizer GT2e (Steris, Germany) for 24 hours. After drying, approximately $0.5 \mathrm{~g}$ of the sample was weighed and placed in a Teflon bomb Mars 5 Xpress microwave oven 
(CEM, USA). A $10 \mathrm{~mL}$ volume of suprapure nitric acid (V) (Merck, Germany) was added. The prepared samples were allowed to stand for 8 hours to slow mineralization. The samples were then mineralized in a microwave oven using a modified EPA method 3051. After cooling, the samples were placed into flasks and filled to $50 \mathrm{~mL}$ with demineralized water. The concentrations of $\mathrm{Mo}, \mathrm{Cr}, \mathrm{Zn}, \mathrm{Pb}, \mathrm{Cu}, \mathrm{Ni}, \mathrm{Fe}$, $\mathrm{Mg}, \mathrm{P}$, and $\mathrm{Ca}$ were determined using ICP-AES Jobin Yvon, 170Ultrace (Jobin Yvon, France) with laterally viewed plasma. The samples were nebulized using a concentric Meinhard nebulizer. The concentrations of $\mathrm{Na}$ and $\mathrm{K}$ were determined using the Shimadzu AA-7000 Flame AAS analytical technique (Shimadzu, Japan). The accuracy of the procedure was verified by analysis of NIST CRM 1400 (Bone Ash) by both analytical techniques. The recoveries for analysed elements varied from $94.6 \%$ to $109 \%$. The limits of detection (LOD) are as follows: Mo $<0.36 \mathrm{mg} / \mathrm{kg} ; \mathrm{Cr}<0.24 \mathrm{mg} / \mathrm{kg}$; $\mathrm{Zn}<0.2 \mathrm{mg} / \mathrm{kg} ; \mathrm{Pb}<0.63 \mathrm{mg} / \mathrm{kg} ; \mathrm{Cu}<0.2 \mathrm{mg} / \mathrm{kg} ; \mathrm{Ni}<$ $0.6 \mathrm{mg} / \mathrm{kg} ; \mathrm{Fe}<0.3 \mathrm{mg} / \mathrm{kg} ; \mathrm{Mg}<0.1 \mathrm{mg} / \mathrm{kg} ; \mathrm{P}<1.0 \mathrm{mg} / \mathrm{kg} ; \mathrm{Ca}$ $<0.1 \mathrm{mg} / \mathrm{kg} ; \mathrm{Na}<0.04 \mathrm{mg} / \mathrm{kg} ; \mathrm{K}<0.6 \mathrm{mg} / \mathrm{kg}$. For statistical and chemometrics analysis, a half value of LOD was used.

2.5. Statistical and Chemometrics Analysis. The analysis used Statistica 7.0 (StatSoft) software. To determine compliance with the expected normal distribution of results, we used a Shapiro-Wilk test $(p<0.05)$. To compare the impact of various environmental factors on the concentration of analysed metals in the bone we used a Kruskal-Wallis test, and, in the case of significant differences, a Mann-Whitney $U$-test was performed $(p<0.05)$. In addition, we determined the Spearman's rank correlation between trace elements occurring in the materials and between the different studied metals in different parts of the hip joint (cortical bone, neck, cancellous bone, head). Principal Component Analysis was used to calculate significant explanatory factor scores for each lake using all physical and chemical variables independently. The environmental factor scores, biomass estimates, and biological variables were compared using correlation analysis.

\section{Results and Discussion}

It is becoming increasingly important to assess the risk to bone tissue from exposure to metals of environmental and occupational origin [25]. The processes of bone remodelling are active throughout the lifespan and therefore can be an indicator of metal accumulation in bone tissue from longterm chronic exposure. The toxic effects may be revealed after many years of exposure or may appear suddenly. Metals may replace other elements necessary for normal metabolism, disrupting a number of processes that depend on the internal equilibrium system $[26,27]$. The largest number of essential correlations between the studied elements occurred in the trabecular bone, followed by cortical bone, and the least number was in the articular cartilage [28]. The trace elements are concentrated in some tissues and organs; their distribution depends on their condition, age, and individual hereditary properties $[29,30]$.
TABLE 2: Concentrations of elements (in $\mathrm{mg} / \mathrm{kg}$ on dry mass basis) and differences between them in the cancellous and cortical bone of the femur $(N=96)$.

\begin{tabular}{|c|c|c|c|}
\hline Metal & $\begin{array}{l}\text { Femoral head } \\
\text { AM } \pm \text { SD } \\
\text { Med. } \\
\text { Min. and Max. }\end{array}$ & $\begin{array}{c}\text { Femoral neck } \\
\text { AM } \pm \text { SD } \\
\text { Med. } \\
\text { Min. and Max. }\end{array}$ & $\mathrm{M}-\mathrm{W}$ \\
\hline & $136705.6 \pm 36168.7$ & $157212.3 \pm 40448.5$ & \\
\hline \multirow[t]{3}{*}{$\mathrm{Ca}$} & 130519 & 153269 & $p<0.01$ \\
\hline & $69364-216920$ & $65524-252100$ & \\
\hline & $62723 \pm 16774.4$ & $70652.3 \pm 18279.3$ & \\
\hline \multirow[t]{3}{*}{$\mathrm{P}$} & 59094.6 & 69616.2 & $p<0.01$ \\
\hline & 33104-98424 & 29480-109180 & \\
\hline & $1446.76 \pm 359.2$ & $1585.8 \pm 320.2$ & \\
\hline \multirow[t]{3}{*}{$\mathrm{Mg}$} & 1381.2 & 1595.3 & $p<0.01$ \\
\hline & $834.3-2528.6$ & 782.9-2243.9 & \\
\hline & $5466.5 \pm 1043.9$ & $4681.2 \pm 884.6$ & \\
\hline \multirow[t]{3}{*}{$\mathrm{Na}$} & 5428.6 & 4662.1 & $p<0.01$ \\
\hline & $3244.2-8566.9$ & 2228.7-6624.7 & \\
\hline & $842.4 \pm 685.7$ & $972.1 \pm 1136.3$ & \\
\hline \multirow[t]{3}{*}{$\mathrm{K}$} & 679.3 & 647.1 & NS \\
\hline & $297-6343.1$ & $250-9340$ & \\
\hline & $72.09 \pm 16$ & $68.7 \pm 13.38$ & \\
\hline \multirow[t]{3}{*}{$\mathrm{Zn}$} & 69.84 & 66.21 & NS \\
\hline & $45.68-112.68$ & $43.06-108.17$ & \\
\hline & $0.91 \pm 0.88$ & $0.89 \pm 1.15$ & \\
\hline \multirow[t]{3}{*}{$\mathrm{Cu}$} & 0.83 & 0.72 & NS \\
\hline & $0.04-3.56$ & $0.04-6.58$ & \\
\hline & $1.33 \pm 2.24$ & $1.44 \pm 1.73$ & \\
\hline \multirow[t]{3}{*}{$\mathrm{Cr}$} & 0.49 & 0.83 & NS \\
\hline & $0.12-14.32$ & $0.12-8.09$ & \\
\hline & $0.6 \pm 1.26$ & $0.79 \pm 2.28$ & \\
\hline \multirow[t]{3}{*}{$\mathrm{Ni}$} & 0.03 & 0.03 & NS \\
\hline & $0.03-7.38$ & $0.03-14.88$ & \\
\hline & $124.42 \pm 106.18$ & $131.52 \pm 139.28$ & \\
\hline \multirow[t]{3}{*}{$\mathrm{Fe}$} & 91.14 & 90.97 & NS \\
\hline & $10.5-499.28$ & $20.63-839.58$ & \\
\hline & $44 \pm 26.5$ & $47.3 \pm 22.7$ & \\
\hline \multirow[t]{3}{*}{$\mathrm{Sr}$} & 36.6 & 43.2 & $p=0.045$ \\
\hline & $1.3-150.9$ & $16.3-137.5$ & \\
\hline & $2.47 \pm 1.68$ & $2.41 \pm 1.3$ & \\
\hline \multirow[t]{3}{*}{$\mathrm{Ba}$} & 2.09 & 2.25 & NS \\
\hline & $0.13-9.05$ & $0.24-7.01$ & \\
\hline & $0.56 \pm 0.6$ & $0.73 \pm 0.68$ & \\
\hline \multirow[t]{3}{*}{ Mo } & 0.18 & 0.18 & $p=0.034$ \\
\hline & $0.18-2.04$ & $0.18-3.1$ & \\
\hline & $1.15 \pm 1.51$ & $1.08 \pm 1.37$ & \\
\hline \multirow[t]{2}{*}{$\mathrm{Pb}$} & 0.32 & 0.32 & NS \\
\hline & $0.32-6.28$ & $0.32-7.52$ & \\
\hline
\end{tabular}

AM: arithmetic mean; SD: standard deviation; Med.: median; Min.: minimal obtained concentration, Max.: maximum obtained concentration; M-W: Mann-Whitney $U$-test; $p$ : level of significance; NS: nonsignificant difference.

The results of the content of the 14 elements in samples of the cancellous and cortical bone of the femur are presented in Table 2. In addition, for the examined group of elements, 
we verified the type of distribution, using the Shapiro-Wilk test. For each element, we also applied the Mann-Whitney $U$-test to determine the significance of difference in the concentrations of elements between the femoral neck and head.

In the case of calcium, the content (as a median value) in the femoral head and neck was $130 \mathrm{~g} / \mathrm{kg}$ and $153 \mathrm{~g} / \mathrm{kg}$, respectively. The obtained concentrations of calcium were much higher in comparison to the report of Kuo et al. [29], in which the concentration of $\mathrm{Ca}$ was $82 \mathrm{~g} / \mathrm{kg}$ in cancellous bone. The phosphorus content in the femoral head and neck was $59 \mathrm{~g} / \mathrm{kg}$ and $69 \mathrm{~g} / \mathrm{kg}$, respectively. The mean content of phosphorus in cancellous bone was comparable to those obtained by Zaichick [31], where the concentration of $\mathrm{P}$ was $56 \mathrm{~g} / \mathrm{kg}$. The concentration of phosphorus in cortical bone was much lower in comparison with Zaichick [31], where the concentration of $\mathrm{P}$ was $107 \mathrm{~g} / \mathrm{kg}$. The content of magnesium in the femoral head and neck was $1381.2 \mathrm{mg} / \mathrm{kg}$ and $1595.3 \mathrm{mg} / \mathrm{kg}$, respectively. The mean content of magnesium was compared to that obtained by Brodziak-Dopierała et al. [28], where the concentration of $\mathrm{Mg}$ was $1650.85 \mathrm{mg} / \mathrm{kg}$ and $1376.14 \mathrm{mg} / \mathrm{kg}$, respectively. In our study, the content of $\mathrm{Mg}$ was higher in cortical bones than in cancellous bone. The median $\mathrm{Na}$ and $\mathrm{K}$ contents in the femoral head and neck were $5428.6 \mathrm{mg} / \mathrm{kg}, 4662.1 \mathrm{mg} / \mathrm{kg}$ and $679.3 \mathrm{mg} / \mathrm{kg}, 647.1 \mathrm{mg} / \mathrm{kg}$, respectively. These were comparable to those reported by Brodziak-Dopierała et al. [28], where the concentrations of $\mathrm{Na}$ were $4745.47 \mathrm{mg} / \mathrm{kg}$ and $6790.35 \mathrm{mg} / \mathrm{kg}$, respectively, and the concentrations of K were $828.80 \mathrm{mg} / \mathrm{kg}$ and $767.11 \mathrm{mg} / \mathrm{kg}$, respectively, in the femoral head and neck. Regarding $\mathrm{Zn}$, Kuo et al. [29] and Darrah [32] found that the content of metal is higher than $100 \mathrm{mg} / \mathrm{kg}$, while in the Polish studies the content of metal was lower $(61.48-94.72 \mathrm{mg} / \mathrm{kg})[28,33$, 34]. In our research, the content of $\mathrm{Zn}$ was approximately $70 \mathrm{mg} / \mathrm{kg}$. The median copper content in the femoral head and neck was $0.83 \mathrm{mg} / \mathrm{kg}$ and $0.72 \mathrm{mg} / \mathrm{kg}$, respectively. The mean concentration of copper in the femur was comparable to the results obtained in cancellous bone by Lanocha et al. [33] $0.67 \mathrm{mg} / \mathrm{kg}$ and Jurkiewicz et al. [34] $0.79 \mathrm{mg} / \mathrm{kg}$. The median iron content in the femur was $91 \mathrm{mg} / \mathrm{kg}$, which was much higher in comparison with Lanocha et al. [33] (cancellous bone $43.9 \mathrm{mg} / \mathrm{kg}$ and cortical bone $40 \mathrm{mg} / \mathrm{kg}$ ) and Jurkiewicz et al. [34] $(47.6 \mathrm{mg} / \mathrm{kg})$ and much lower in comparison with Darrah [32] $(123.35 \mathrm{mg} / \mathrm{kg}$ and $108.15 \mathrm{mg} / \mathrm{kg}$, resp.). In this study, the median chromium content in the femoral head and neck was $0.49 \mathrm{mg} / \mathrm{kg}$ and $0.83 \mathrm{mg} / \mathrm{kg}$, respectively. The median concentration of $\mathrm{Cr}$ was 2 times higher in the femoral head in comparison with Darrah [32] $(0.812 \mathrm{mg} / \mathrm{kg})$ and $10-20$ times lower in the femoral head and neck in comparison with Brodziak-Dopierała et al. [28] $(10.42 \mathrm{mg} / \mathrm{kg}$ and $14.99 \mathrm{mg} / \mathrm{kg}$, resp.). The median barium content in the femoral head and neck was $2.05 \mathrm{mg} / \mathrm{kg}$ and $2.25 \mathrm{mg} / \mathrm{kg}$, respectively. The median concentration of Ba was slightly lower in comparison with Darrah [32] $3.045 \mathrm{mg} / \mathrm{kg}$ and $2.595 \mathrm{mg} / \mathrm{kg}$. The median Mo content in the femoral head and neck was $0.18 \mathrm{mg} / \mathrm{kg}$. The median concentration of molybdenum was 10 times higher in comparison with Darrah [32] (0.013 mg/kg and $0.019 \mathrm{mg} / \mathrm{kg}$, resp.). The mean $\mathrm{Ni}$ content in the femoral head and neck was $0.6 \mathrm{mg} / \mathrm{kg}$ and
$0.79 \mathrm{mg} / \mathrm{kg}$, respectively. The mean concentration of nickel was 10 times lower in comparison to Brodziak-Dopierała et al. [28] in the cancellous and cortical bone $(4.56 \mathrm{mg} / \mathrm{kg}$ and $6.86 \mathrm{mg} / \mathrm{kg}$, resp.). The mean content of toxic lead in the femoral head and neck was $1.15 \mathrm{mg} / \mathrm{kg}$ and $1.08 \mathrm{mg} / \mathrm{kg}$, respectively. The mean concentration of $\mathrm{Pb}$ was 6 and 12 times lower in comparison to Brodziak-Dopierała et al. [28] in the cancellous and cortical bone $(6.22 \mathrm{mg} / \mathrm{kg}$ and $12.27 \mathrm{mg} / \mathrm{kg}$, resp.). The contents of $\mathrm{Pb}$ obtained by Lanocha et al. [33] were 2 times lower $(0.5 \mathrm{mg} / \mathrm{kg})$.

\subsection{Factors Influencing Metal Concentrations in Cancellous} and Cortical Bone. It is well known that interactions between elements can cause disequilibrium in their optimal range of concentrations and, consequently, secondary deficiency or toxicity [28]. The results of this study used various statistical tools and specified the influence of different environmental factors on the occurrence and content of 14 elements in the femoral bone. Distributions of macroelement concentrations $(\mathrm{Ca}, \mathrm{P}, \mathrm{Mg}$, and $\mathrm{Na}$ ) in the femoral neck had the characteristics of a normal distribution and in the case of femoral head the same type of distribution was observed for $\mathrm{Mg}$ and $\mathrm{Na}$, which was confirmed by the Shapiro-Wilk test. We found that, in the femoral neck, macroelement concentrations (Ca, $\mathrm{P}$, and $\mathrm{Mg}$ ) and two trace element concentrations ( $\mathrm{Sr}, \mathrm{Cr}$ ) were significantly higher than those in femoral head (Table 2). The Spearman's rank correlation allowed us to determine the relationships between examined metals in the bones of the patients (Table 3).

Strong and very strong correlations were found between $\mathrm{Ca}, \mathrm{P}, \mathrm{Mg}, \mathrm{Na}$, and $\mathrm{Zn}$ for the femoral head and neck. A moderate correlation was found between two metals, $\mathrm{Sr}$ and $\mathrm{Ba}$, and between them and the $\mathrm{Ca}, \mathrm{P}, \mathrm{Mg}, \mathrm{Na}$, and $\mathrm{Zn}$ for the femoral head and neck. Other correlations for the femoral head and neck were $\mathrm{Fe} / \mathrm{Cr}, \mathrm{Cu} / \mathrm{Ni}$, and $\mathrm{Cu} / \mathrm{Zn}$, those only for the femoral neck were $\mathrm{Cu} / \mathrm{Fe}$ and $\mathrm{Mo} / \mathrm{Pb}$, and only for femoral head were $\mathrm{Mo}$ and $\mathrm{Cu}$. Weak correlations were found between $\mathrm{Pb}$ and the macroelements $\mathrm{Ca}, \mathrm{P}, \mathrm{Mg}$, and $\mathrm{Na}$ for the femoral neck.

The changes between the femoral head and neck were analysed by PCA chemometric technique. For the 6 important components, the total variance was $79.1 \%$ in the femoral neck and $77.4 \%$ in the femoral head (Figure 1).

In femoral neck and head, the first component represents the change of the contents of $\mathrm{Ca}, \mathrm{P}, \mathrm{Na}, \mathrm{Mg}$, and $\mathrm{Zn}$. In the femoral head, only the first component indicates the meaning of the $\mathrm{Ba}$. The second factor describes the changes of content of $\mathrm{Cu}, \mathrm{Ni}$. In case of $\mathrm{Cr}$, the second component for the femoral head and the third component for the femoral neck concerns the role of element content. In the case of $\mathrm{Fe}$ content, the meaning is indicated by the third component in both parts. The meaning of $\mathrm{Ba}$ content is indicated by the fifth component in the femoral neck. The fourth and fifth components for the femoral head and the sixth component for the femoral neck concern the role of $\mathrm{Pb}$ content.

3.1.1. Sex. To determine the differences in the content of various elements in the femur samples between women 
TABLE 3: Spearman correlation coefficients for metals found in femoral neck and head for all samples.

\begin{tabular}{|c|c|c|c|c|c|c|c|c|c|c|c|c|c|c|c|}
\hline & $\begin{array}{c}\text { Mo } \\
\text { Head }\end{array}$ & $\mathrm{Cr}$ & $\mathrm{Zn}$ & $\mathrm{Pb}$ & $\mathrm{Cu}$ & $\mathrm{Ni}$ & $\mathrm{Fe}$ & $\mathrm{Mg}$ & K & $\mathrm{P}$ & $\mathrm{Sr}$ & $\mathrm{Ba}$ & $\mathrm{Na}$ & $\mathrm{Ca}$ & Age \\
\hline Mo & $\mathrm{x}$ & -0.08 & 0.09 & 0.02 & 0.22 & -0.10 & 0.05 & 0.07 & 0.07 & 0.08 & 0.04 & -0.01 & -0.13 & 0.03 & 0.02 \\
\hline $\mathrm{Cr}$ & 0.11 & $\mathrm{x}$ & -0.03 & -0.16 & $0.43^{*}$ & 0.16 & $0.34^{*}$ & 0.07 & 0.19 & 0.05 & -0.09 & 0.06 & 0.13 & 0.02 & 0.03 \\
\hline $\mathrm{Zn}$ & -0.13 & -0.07 & $\mathrm{x}$ & 0.08 & -0.09 & -0.13 & 0.14 & $0.80^{*}$ & 0.11 & $0.81^{*}$ & $0.52^{*}$ & $0.40^{*}$ & $0.46^{*}$ & $0.79^{*}$ & -0.11 \\
\hline $\mathrm{Pb}$ & $-0.32^{*}$ & -0.18 & $0.26^{*}$ & $\mathrm{x}$ & -0.01 & -0.02 & 0.03 & 0.06 & 0.02 & 0.01 & -0.05 & 0.06 & 0.20 & 0.05 & 0.10 \\
\hline $\mathrm{Cu}$ & -0.17 & $0.27^{*}$ & -0.12 & 0.12 & $\mathrm{x}$ & $0.44^{*}$ & 0.15 & -0.05 & $0.21^{*}$ & -0.14 & -0.08 & -0.13 & 0.03 & -0.14 & 0.04 \\
\hline $\mathrm{Ni}$ & -0.03 & $0.31^{*}$ & -0.16 & 0.01 & $0.57^{*}$ & $\mathrm{x}$ & -0.18 & -0.14 & $-0.29^{*}$ & -0.14 & -0.07 & 0.04 & -0.20 & -0.15 & 0.02 \\
\hline $\mathrm{Fe}$ & -0.02 & $0.37^{*}$ & -0.18 & -0.12 & $0.34^{*}$ & 0.14 & $\mathrm{x}$ & 0.05 & $0.30^{*}$ & 0.09 & -0.03 & -0.03 & 0.12 & 0.04 & 0.13 \\
\hline $\mathrm{Mg}$ & -0.16 & -0.09 & $0.74^{*}$ & $0.27^{*}$ & $-0.25^{*}$ & $-0.28^{*}$ & -0.18 & $\mathrm{x}$ & 0.19 & $0.92^{*}$ & $0.58^{*}$ & $0.48^{*}$ & $0.39^{*}$ & $0.89^{*}$ & -0.11 \\
\hline K & -0.02 & $0.26^{*}$ & 0.00 & -0.10 & 0.01 & -0.03 & $0.28^{*}$ & -0.12 & $\mathrm{x}$ & 0.12 & $0.26^{*}$ & -0.05 & $0.45^{*}$ & 0.07 & 0.08 \\
\hline $\mathrm{P}$ & -0.10 & -0.20 & $0.63^{*}$ & $0.21^{*}$ & $-0.39^{*}$ & $-0.39^{*}$ & $-0.22^{*}$ & $0.89^{*}$ & -0.19 & $\mathrm{x}$ & $0.55^{*}$ & $0.47^{*}$ & $0.40^{*}$ & $0.97^{*}$ & -0.13 \\
\hline $\mathrm{Sr}$ & -0.04 & -0.06 & $0.37^{*}$ & 0.10 & -0.16 & 0.03 & $-0.20^{*}$ & $0.42^{*}$ & -0.03 & $0.40^{*}$ & $\mathrm{x}$ & $0.39^{*}$ & $0.36^{*}$ & $0.55^{*}$ & -0.08 \\
\hline $\mathrm{Ba}$ & 0.03 & -0.07 & $0.23^{*}$ & 0.01 & -0.20 & -0.16 & -0.13 & $0.37^{*}$ & -0.17 & $0.34^{*}$ & $0.32^{*}$ & $\mathrm{x}$ & $0.22^{*}$ & $0.43^{*}$ & -0.05 \\
\hline $\mathrm{Na}$ & -0.06 & -0.10 & $0.65^{*}$ & $0.24^{*}$ & $-0.26^{*}$ & $-0.26^{*}$ & -0.04 & $0.79^{*}$ & 0.10 & $0.80^{*}$ & $0.41^{*}$ & $0.22^{*}$ & $\mathrm{x}$ & $0.36^{*}$ & -0.10 \\
\hline $\mathrm{Ca}$ & -0.08 & -0.15 & $0.62^{*}$ & $0.22^{*}$ & $-0.36^{*}$ & $-0.32^{*}$ & -0.18 & $0.86^{*}$ & -0.17 & $0.96^{*}$ & $0.38^{*}$ & $0.31^{*}$ & $0.76^{*}$ & $\mathrm{x}$ & -0.11 \\
\hline Age & 0.00 & 0.05 & $-0.22^{*}$ & 0.10 & 0.17 & 0.02 & 0.08 & $-0.28^{*}$ & 0.11 & $-0.29^{*}$ & $-0.30^{*}$ & -0.19 & $-0.22^{*}$ & $-0.29^{*}$ & $\mathrm{x}$ \\
\hline
\end{tabular}

${ }^{*}$ Statistically significant.

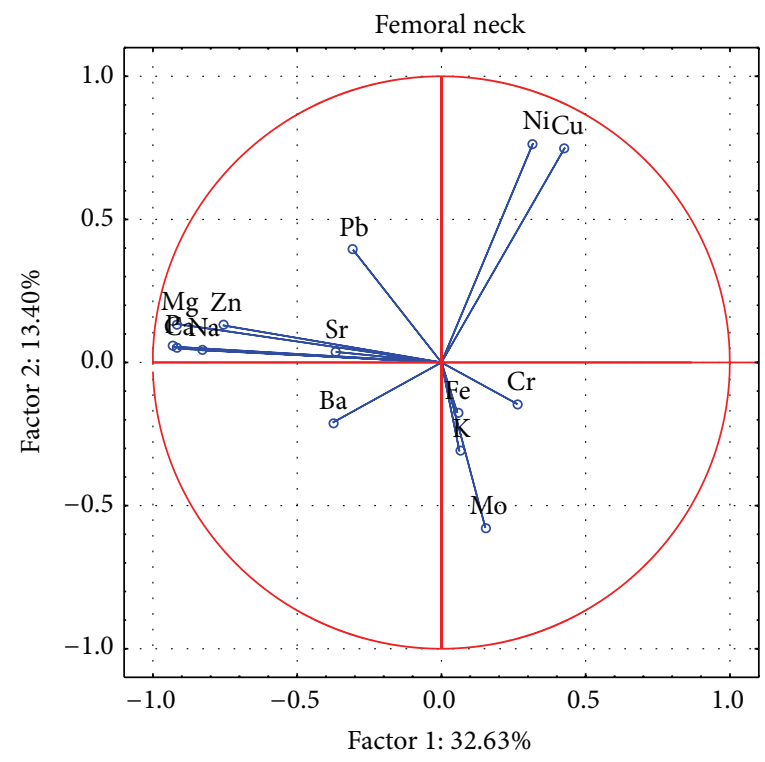

- Active

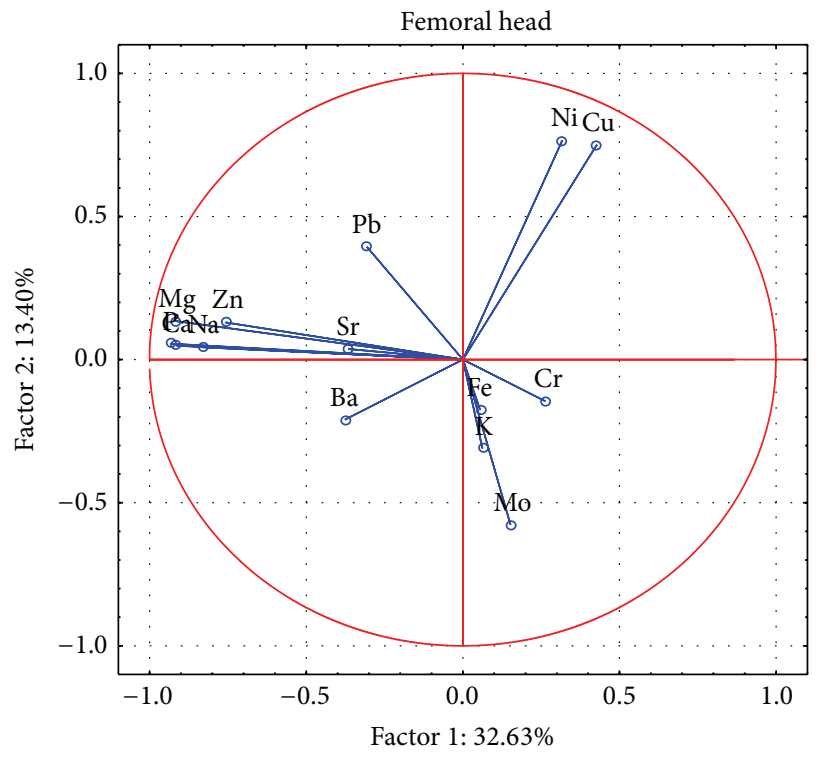

- Active

FIgURE 1: A graphic illustration of Principal Components Analysis. Projection of the variables on the factor plane of the first two principal components for femoral head and neck for all samples.

and men, the Mann-Whitney test was used (Table 4). The differences in 4 metal contents in the femoral heads of women were statistically significant $(p<0.05)$ from those of men. Higher contents of $\mathrm{Cu}, \mathrm{Ni}, \mathrm{Zn}$, and $\mathrm{Pb}$ were found in the femoral heads of men than in women. Brodziak-Dopierała et al. $[13,22]$ found that the content of $\mathrm{Ni}$ and $\mathrm{Fe}$ in the femoral head in men was higher than in women. The present study supports these findings. S. Zaichick and V. Zaichick [35] found higher $\mathrm{Ca}, \mathrm{K}, \mathrm{Mg}, \mathrm{Na}$, and $\mathrm{Sr}$ mass fractions in female femoral necks compared with male femoral necks, while Budis et al. [18] found that the concentrations of Fe and $\mathrm{Sr}$ were similar in men and women. In our study, more correlations were observed for men than for women.

Comparisons between male and female femoral necks showed negative correlations for $\mathrm{Cu} / \mathrm{Zn}, \mathrm{Mo} / \mathrm{Pb}$, and $\mathrm{Cu} / \mathrm{Mo}$ and positive correlations for $\mathrm{Cr} / \mathrm{Ni}$ and $\mathrm{Cr} / \mathrm{Fe}$. The comparison between the femoral necks of women and men showed positive correlations of $\mathrm{Pb}$ to $\mathrm{Ca}, \mathrm{P}, \mathrm{Mg}$, and $\mathrm{Na}$ only for the 
TABLE 4: Concentrations of elements (in $\mathrm{mg} / \mathrm{kg}$ on dry mass basis) and differences between them in the cancellous and cortical bone of the femur according to sex $(N=96)$.

\begin{tabular}{|c|c|c|c|c|c|c|}
\hline & & Femoral head & & & moral neck & \\
\hline & & $\mathrm{AM} \pm \mathrm{SD}$ & & & $\mathrm{AM} \pm \mathrm{SD}$ & \\
\hline & & Med. & & & Med. & \\
\hline & & QL-QU & & & QL-QU & \\
\hline & $\operatorname{Men}(n=39)$ & Women $(n=57)$ & M-W & Men $(n=39)$ & Women $(n=57)$ & M-W \\
\hline & $142503 \pm 36420$ & $132738 \pm 35772$ & & $154831 \pm 43196$ & $158841 \pm 38764$ & \\
\hline $\mathrm{Ca}$ & 139422 & 122400 & NS & 153224 & 156350 & NS \\
\hline & $108142-174294$ & 104630-158906 & & $125302-181456$ & 125986-186928 & \\
\hline & $65624 \pm 16587$ & $60738 \pm 16755$ & & $69124 \pm 19596$ & $71697 \pm 17421$ & \\
\hline $\mathrm{P}$ & 65522 & 55350.5 & NS & 70672.4 & 68560 & NS \\
\hline & 50535.9-79484 & $47526.7-72451$ & & $55192.08-82266$ & 57827.5-84699 & \\
\hline & $1492.9 \pm 344.5$ & $1415.2 \pm 368.5$ & & $1566.1 \pm 345.1$ & $1599.3 \pm 304.5$ & \\
\hline $\mathrm{Mg}$ & 1533.8 & 1335.6 & NS & 1593.8 & 1606.9 & NS \\
\hline & $1205.1-1784.7$ & 1112.9-1644.6 & & $1283.2-1793.7$ & 1382.9-1790.4 & \\
\hline & $5522.7 \pm 1096.3$ & $5428 \pm 1014.7$ & & $4617.7 \pm 1025.9$ & $4724.7 \pm 780.2$ & \\
\hline $\mathrm{Na}$ & 5765.7 & 5399.5 & NS & 4628.4 & 4719 & NS \\
\hline & 4627.7-6308.9 & $4772.7-5824.5$ & & $3717.3-5343.6$ & $4126.5-5223.4$ & \\
\hline & $677.3 \pm 260.7$ & $955.3 \pm 848.3$ & & $775 \pm 791.1$ & $1107 \pm 1311.5$ & \\
\hline $\mathrm{K}$ & 584.91 & 780 & $<0.05$ & 570 & 792.08 & $<0.01$ \\
\hline & $490-840$ & $570-1049.5$ & & $435.64-934.58$ & $600-1168.32$ & \\
\hline & $76.75 \pm 15.37$ & $68.91 \pm 15.77$ & & $69.63 \pm 13.37$ & $68.07 \pm 13.46$ & \\
\hline $\mathrm{Zn}$ & 76.25 & 64.54 & $<0.05$ & 69.52 & 64.27 & NS \\
\hline & $66.42-89.45$ & $56.53-79.47$ & & $58.76-75.45$ & $58.53-76.86$ & \\
\hline & $1.16 \pm 1$ & $0.74 \pm 0.75$ & & $0.97 \pm 1.25$ & $0.83 \pm 1.09$ & \\
\hline $\mathrm{Cu}$ & 1.07 & 0.64 & $<0.05$ & 0.8 & 0.58 & NS \\
\hline & $0.04-1.77$ & $0.04-1.14$ & & $0.04-1.44$ & $0.04-1.1$ & \\
\hline & $1.34 \pm 2.47$ & $1.33 \pm 2.1$ & & $1.18 \pm 1.33$ & $1.62 \pm 1.95$ & \\
\hline $\mathrm{Cr}$ & 0.61 & 0.44 & NS & 0.89 & 0.76 & NS \\
\hline & $0.12-1.41$ & $0.12-1.69$ & & $0.12-1.44$ & $0.12-2.28$ & \\
\hline & $0.88 \pm 1.6$ & $0.41 \pm 0.93$ & & $0.99 \pm 2.62$ & $0.64 \pm 2.03$ & \\
\hline $\mathrm{Ni}$ & 0.21 & 0.03 & $<0.05$ & 0.03 & 0.03 & NS \\
\hline & $0.03-0.94$ & $0.03-0.39$ & & $0.03-0.96$ & $0.03-0.41$ & \\
\hline & $131.01 \pm 114.31$ & $119.91 \pm 101.04$ & & $111.75 \pm 86.48$ & $145.04 \pm 165.46$ & \\
\hline $\mathrm{Fe}$ & 96.44 & 89.82 & NS & 80.77 & 93.52 & NS \\
\hline & $46.04-178.11$ & $58.98-128.07$ & & $50.35-141.99$ & $56.73-164.58$ & \\
\hline & $45.22 \pm 30.76$ & $43.14 \pm 23.31$ & & $47.24 \pm 26.88$ & $47.28 \pm 19.58$ & \\
\hline $\mathrm{Sr}$ & 39.89 & 36.29 & NS & 42.31 & 44.87 & NS \\
\hline & $26.16-48.57$ & $25.96-50.38$ & & $29.27-49.86$ & $33.54-56.15$ & \\
\hline & $0.44 \pm 0.51$ & $0.65 \pm 0.64$ & & $0.8 \pm 0.74$ & $0.69 \pm 0.64$ & \\
\hline Mo & 0.18 & 0.18 & NS & 0.39 & 0.18 & NS \\
\hline & $0.18-0.18$ & $0.18-1.32$ & & $0.18-1.42$ & $0.18-1.33$ & \\
\hline & $2.64 \pm 1.58$ & $2.35 \pm 1.74$ & & $2.51 \pm 1.24$ & $2.34 \pm 1.35$ & \\
\hline $\mathrm{Ba}$ & 2.28 & 1.98 & NS & 2.47 & 1.99 & NS \\
\hline & $1.66-3.33$ & $1.34-2.8$ & & $1.4-3.49$ & $1.33-3.11$ & \\
\hline & $1.57 \pm 1.7$ & $0.86 \pm 1.31$ & & $1.41 \pm 1.65$ & $0.85 \pm 1.1$ & \\
\hline $\mathrm{Pb}$ & 0.32 & 0.32 & $<0.05$ & 0.32 & 0.32 & NS \\
\hline & $0.32-2.8$ & $0.32-0.32$ & & $0.32-2.12$ & $0.32-1.15$ & \\
\hline
\end{tabular}

AM: arithmetic mean; SD: standard deviation; Med.: median; QL: lower quartile; QU: upper quartile; M-W: Mann-Whitney U-test; $p$ : level of significance; NS: nonsignificant difference. 
TABLE 5: Spearman correlation coefficients for metals found in femoral neck by sex.

\begin{tabular}{|c|c|c|c|c|c|c|c|c|c|c|c|c|c|c|c|}
\hline Neck & $\begin{array}{c}\text { Mo } \\
\text { Women }\end{array}$ & $\mathrm{Cr}$ & $\mathrm{Zn}$ & $\mathrm{Pb}$ & $\mathrm{Cu}$ & $\mathrm{Ni}$ & $\mathrm{Fe}$ & $\mathrm{Mg}$ & K & $\mathrm{P}$ & $\mathrm{Sr}$ & $\mathrm{Ba}$ & $\mathrm{Na}$ & $\mathrm{Ca}$ & Age \\
\hline Mo & $\mathrm{x}$ & 0.04 & -0.11 & 0.25 & $-0.40^{*}$ & -0.06 & -0.08 & -0.05 & -0.13 & -0.03 & 0.08 & 0.24 & -0.09 & 0.01 & -0.15 \\
\hline $\mathrm{Cr}$ & 0.14 & $\mathrm{x}$ & 0.06 & -0.10 & 0.25 & $0.37^{*}$ & $0.49^{*}$ & 0.06 & 0.16 & -0.04 & 0.00 & 0.05 & 0.07 & 0.00 & -0.02 \\
\hline $\mathrm{Zn}$ & -0.15 & -0.26 & $\mathrm{x}$ & 0.11 & 0.12 & -0.12 & -0.13 & $0.72^{*}$ & 0.01 & $0.56^{*}$ & $0.29^{*}$ & 0.23 & $0.57^{*}$ & $0.54^{*}$ & -0.22 \\
\hline $\mathrm{Pb}$ & $-0.44^{*}$ & -0.31 & $0.43^{*}$ & $\mathrm{x}$ & 0.15 & 0.05 & -0.08 & 0.05 & -0.08 & -0.04 & -0.14 & -0.15 & 0.09 & -0.03 & 0.23 \\
\hline $\mathrm{Cu}$ & 0.00 & 0.25 & $-0.42^{*}$ & 0.07 & $\mathrm{x}$ & $0.54^{*}$ & $0.50^{*}$ & -0.10 & 0.10 & $-0.27^{*}$ & -0.03 & -0.21 & -0.15 & -0.25 & 0.11 \\
\hline $\mathrm{Ni}$ & -0.09 & 0.19 & -0.24 & -0.09 & $0.59^{*}$ & $\mathrm{x}$ & $0.33^{*}$ & -0.19 & 0.08 & $-0.30^{*}$ & -0.10 & -0.18 & -0.15 & -0.22 & 0.00 \\
\hline $\mathrm{Fe}$ & 0.10 & 0.22 & -0.24 & -0.17 & 0.14 & -0.10 & $\mathrm{x}$ & -0.18 & $0.27^{*}$ & -0.25 & -0.05 & -0.16 & -0.02 & -0.18 & 0.09 \\
\hline $\mathrm{Mg}$ & -0.27 & -0.26 & $0.80^{*}$ & $0.59^{*}$ & $-0.44^{*}$ & $-0.41^{*}$ & -0.17 & $\mathrm{x}$ & -0.17 & $0.88^{*}$ & $0.35^{*}$ & $0.44^{*}$ & $0.78^{*}$ & $0.83^{*}$ & -0.25 \\
\hline $\mathrm{K}$ & 0.10 & $0.43^{*}$ & -0.02 & -0.06 & -0.02 & -0.04 & 0.27 & -0.15 & $\mathrm{x}$ & -0.26 & -0.01 & -0.07 & 0.05 & -0.21 & -0.11 \\
\hline $\mathrm{P}$ & -0.12 & $-0.35^{*}$ & $0.76^{*}$ & $0.56^{*}$ & $-0.51^{*}$ & $-0.49^{*}$ & -0.15 & $0.91^{*}$ & -0.22 & $\mathrm{x}$ & $0.35^{*}$ & $0.42^{*}$ & $0.78^{*}$ & $0.94^{*}$ & $-0.29^{*}$ \\
\hline Sr & -0.11 & -0.11 & $0.48^{*}$ & $0.39^{*}$ & -0.31 & 0.17 & $-0.36^{*}$ & $0.50^{*}$ & -0.11 & $0.47^{*}$ & $\mathrm{x}$ & $0.43^{*}$ & $0.38^{*}$ & $0.30^{*}$ & $-0.32^{*}$ \\
\hline $\mathrm{Ba}$ & -0.21 & -0.24 & 0.24 & 0.17 & -0.20 & -0.19 & -0.06 & 0.28 & -0.28 & 0.22 & 0.19 & $\mathrm{x}$ & $0.34^{*}$ & $0.38^{*}$ & -0.19 \\
\hline $\mathrm{Na}$ & 0.01 & -0.25 & $0.78^{*}$ & $0.44^{*}$ & $-0.38^{*}$ & $-0.39^{*}$ & -0.06 & $0.81^{*}$ & 0.06 & $0.83^{*}$ & $0.48^{*}$ & 0.12 & $\mathrm{x}$ & $0.74^{*}$ & -0.24 \\
\hline $\mathrm{Ca}$ & -0.12 & -0.29 & $0.79^{*}$ & $0.53^{*}$ & $-0.48^{*}$ & $-0.43^{*}$ & -0.17 & $0.91^{*}$ & -0.22 & $0.98^{*}$ & $0.49^{*}$ & 0.22 & $0.81^{*}$ & $\mathrm{x}$ & -0.25 \\
\hline Age & 0.21 & 0.13 & -0.23 & 0.01 & $0.32^{*}$ & 0.09 & 0.12 & $-0.39^{*}$ & $0.35^{*}$ & $-0.34^{*}$ & -0.31 & -0.16 & -0.23 & $-0.40^{*}$ & $\mathrm{x}$ \\
\hline & Men & & & & & & & & & & & & & & \\
\hline
\end{tabular}

* Statistically significant.

TABLE 6: Spearman correlation coefficients for metals found in femoral head by sex.

\begin{tabular}{|c|c|c|c|c|c|c|c|c|c|c|c|c|c|c|c|}
\hline Head & $\begin{array}{c}\text { Mo } \\
\text { Women }\end{array}$ & $\mathrm{Cr}$ & $\mathrm{Zn}$ & $\mathrm{Pb}$ & $\mathrm{Cu}$ & $\mathrm{Ni}$ & $\mathrm{Fe}$ & $\mathrm{Mg}$ & $\mathrm{K}$ & $\mathrm{P}$ & $\mathrm{Sr}$ & $\mathrm{Ba}$ & $\mathrm{Na}$ & $\mathrm{Ca}$ & Age \\
\hline Mo & $\mathrm{x}$ & -0.13 & 0.11 & 0.15 & $-0.32^{*}$ & 0.08 & -0.03 & 0.04 & -0.12 & 0.03 & 0.00 & 0.00 & -0.28 & 0.03 & -0.07 \\
\hline $\mathrm{Cr}$ & 0.09 & $\mathrm{x}$ & -0.09 & -0.15 & $0.39^{*}$ & 0.21 & $0.27^{*}$ & 0.06 & 0.10 & 0.02 & -0.13 & 0.09 & 0.24 & 0.00 & 0.04 \\
\hline $\mathrm{Zn}$ & $0.35^{*}$ & -0.04 & $\mathrm{x}$ & -0.02 & -0.07 & -0.01 & 0.14 & $0.75^{*}$ & 0.12 & $0.78^{*}$ & $0.48^{*}$ & $0.42^{*}$ & $0.42^{*}$ & $0.80^{*}$ & -0.13 \\
\hline $\mathrm{Pb}$ & -0.05 & -0.16 & 0.03 & $\mathrm{x}$ & -0.12 & 0.02 & 0.01 & -0.09 & -0.02 & -0.06 & -0.10 & 0.00 & -0.08 & -0.02 & 0.11 \\
\hline $\mathrm{Cu}$ & -0.02 & $0.57^{*}$ & $-0.35^{*}$ & -0.10 & $\mathrm{x}$ & $0.28^{*}$ & 0.13 & 0.04 & $0.41^{*}$ & -0.06 & -0.07 & -0.16 & 0.24 & -0.07 & 0.07 \\
\hline $\mathrm{Ni}$ & -0.25 & 0.20 & $-0.49^{*}$ & -0.15 & $0.51^{*}$ & $\mathrm{x}$ & -0.14 & 0.03 & -0.22 & 0.06 & 0.04 & 0.05 & -0.07 & 0.07 & 0.06 \\
\hline $\mathrm{Fe}$ & 0.20 & $0.36^{*}$ & 0.15 & 0.08 & 0.16 & -0.25 & $\mathrm{x}$ & 0.02 & 0.17 & 0.06 & 0.03 & -0.07 & 0.06 & 0.04 & $0.35^{*}$ \\
\hline $\mathrm{Mg}$ & 0.24 & 0.06 & $0.85^{*}$ & 0.08 & -0.26 & $-0.42^{*}$ & 0.10 & $\mathrm{x}$ & 0.21 & $0.90^{*}$ & $0.59^{*}$ & $0.54^{*}$ & $0.42^{*}$ & $0.89^{*}$ & -0.18 \\
\hline K & $0.34^{*}$ & 0.25 & $0.35^{*}$ & 0.21 & 0.09 & -0.29 & $0.50^{*}$ & $0.33^{*}$ & $\mathrm{x}$ & 0.12 & 0.23 & 0.03 & $0.46^{*}$ & 0.09 & 0.00 \\
\hline $\mathrm{P}$ & $0.32^{*}$ & 0.05 & $0.84^{*}$ & -0.07 & $-0.34^{*}$ & $-0.52^{*}$ & 0.16 & $0.93^{*}$ & $0.34^{*}$ & $\mathrm{x}$ & $0.59^{*}$ & $0.56^{*}$ & $0.43^{*}$ & $0.99^{*}$ & -0.20 \\
\hline $\mathrm{Sr}$ & 0.16 & -0.06 & $0.57^{*}$ & -0.07 & -0.07 & -0.18 & -0.10 & $0.56^{*}$ & $0.44^{*}$ & $0.52^{*}$ & $\mathrm{x}$ & $0.49^{*}$ & $0.38^{*}$ & $0.58^{*}$ & -0.18 \\
\hline $\mathrm{Ba}$ & 0.06 & -0.05 & 0.18 & 0.06 & -0.18 & 0.02 & 0.00 & 0.25 & -0.05 & 0.22 & 0.22 & $\mathrm{x}$ & $0.32^{*}$ & $0.53^{*}$ & -0.10 \\
\hline $\mathrm{Na}$ & 0.10 & -0.08 & $0.38^{*}$ & $0.45^{*}$ & -0.25 & $-0.37^{*}$ & 0.21 & 0.29 & $0.54^{*}$ & 0.31 & 0.29 & 0.03 & $\mathrm{x}$ & $0.40^{*}$ & $-0.30^{*}$ \\
\hline $\mathrm{Ca}$ & 0.18 & 0.01 & $0.78^{*}$ & 0.02 & $-0.32^{*}$ & $-0.50^{*}$ & 0.05 & $0.87^{*}$ & 0.22 & $0.92^{*}$ & $0.52^{*}$ & 0.18 & 0.23 & $\mathrm{x}$ & -0.19 \\
\hline Age & 0.16 & 0.00 & 0.03 & 0.16 & 0.06 & 0.07 & -0.15 & 0.06 & 0.20 & 0.12 & 0.12 & 0.10 & 0.14 & 0.17 & $\mathrm{x}$ \\
\hline
\end{tabular}

* Statistically significant.

men. The greatest divergence of the correlation coefficient in the head of the femur between women and men was observed in the case of $\mathrm{Na}$. All correlations between metals according to the sex in the femoral neck and head are presented in Tables 5 and 6.

Conducting the PCA showed that the changes between women and men are described by 6 important components, the total variance of which is $79.1 \%$ in the femoral neck and $77.4 \%$ in the femoral head (Figures 2-3).

In the femoral neck and head, the first component represents the change of the contents of $\mathrm{Ca}, \mathrm{P}, \mathrm{Na}, \mathrm{Mg}$, and
$\mathrm{Zn}$. In the femoral neck, the first component indicates the meaning of the $\mathrm{Pb}$ only in men. The second factor defines the changes of content of $\mathrm{Cu}, \mathrm{Ni}, \mathrm{Mo}$, and $\mathrm{Cr}$ in women as well as in men. The meaning of Ba content in the femoral neck and head is indicated by the third component only in men. The third component for women and men concerns the role of Fe content. The meaning of $\mathrm{K}$ was represented by the fourth component for women and the fifth component for men. The fourth component for men and the fifth component in both concern the role of $\mathrm{Pb}$ content in the femoral head. The meaning of $\mathrm{K}$ was represented by the fifth and 


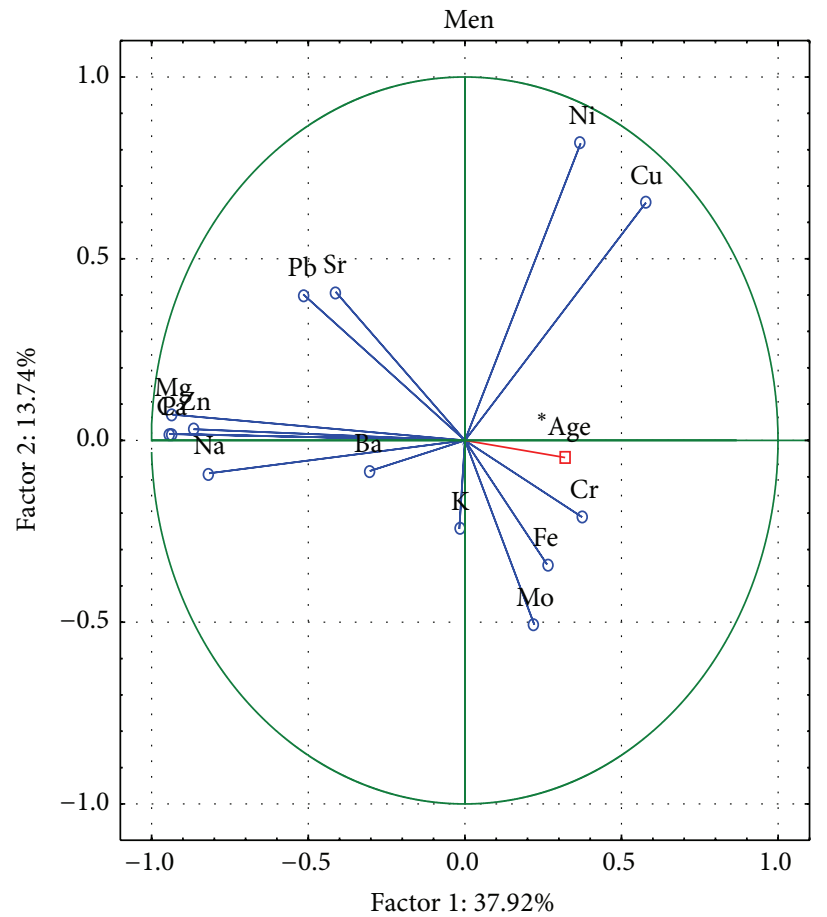

- Active

$\square$ Add.

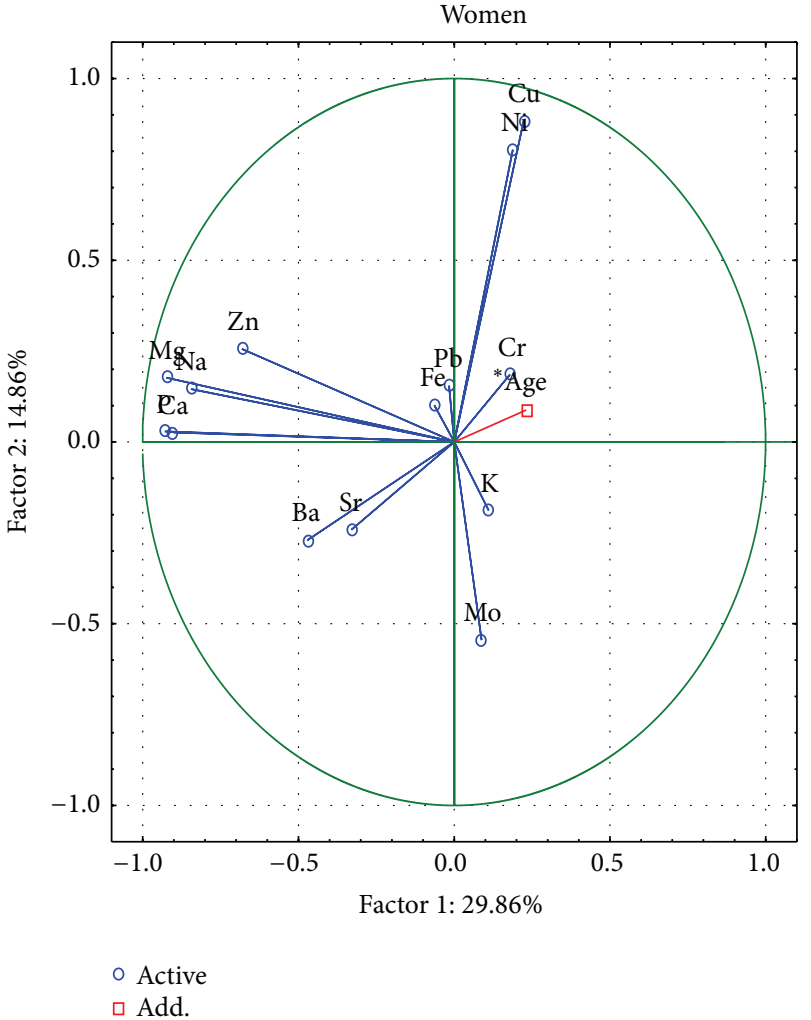

$\square$ Add.

Figure 2: A graphic illustration of Principal Components Analysis of contents of elements according to sex for femoral neck. Projection of the variables on the factor plane of the first two principal components for men and women.

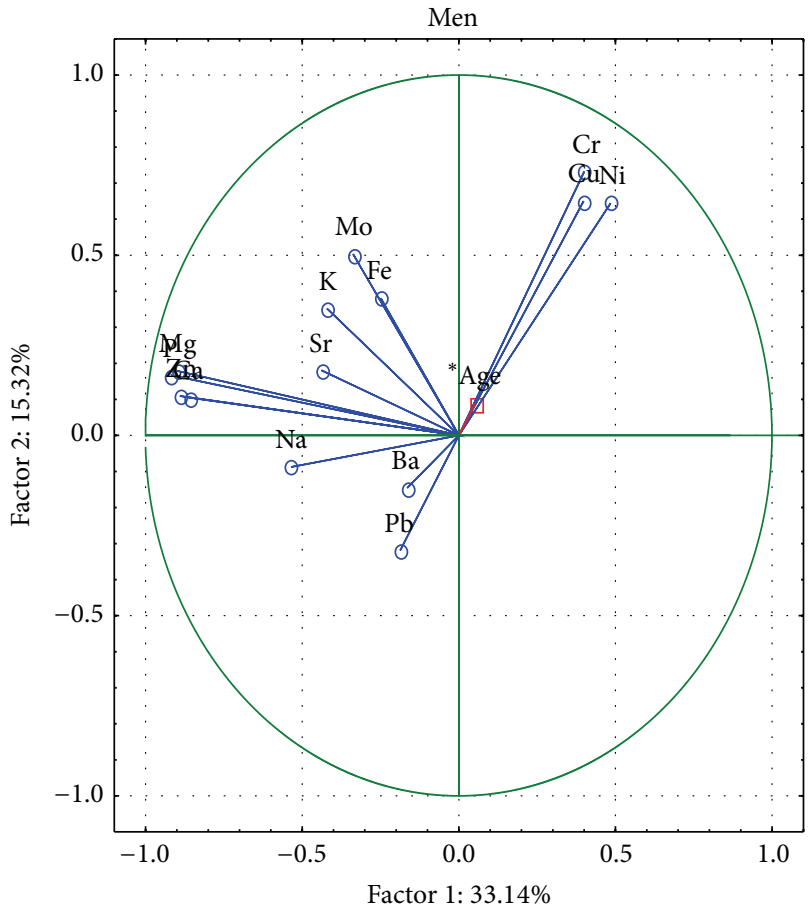

O Active

$\square$ Add.

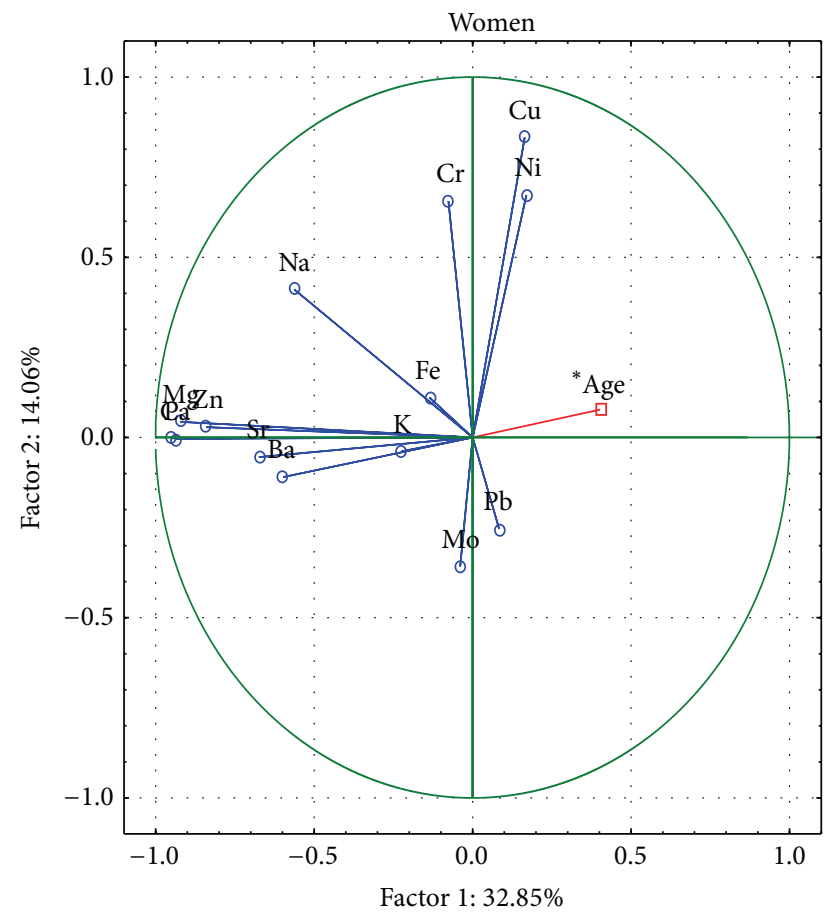

$O$ Active

$\square$ Add.

Figure 3: A graphic illustration of Principal Components Analysis of contents of elements according to sex for femoral head. Projection of the variables on the factor plane of the first two principal components for men and women. 
sixth components for women and the third component for men in the femoral head. The comparison with the PCA conducted by Brodziak-Dopierała et al. [27] showed that the first component of their data was represented by the change of the contents of $\mathrm{Cr}, \mathrm{Ni}, \mathrm{Zn}, \mathrm{Na}, \mathrm{Ca}$, and $\mathrm{Cu}$, and, in the second order, there are changes of content of $\mathrm{Mn}, \mathrm{Cd}, \mathrm{Pb}$, and $\mathrm{Fe}$, regardless of gender. It is important to note that only the fifth component concerns the role of $\mathrm{Mg}$ content. The present data [27] are contrary to this study in which the first factor described structural elements.

It should be emphasized that the results proved that sex is a major factor that determines the type of interaction of metals with elements of physiological importance [36]. According to the literature, the majority of trace elements are not significantly different between the bones of male and female patients, with the exception of $\mathrm{Zn}$ in trabecular tissues and $\mathrm{Pb}$ in cortical tissues of men [37, 38]. This statement contradicts our findings, which showed apparent differences in the femoral head for $\mathrm{Zn}, \mathrm{Pb}, \mathrm{Cu}$, and $\mathrm{Ni}$ for both genders. Brodziak-Dopierała et al. [28] found in both men and women statistically significant correlations between the concentrations of $\mathrm{Cr}-\mathrm{Ni}, \mathrm{Cr}-\mathrm{Na}, \mathrm{Ni}-\mathrm{Cd}$, and $\mathrm{Ni}-\mathrm{Cu}$, and in $\mathrm{Zn}-\mathrm{Na}, \mathrm{Ca}-\mathrm{Ni}$, and $\mathrm{Cu}-\mathrm{Zn}$ correlations were observed only in the male patients. In our study, it was observed that $\mathrm{Zn}$ accumulated in femoral neck of men, simultaneously with $\mathrm{Pb}$. Taking into account that $\mathrm{Zn}$ may reduce the toxic effects of $\mathrm{Pb}$ $[32,39]$, the results may indicate a low risk of toxic influence of $\mathrm{Pb}$ among men.

3.1.2. Smokers. Analysis with the Mann-Whitney $U$-test showed a statistically significant difference between smokers and nonsmokers. The concentrations of $\mathrm{Ca}, \mathrm{Mg}$, and $\mathrm{P}$ in the cancellous bone were significantly lower in smokers than in nonsmokers. Of the trace elements, $\mathrm{Zn}$ concentration was lower in smokers (of borderline significance). $\mathrm{Pb}$ and $\mathrm{Cr}$ were found in higher concentrations in smokers (difference not significant). There were no significant differences in the concentrations of metals in the femoral neck between smokers and nonsmokers (Table 7).

In several previous studies, the differences in the concentrations of some metals in the femur between smokers and nonsmokers were demonstrated $[40,41]$. Only in nonsmokers' femoral necks we did find a significant moderate positive correlation between $\mathrm{Pb}$ and $\mathrm{Zn} \mathrm{Ca}, \mathrm{P}, \mathrm{Mg}$, and $\mathrm{Na}$ and a negative correlation for $\mathrm{Pb} / \mathrm{Mo}$. The femoral neck had a significant high correlation for $\mathrm{Cr} / \mathrm{Ni}$ in smokers that was absent in nonsmokers. The metals $\mathrm{Ca}, \mathrm{P}$, and $\mathrm{Mg}$ moderately negatively correlated with Fe in nonsmokers, while smokers' correlation coefficient was close to zero. In nonsmokers, we observed weak negative correlations for $\mathrm{Mo} / \mathrm{Cu}$ and $\mathrm{Ni} / \mathrm{K}$, and, in smokers, we observed correlations for $\mathrm{Mo} / \mathrm{Cu}$ and $\mathrm{Na} / \mathrm{Pb}$ (Tables 8-9).

Brodziak-Dopierała et al. [28] found correlations between $\mathrm{Cr}-\mathrm{Cu}, \mathrm{Cr}-\mathrm{Zn}, \mathrm{Cu}-\mathrm{Zn}$, and $\mathrm{Cu}-\mathrm{Na}$ in smokers that did not occur in nonsmokers. The correlations between $\mathrm{Cr}-\mathrm{Ni}, \mathrm{Ni}-$ $\mathrm{Cu}$, and $\mathrm{Ni}-\mathrm{Zn}$ were found in both smokers and nonsmokers [28]. Budis et al. [18] found no statistically significant differences in the concentrations of $\mathrm{Fe}$ and $\mathrm{Sr}$ between the group of smokers and nonsmokers. In smokers, a positive correlation between the levels of $\mathrm{Ni}$ and $\mathrm{Cr}$ that was not present in nonsmokers was found. Additionally, in smokers, they observed a significantly increased level of $\mathrm{Pb}$ in bone tissue [22].

The changes in the femoral neck between smoking and nonsmoking people are described by 6 important components, the total variance of which is $79.1 \%$ (Figure 4 ). The first component indicates, as above, the presence of structural elements $\mathrm{Ca}, \mathrm{P}, \mathrm{Na}, \mathrm{Mg}$ and $\mathrm{Zn}$ in the structure of hydroxyapatite. The meaning of $\mathrm{Mo}, \mathrm{Cr}, \mathrm{Cu}$ and $\mathrm{Ni}$ in ion exchange is characterized by the second component, and in nonsmokers also $\mathrm{Pb}$. The $\mathrm{Pb}, \mathrm{Sr}$, and $\mathrm{K}$ in smokers and the $\mathrm{Cu}, \mathrm{Ni}$, and $\mathrm{Fe}$ in nonsmokers are represented by the third component.

The changes in the femoral head between smoking and nonsmoking people are described by 6 important components, the total variance of which is $77.6 \%$ (Figure 5). The first component indicates, as above, the presence of macroelements $\mathrm{Ca}, \mathrm{P}, \mathrm{Na}, \mathrm{Mg}$, and $\mathrm{Zn}$ in the structure of hydroxyapatite. The meaning of $\mathrm{Cr}$ and $\mathrm{Ni}$ in ion exchange is represented by the second component; it also includes $\mathrm{Cu}$, in nonsmokers and $\mathrm{Mo}$ and $\mathrm{Pb}$ in smokers.

3.1.3. Contact with Chemicals. To find the differences in the content of elements in the femur between patients with or without chemical contact, the Mann-Whitney test was used (Table 10). The concentration of $\mathrm{Ni}$ in the femoral head was significantly higher in subjects with exposure to environmental chemicals in comparison to those who had no contact with metals in the environment.

The relations between the examined metals in the bones of the patients were based on Spearman's rank correlation (Tables 11-12). A negative correlation was found between $\mathrm{Ca}$ and $\mathrm{Pb}$ for the femoral neck in patients having contact with chemicals and a positive correlation in patients having no contact with chemicals; only a positive correlation was found for the femoral head in patients having contact with chemicals.

The differences in metal physiology in the femoral head and neck between people with and without chemical contact were described by PCA analysis (Figures 6 and 7). The first component indicates the presence of $\mathrm{Ca}, \mathrm{P}, \mathrm{Na}, \mathrm{Mg}$, and $\mathrm{Zn}$. The meaning of $\mathrm{Cr}, \mathrm{Cu}$, and $\mathrm{Ni}$ content in ion exchange is characterized by the second component, and, in people with chemical contact, also $\mathrm{Pb}, \mathrm{K}$, and $\mathrm{Na}$. The $\mathrm{Pb}$ and $\mathrm{Fe}$ in non-chemical-contact patients and $\mathrm{Mo}, \mathrm{Cr}, \mathrm{Fe}$, and $\mathrm{K}$ in patients with chemical contact are represented by the third component.

3.1.4. Alcohol. Analysis with the Mann-Whitney U-test showed significant differences between alcohol drinkers and abstainers. Patients who consume alcohol had significantly higher mean $\mathrm{Cu}$ content compared to abstainers in both femoral heads and necks.

It should be emphasized that these results have not been previously identified by other researchers. Also the concentrations of $\mathrm{Ni}$ and $\mathrm{Pb}$ were significantly higher in the femoral heads of drinkers compared to abstainers (Table 13). 
TABLE 7: Concentrations of elements (in $\mathrm{mg} / \mathrm{kg}$ on dry mass basis) and differences between them in the cancellous and cortical bone of the femur according to cigarette smoking $(N=96)$.

\begin{tabular}{|c|c|c|c|c|c|c|}
\hline \multirow{5}{*}{ Metal } & \multirow{4}{*}{\multicolumn{3}{|c|}{$\begin{array}{c}\text { Femoral head } \\
\text { AM } \pm \text { SD } \\
\text { Med. } \\
\text { QL-QU }\end{array}$}} & \multirow{4}{*}{\multicolumn{3}{|c|}{$\begin{array}{c}\text { Femoral neck } \\
\text { AM } \pm \text { SD } \\
\text { Med. } \\
\text { QL-QU }\end{array}$}} \\
\hline & & & & & & \\
\hline & & & & & & \\
\hline & & & & & & \\
\hline & Smokers $(n=23)$ & Nonsmokers $(n=73)$ & M-W & Smokers $(n=23)$ & Nonsmokers $(n=73)$ & M-W \\
\hline \multirow{3}{*}{$\mathrm{Ca}$} & $117495 \pm 28846$ & $142758 \pm 36287$ & \multirow{3}{*}{$p<0.01$} & $163117 \pm 38410$ & $155351 \pm 41149$ & \multirow{3}{*}{ NS } \\
\hline & 109008 & 139422 & & 146176 & 153604 & \\
\hline & 97994-139194 & $112362-169574$ & & 134048-203900 & $125302-181456$ & \\
\hline \multirow{3}{*}{$\mathrm{P}$} & $53711 \pm 13014$ & $65562 \pm 16893$ & \multirow{3}{*}{$p<0.01$} & $73176 \pm 16717$ & $69857 \pm 18783$ & \multirow{3}{*}{ NS } \\
\hline & 50535.9 & 64623 & & 68560 & 71192 & \\
\hline & $44247-63841$ & 51705-78096 & & 59106-90919 & $56192-82532$ & \\
\hline \multirow{3}{*}{$\mathrm{Mg}$} & $1300.7 \pm 293.7$ & $1492.8 \pm 367.3$ & \multirow{3}{*}{$p<0.05$} & $1673.5 \pm 294.2$ & $1558.2 \pm 325$ & \multirow{3}{*}{ NS } \\
\hline & 1288.8 & 1455.6 & & 1657.2 & 1552.9 & \\
\hline & $1094.1-1521.9$ & 1219.4-1764.8 & & $1400-1934.1$ & $1342.4-1740.4$ & \\
\hline \multirow{3}{*}{$\mathrm{Na}$} & $5479.5 \pm 897.4$ & $5462.4 \pm 1091.7$ & \multirow{3}{*}{ NS } & $4878.5 \pm 874.6$ & $4619.1 \pm 884.6$ & \multirow{3}{*}{ NS } \\
\hline & 5383.98 & 5451.2 & & 4628.4 & 4663.8 & \\
\hline & 4955.94-5915.15 & 4648.33-6169.32 & & 4196.9-5467.3 & $3935.5-5246.2$ & \\
\hline \multirow{3}{*}{$\mathrm{K}$} & $789.2 \pm 375.5$ & $859.1 \pm 759$ & \multirow{3}{*}{ NS } & $964 \pm 950.6$ & $974.7 \pm 1194.8$ & \multirow{3}{*}{ NS } \\
\hline & 712.9 & 663.4 & & 637.3 & 660 & \\
\hline & $550-1039.6$ & $519.6-960$ & & 534.7-1138.6 & $500-980$ & \\
\hline \multirow{3}{*}{$\mathrm{Zn}$} & $66.01 \pm 12.24$ & $74.01 \pm 16.63$ & \multirow{3}{*}{$p<0.05$} & $73.67 \pm 15.54$ & $67.14 \pm 12.33$ & \multirow{3}{*}{ NS } \\
\hline & 65.91 & 72.1 & & 66.77 & 65.87 & \\
\hline & $55.04-75.8$ & $62.64-89.45$ & & $62.63-83.77$ & $57.56-75.2$ & \\
\hline \multirow{3}{*}{$\mathrm{Cu}$} & $0.94 \pm 0.78$ & $0.9 \pm 0.91$ & & $0.88 \pm 1.46$ & $0.89 \pm 1.05$ & \\
\hline & 0.89 & 0.72 & NS & 0.04 & 0.79 & NS \\
\hline & $0.04-1.45$ & $0.04-1.5$ & & $0.04-1.44$ & $0.04-1.18$ & \\
\hline & $2 \pm 3.57$ & $1.12 \pm 1.6$ & & $1.65 \pm 1.92$ & $1.38 \pm 1.68$ & \\
\hline $\mathrm{Cr}$ & 0.43 & 0.5 & NS & 0.95 & 0.76 & NS \\
\hline & $0.12-1.95$ & $0.12-1.41$ & & $0.45-2.28$ & $0.12-1.58$ & \\
\hline & $0.72 \pm 1.47$ & $0.56 \pm 1.19$ & & $1.28 \pm 3.11$ & $0.63 \pm 1.95$ & \\
\hline $\mathrm{Ni}$ & 0.03 & 0.03 & NS & 0.03 & 0.03 & NS \\
\hline & $0.03-1.05$ & $0.03-0.69$ & & $0.03-1.15$ & $0.03-0.49$ & \\
\hline & $111.55 \pm 79.08$ & $128.47 \pm 113.56$ & & $94.12 \pm 44.24$ & $143.3 \pm 156.24$ & \\
\hline $\mathrm{Fe}$ & 90.8 & 96.44 & NS & 88.64 & 93.52 & NS \\
\hline & $47.26-171.83$ & 54.54-142.18 & & $56.73-136.87$ & $55.28-167.62$ & \\
\hline & $38.43 \pm 14.88$ & $45.73 \pm 29.03$ & & $49.82 \pm 16.72$ & $46.46 \pm 24.32$ & \\
\hline $\mathrm{Sr}$ & 36.39 & 36.74 & NS & 45.73 & 41.89 & NS \\
\hline & $25.22-44.43$ & $26.16-52.99$ & & $39.73-57.13$ & $29.86-52.54$ & \\
\hline & $0.54 \pm 0.6$ & $0.57 \pm 0.6$ & & $0.66 \pm 0.58$ & $0.75 \pm 0.71$ & \\
\hline Mo & 0.18 & 0.18 & NS & 0.18 & 0.18 & NS \\
\hline & $0.18-1.02$ & $0.18-1.15$ & & $0.18-1.21$ & $0.18-1.43$ & \\
\hline & $2.5 \pm 2.1$ & $2.5 \pm 1.5$ & & $2.71 \pm 1.54$ & $2.32 \pm 1.21$ & \\
\hline $\mathrm{Ba}$ & 2.04 & 2.09 & NS & 2.63 & 2.07 & NS \\
\hline & $1.52-2.97$ & $1.46-3.08$ & & $1.41-3.48$ & $1.35-3.11$ & \\
\hline & $1.38 \pm 1.67$ & $1.08 \pm 1.46$ & & $1.04 \pm 1.33$ & $1.09 \pm 1.4$ & \\
\hline $\mathrm{Pb}$ & 0.32 & 0.32 & NS & 0.32 & 0.32 & NS \\
\hline & $0.32-2.18$ & $0.32-1.44$ & & $0.32-1.35$ & $0.32-1.57$ & \\
\hline
\end{tabular}

AM: arithmetic mean; SD: standard deviation; Med.: median: M-W, QL: lower quartile; QU: upper quartile; M-W: Mann-Whitney U-test; $p$ : level of significance; NS: nonsignificant difference. 


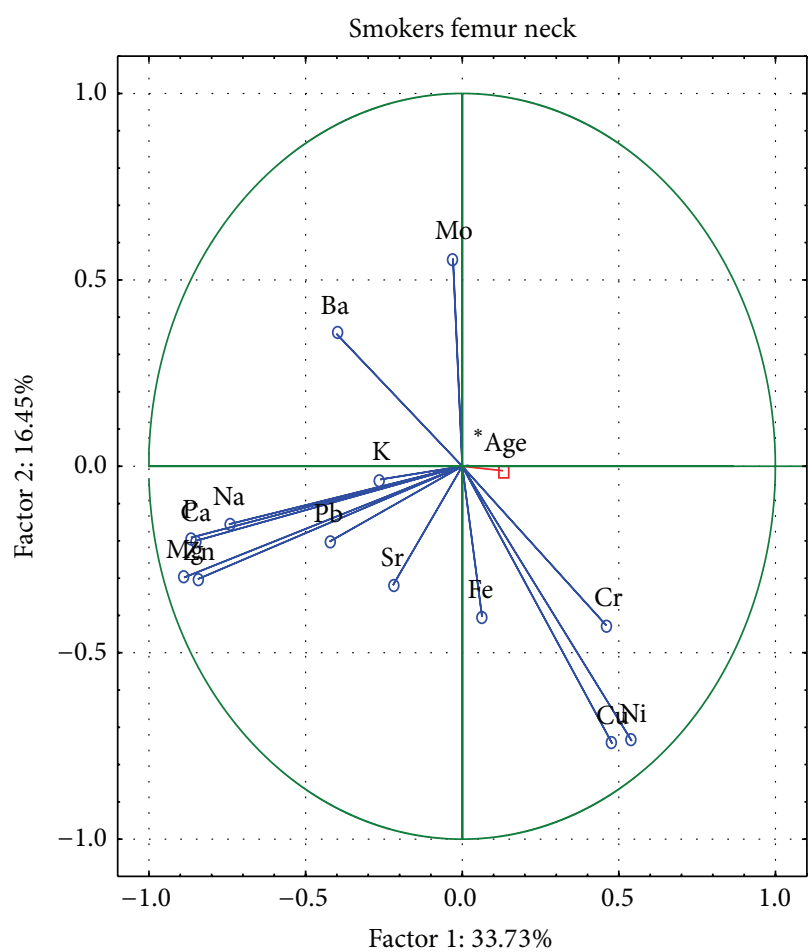

O Active

$\square$ Add.

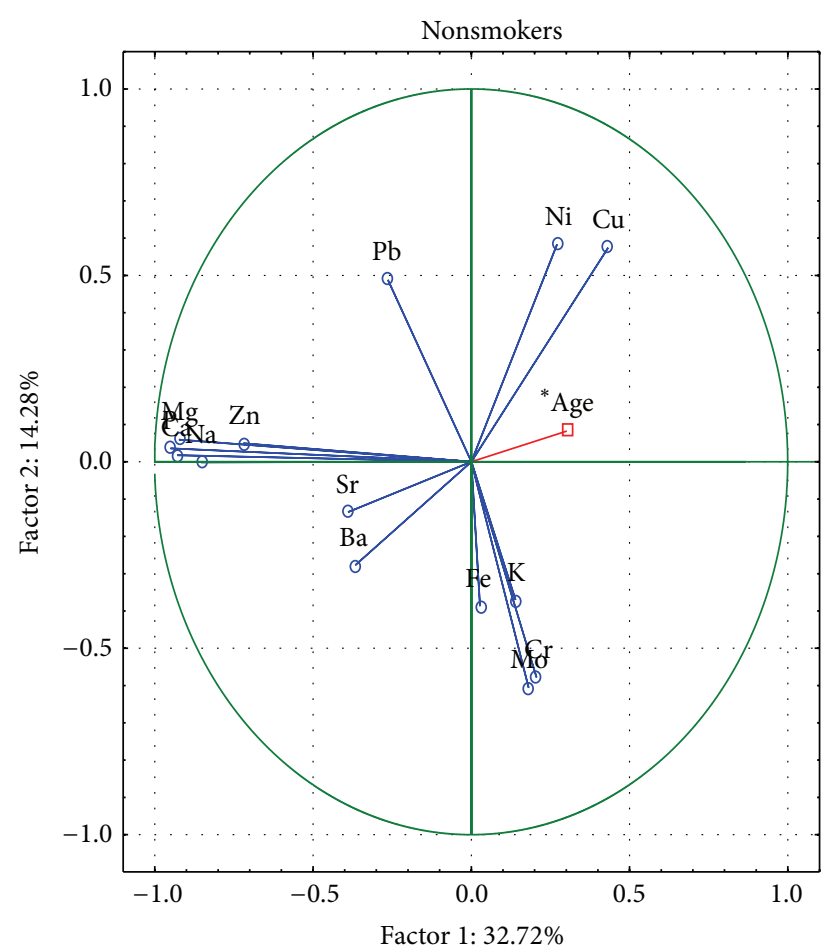

O Active

$\square$ Add.

Figure 4: A graphic illustration of Principal Components Analysis of contents of elements according to cigarette smoking for femoral neck. Projection of the variables on the factor plane of the first two principal components for smokers and nonsmokers.

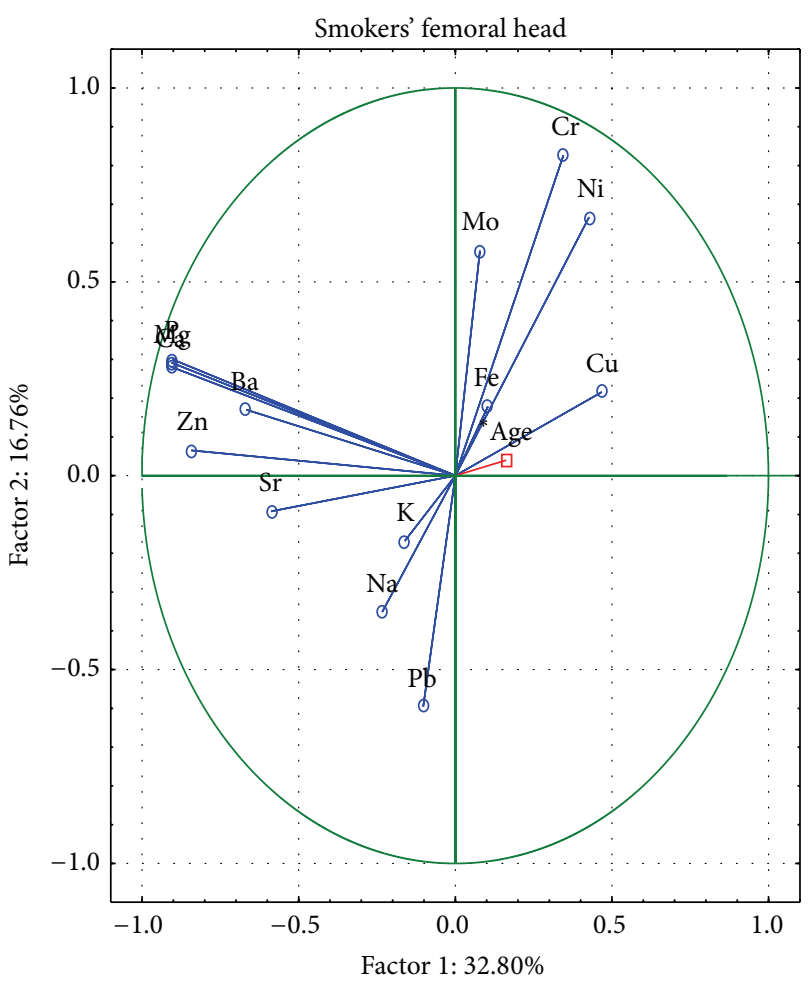

O Active

$\square$ Add.

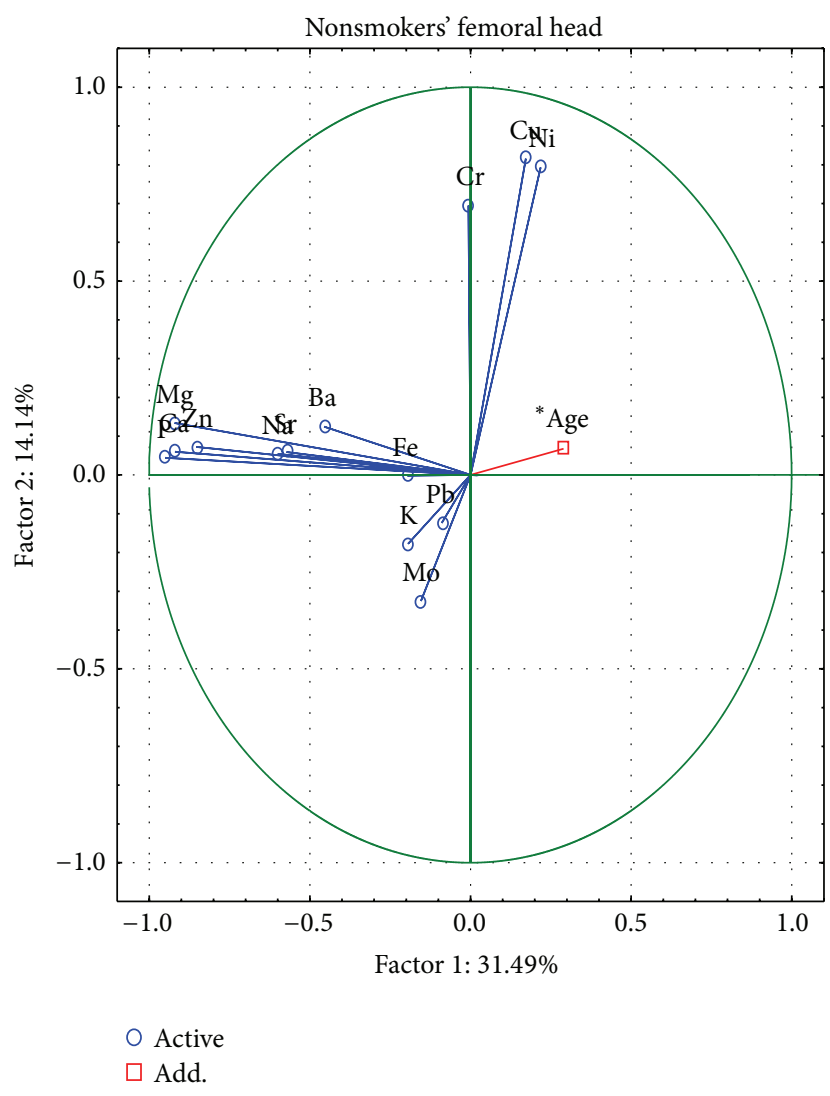

Octive

Figure 5: A graphic illustration of Principal Components Analysis of contents of elements according to cigarette smoking for femoral head. Projection of the variables on the factor plane of the first two principal components for smokers and nonsmokers. 

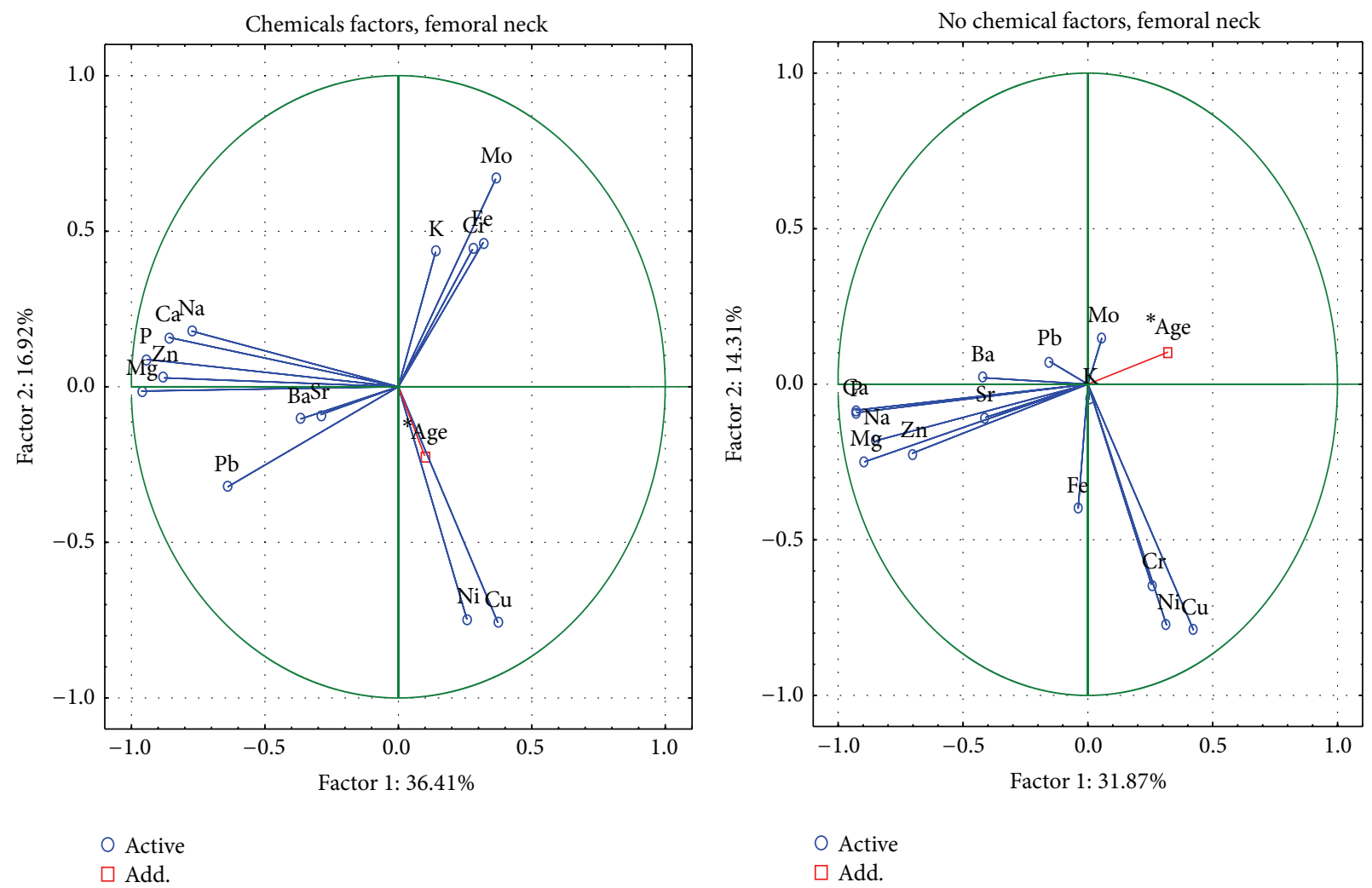

Figure 6: A graphic illustration of Principal Components Analysis of contents of elements according to chemical factors for femoral neck. Projection of the variables on the factor plane of the first two principal components for chemical and no chemical factors.

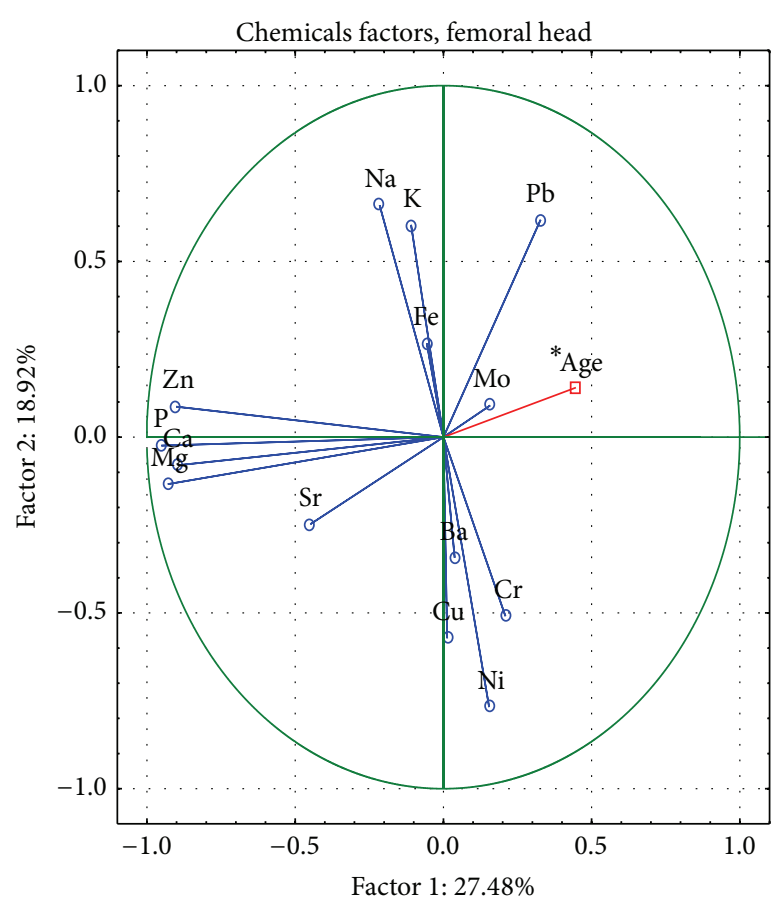

O Active

$\square$ Add.

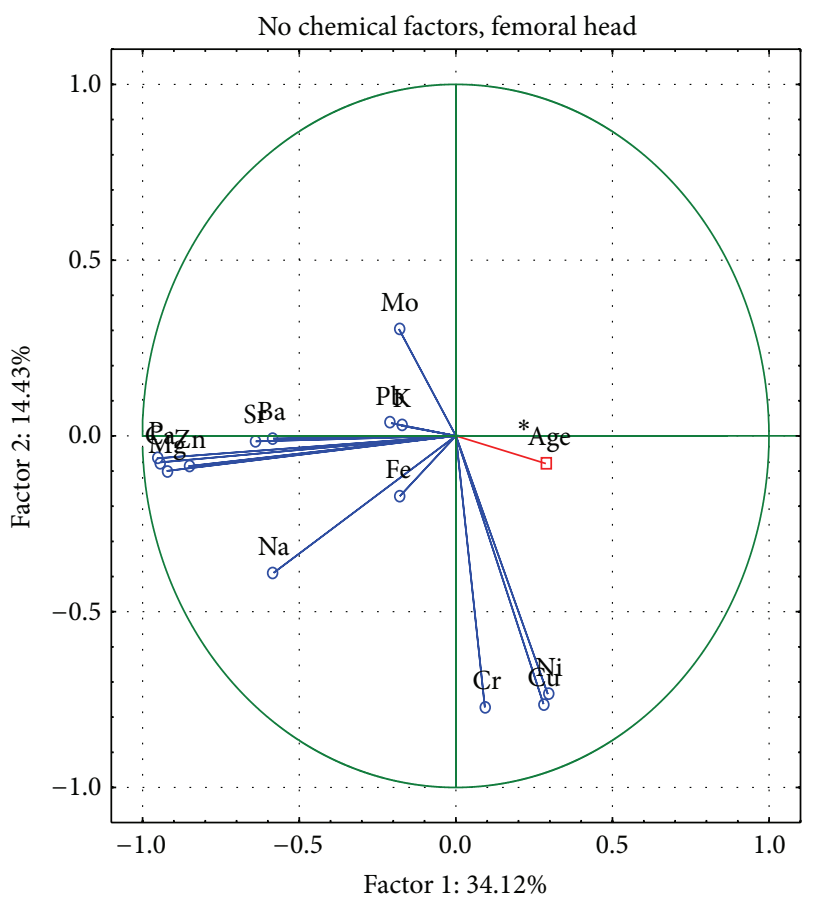

O Active

$\square$ Add.

Figure 7: A graphic illustration of Principal Components Analysis of contents of elements according chemical to factors for femoral head. Projection of the variables on the factor plane of the first two principal components for chemical and no chemical factors. 
TABLE 8: Spearman correlation coefficients for metals found in femoral neck of smokers and nonsmokers.

\begin{tabular}{|c|c|c|c|c|c|c|c|c|c|c|c|c|c|c|c|}
\hline Neck & $\begin{array}{c}\text { Mo } \\
\text { Nonsmoker }\end{array}$ & $\mathrm{Cr}$ & $\mathrm{Zn}$ & $\mathrm{Pb}$ & $\mathrm{Cu}$ & $\mathrm{Ni}$ & $\mathrm{Fe}$ & $\mathrm{Mg}$ & $\mathrm{K}$ & $\mathrm{P}$ & $\mathrm{Sr}$ & $\mathrm{Ba}$ & $\mathrm{Na}$ & $\mathrm{Ca}$ & Age \\
\hline Mo & $\mathrm{x}$ & 0.20 & -0.14 & $-0.31^{*}$ & -0.13 & 0.01 & 0.06 & -0.17 & 0.00 & -0.13 & -0.03 & 0.01 & -0.11 & -0.10 & -0.08 \\
\hline $\mathrm{Cr}$ & -0.22 & $\mathrm{x}$ & -0.05 & -0.17 & $0.23^{*}$ & 0.17 & $.39^{*}$ & -0.09 & $0.27^{*}$ & -0.22 & -0.10 & -0.01 & -0.08 & -0.16 & 0.10 \\
\hline $\mathrm{Zn}$ & -0.08 & -0.25 & $\mathrm{x}$ & $0.29^{*}$ & -0.05 & -0.13 & -0.21 & $0.70^{*}$ & 0.00 & $0.61^{*}$ & $0.34^{*}$ & 0.19 & $0.63^{*}$ & $0.60^{*}$ & -0.22 \\
\hline $\mathrm{Pb}$ & -0.32 & -0.22 & 0.15 & $\mathrm{x}$ & 0.09 & -0.01 & -0.12 & $0.33^{*}$ & -0.13 & $0.28^{*}$ & 0.05 & -0.10 & $0.29^{*}$ & $0.27^{*}$ & 0.08 \\
\hline $\mathrm{Cu}$ & -0.37 & $0.43^{*}$ & -0.21 & 0.23 & $\mathrm{x}$ & $0.51^{*}$ & $0.32^{*}$ & $-0.26^{*}$ & -0.05 & $-0.40^{*}$ & $-0.25^{*}$ & -0.19 & $-0.26^{*}$ & $-0.39^{*}$ & 0.12 \\
\hline $\mathrm{Ni}$ & -0.19 & $0.74^{*}$ & -0.28 & 0.05 & $0.69^{*}$ & $\mathrm{x}$ & 0.15 & $-0.25^{*}$ & -0.03 & $-0.39^{*}$ & -0.03 & -0.11 & $-0.25^{*}$ & $-0.32^{*}$ & 0.05 \\
\hline $\mathrm{Fe}$ & -0.39 & 0.35 & -0.03 & -0.19 & 0.40 & 0.17 & $\mathrm{x}$ & $-0.24^{*}$ & $0.26^{*}$ & $-0.27^{*}$ & -0.20 & -0.07 & -0.06 & $-0.24^{*}$ & 0.02 \\
\hline $\mathrm{Mg}$ & -0.08 & -0.21 & $0.89^{*}$ & 0.11 & -0.14 & -0.39 & 0.08 & $\mathrm{x}$ & -0.16 & $0.90^{*}$ & $0.45^{*}$ & $0.37^{*}$ & $0.82^{*}$ & $0.86^{*}$ & $-0.30^{*}$ \\
\hline K & -0.08 & 0.18 & -0.08 & -0.01 & 0.12 & -0.11 & 0.31 & 0.02 & $\mathrm{x}$ & $-0.23^{*}$ & & -0.20 & 0.02 & -0.22 & 0.09 \\
\hline $\mathrm{P}$ & 0.02 & -0.21 & $0.71^{*}$ & -0.02 & -0.30 & -0.38 & 0.07 & $0.86^{*}$ & -0.13 & $\mathrm{x}$ & $0.42^{*}$ & $0.36^{*}$ & $0.82^{*}$ & $0.95^{*}$ & $-0.34^{*}$ \\
\hline $\mathrm{Sr}$ & -0.14 & -0.03 & 0.35 & $0.48^{*}$ & 0.17 & 0.18 & -0.18 & 0.31 & -0.13 & 0.27 & $\mathrm{x}$ & $0.35^{*}$ & $0.41^{*}$ & $0.39^{*}$ & $-0.31^{*}$ \\
\hline $\mathrm{Ba}$ & 0.19 & -0.39 & 0.28 & 0.34 & -0.19 & -0.38 & -0.31 & 0.35 & -0.09 & 0.31 & 0.11 & $\mathrm{x}$ & $0.25^{*}$ & $0.33^{*}$ & -0.20 \\
\hline $\mathrm{Na}$ & 0.14 & -0.26 & $0.65^{*}$ & 0.08 & -0.21 & -0.34 & 0.11 & $0.69^{*}$ & 0.31 & $0.66^{*}$ & 0.35 & 0.12 & $\mathrm{x}$ & $0.78^{*}$ & $-0.28^{*}$ \\
\hline $\mathrm{Ca}$ & 0.00 & -0.19 & $0.69^{*}$ & 0.00 & -0.30 & -0.35 & 0.08 & $0.84^{*}$ & -0.05 & $0.97^{*}$ & 0.26 & 0.28 & $0.63^{*}$ & $\mathrm{x}$ & $-0.34^{*}$ \\
\hline Age & $\begin{array}{c}0.26 \\
\text { Smoker }\end{array}$ & 0.09 & -0.07 & -0.06 & 0.33 & 0.08 & 0.38 & -0.06 & 0.23 & -0.18 & -0.06 & -0.18 & 0.11 & -0.17 & $\mathrm{x}$ \\
\hline
\end{tabular}

${ }^{*}$ Statistically significant.

TABLE 9: Spearman correlation coefficients for metals found in femoral head of smokers and nonsmokers.

\begin{tabular}{lcccccccccccccccccc}
\hline Head & $\begin{array}{c}\mathrm{Mo} \\
\text { Nonsmoker }\end{array}$ & $\mathrm{Cr}$ & $\mathrm{Zn}$ & $\mathrm{Pb}$ & $\mathrm{Cu}$ & $\mathrm{Ni}$ & $\mathrm{Fe}$ & $\mathrm{Mg}$ & $\mathrm{K}$ & $\mathrm{P}$ & $\mathrm{Sr}$ & $\mathrm{Ba}$ & $\mathrm{Na}$ & $\mathrm{Ca}$ & $\mathrm{Age}$ \\
& & & & & & & & & & & & & & \\
$\mathrm{Mo}$ & $\mathrm{x}$ & -0.11 & 0.12 & 0.13 & $-0.23^{*}$ & -0.16 & 0.08 & 0.04 & 0.19 & 0.11 & 0.08 & -0.03 & -0.04 & 0.05 & 0.03 \\
$\mathrm{Cr}$ & -0.01 & $\mathrm{x}$ & 0.04 & -0.08 & $0.43^{*}$ & 0.15 & $0.28^{*}$ & 0.10 & 0.13 & 0.06 & -0.04 & 0.10 & 0.17 & 0.05 & 0.05 \\
$\mathrm{Zn}$ & 0.04 & -0.32 & $\mathrm{x}$ & 0.04 & -0.04 & -0.16 & 0.17 & $0.79^{*}$ & 0.20 & $0.81^{*}$ & $0.52^{*}$ & $0.38^{*}$ & $0.50^{*}$ & $0.77^{*}$ & -0.15 \\
$\mathrm{~Pb}$ & -0.29 & -0.37 & 0.33 & $\mathrm{x}$ & 0.01 & 0.07 & 0.06 & 0.12 & 0.01 & 0.09 & -0.09 & 0.00 & 0.13 & 0.13 & 0.20 \\
$\mathrm{Cu}$ & -0.17 & $0.47^{*}$ & -0.35 & -0.15 & $\mathrm{x}$ & $0.40^{*}$ & 0.15 & 0.00 & 0.15 & -0.11 & -0.08 & -0.09 & 0.00 & -0.12 & 0.05 \\
$\mathrm{Ni}$ & 0.07 & 0.20 & -0.07 & -0.26 & $0.53^{*}$ & $\mathrm{x}$ & -0.22 & -0.14 & $-0.37^{*}$ & -0.18 & -0.13 & 0.04 & $-0.32^{*}$ & -0.19 & -0.01 \\
$\mathrm{Fe}$ & -0.04 & $0.55^{*}$ & -0.03 & -0.10 & 0.16 & -0.05 & $\mathrm{x}$ & 0.05 & $0.33^{*}$ & 0.11 & 0.01 & -0.08 & 0.22 & 0.05 & 0.14 \\
$\mathrm{Mg}$ & 0.16 & -0.04 & $0.75^{*}$ & 0.00 & -0.27 & -0.21 & 0.08 & $\mathrm{x}$ & $0.25^{*}$ & $0.91^{*}$ & $0.61^{*}$ & $0.49^{*}$ & $0.49^{*}$ & $0.88^{*}$ & -0.21 \\
$\mathrm{~K}$ & -0.30 & 0.30 & -0.19 & 0.04 & 0.39 & -0.05 & 0.18 & 0.05 & $\mathrm{x}$ & 0.19 & $0.29^{*}$ & 0.01 & $0.54^{*}$ & 0.13 & 0.07 \\
$\mathrm{P}$ & -0.07 & 0.00 & $0.73^{*}$ & -0.10 & -0.36 & -0.19 & 0.07 & $0.85^{*}$ & -0.08 & $\mathrm{x}$ & $0.6^{*}$ & $0.48^{*}$ & $0.52^{*}$ & $0.95^{*}$ & $-0.27^{*}$ \\
$\mathrm{Sr}$ & -0.09 & -0.35 & $0.47^{*}$ & 0.10 & -0.14 & 0.16 & -0.28 & 0.36 & 0.13 & 0.36 & $\mathrm{x}$ & $0.38^{*}$ & $0.38^{*}$ & $0.59^{*}$ & -0.12 \\
$\mathrm{Ba}$ & 0.03 & 0.03 & $0.57^{*}$ & 0.23 & -0.27 & 0.05 & 0.07 & $0.49^{*}$ & -0.26 & $0.56^{*}$ & $0.48^{*}$ & $\mathrm{x}$ & 0.23 & $0.44^{*}$ & -0.08 \\
$\mathrm{Na}$ & $-0.48^{*}$ & -0.02 & 0.28 & $0.45^{*}$ & 0.13 & 0.15 & -0.23 & -0.02 & 0.13 & 0.07 & 0.11 & 0.14 & $\mathrm{x}$ & $0.46^{*}$ & -0.12 \\
$\mathrm{Ca}$ & -0.10 & -0.08 & $0.75^{*}$ & -0.02 & -0.29 & -0.16 & 0.02 & $0.83^{*}$ & -0.07 & $0.97^{*}$ & 0.38 & $0.54^{*}$ & 0.07 & $\mathrm{x}$ & $-0.23^{*}$ \\
$\mathrm{Age}$ & 0.13 & -0.07 & -0.25 & -0.16 & 0.10 & 0.21 & -0.13 & -0.11 & 0.03 & -0.19 & -0.09 & -0.08 & -0.13 & -0.16 & $\mathrm{x}$ \\
& $\mathrm{Smoker}$ & & & & & & & & & & & & & \\
\hline
\end{tabular}

${ }^{*}$ Statistically significant.

Exposure to $\mathrm{Pb}$ or/and ethanol decreased bone formation and increased its resorption, resulting in the bone demineralization. These effects were accompanied by destroying the hormonal regulation of mineral metabolism and $\mathrm{Ca}$ and $\mathrm{P}$ imbalance [42]. The mechanism underlying ethanolassociated osteopenia seems to be a direct effect of alcohol on bone cells and an indirect or modulating effect through mineral regulating hormones such as vitamin $\mathrm{D}$ metabolites, parathyroid hormone, and calcitonin. The modulating effects of these hormones on bone and mineral metabolism are observed in acute and chronic alcohol consumption [43].
The correlations for metals in femoral necks and heads are described by the Spearman's rank correlation (Tables 14 and 15). In the femoral neck, we observed a statistically significant negative correlation between $\mathrm{Fe}$ and age and the concentration of metals $\mathrm{Ca}, \mathrm{P}$, and $\mathrm{Mg}$ in abstainers. The deposition of $\mathrm{Pb}$ with age was demonstrated in abstainers, but no correlation was observed in drinkers. In the femoral head, we observed a positive correlation between $\mathrm{Mo} / \mathrm{Fe}$ in people who consume alcohol and negative one between $\mathrm{Mo} / \mathrm{Cu}$ in abstainers. The drinkers had a significantly negative correlation for $\mathrm{Ni} / \mathrm{Zn}$ and positive one for $\mathrm{Ni} / \mathrm{Cu}$. In both groups, $\mathrm{Cr}$ 
TABLE 10: Concentrations of elements (in $\mathrm{mg} / \mathrm{kg}$ on dry mass basis) and differences between them in the cancellous and cortical bone of the femur according to contact with chemicals $(N=96)$.

\begin{tabular}{|c|c|c|c|c|c|c|}
\hline \multirow{5}{*}{ Contact } & \multirow{4}{*}{\multicolumn{3}{|c|}{$\begin{array}{c}\text { Femoral head } \\
\mathrm{AM} \pm \mathrm{SD} \\
\text { Med. } \\
\text { QL-QU }\end{array}$}} & \multirow{4}{*}{\multicolumn{3}{|c|}{$\begin{array}{c}\text { Femoral neck } \\
\mathrm{AM} \pm \mathrm{SD} \\
\text { Med. } \\
\text { QL-QU }\end{array}$}} \\
\hline & & & & & & \\
\hline & & & & & & \\
\hline & & & & & & \\
\hline & Yes $n=29$ & No $n=67$ & M-W & Yes $n=29$ & No $n=67$ & M-W \\
\hline \multirow{3}{*}{$\mathrm{Ca}$} & $129760 \pm 30767$ & $139711 \pm 38092$ & \multirow{3}{*}{ NS } & $155742 \pm 38132$ & $157848 \pm 41674$ & \multirow{3}{*}{ NS } \\
\hline & 121696 & 133780 & & 153604 & 150986 & \\
\hline & $106560-143042$ & $106146-173244$ & & $131382-181456$ & $125924-184734$ & \\
\hline \multirow{3}{*}{$\mathrm{Mg}$} & $1385.5 \pm 294.8$ & $1473.3 \pm 382.7$ & \multirow{3}{*}{ NS } & $1559.1 \pm 338.4$ & $1597.4 \pm 314$ & \multirow{3}{*}{ NS } \\
\hline & 1334.5 & 1384.04 & & 1522 & 1612.97 & \\
\hline & $1183.17-1610.5$ & $1159.13-1784.71$ & & $1387.55-1732.5$ & $1372.67-1793.73$ & \\
\hline \multirow{3}{*}{$\mathrm{P}$} & $60891.1 \pm 15375.9$ & $63515.9 \pm 17395.5$ & \multirow{3}{*}{ NS } & $68897.5 \pm 17470.4$ & $71411.8 \pm 18695.6$ & \multirow{3}{*}{ NS } \\
\hline & 59071.29 & 59118 & & 70672.38 & 68560 & \\
\hline & $48262-69132.67$ & 47872.9-78380.2 & & $55192.08-81000$ & $57827.45-84699.01$ & \\
\hline \multirow{3}{*}{$\mathrm{Na}$} & $5427.4 \pm 1079.4$ & $5483.5 \pm 1036.1$ & \multirow{3}{*}{ NS } & $4559.5 \pm 998.3$ & $4733.9 \pm 833.2$ & \multirow{3}{*}{ NS } \\
\hline & 5334.02 & 5456.31 & & 4458 & 4812.28 & \\
\hline & 4975.84-6217.92 & $4648.33-6093.08$ & & $3935.54-5181.37$ & 4072.3-5358.02 & \\
\hline \multirow{3}{*}{ K } & $687.4 \pm 251.4$ & $909.4 \pm 796.7$ & \multirow{3}{*}{ NS } & $1094.3 \pm 1822.1$ & $919.2 \pm 663.7$ & \multirow{3}{*}{ NS } \\
\hline & 611.65 & 712.87 & & 570 & 770 & \\
\hline & $500-810$ & $564.36-1039.6$ & & $450-950$ & $534.65-1138.61$ & \\
\hline \multirow{3}{*}{$\mathrm{Zn}$} & $72.8 \pm 13.5$ & $71.8 \pm 17.1$ & \multirow{3}{*}{ NS } & $69.4 \pm 14.6$ & $68.4 \pm 12.9$ & \multirow{3}{*}{ NS } \\
\hline & 71.01 & 69.75 & & 69.42 & 65.4 & \\
\hline & $62.61-81.98$ & $57.65-87.98$ & & $57.56-76.51$ & $58.76-75.45$ & \\
\hline \multirow{3}{*}{$\mathrm{Cu}$} & $1 \pm 1$ & $0.9 \pm 0.8$ & & $1 \pm 1.5$ & $0.8 \pm 1$ & \\
\hline & 0.9 & 0.76 & NS & 0.58 & 0.77 & NS \\
\hline & $0.04-1.66$ & $0.04-1.37$ & & $0.04-1.22$ & $0.04-1.12$ & \\
\hline & $1.6 \pm 3.1$ & $1.2 \pm 1.8$ & & $1.6 \pm 1.8$ & $1.4 \pm 1.7$ & \\
\hline $\mathrm{Cr}$ & 0.5 & 0.48 & NS & 0.95 & 0.7 & NS \\
\hline & $0.12-1.68$ & $0.12-1.67$ & & $0.51-1.91$ & $0.12-1.7$ & \\
\hline & $1.1 \pm 1.9$ & $0.4 \pm 0.8$ & & $1.2 \pm 3$ & $0.6 \pm 1.9$ & \\
\hline $\mathrm{Ni}$ & 0.21 & 0.03 & $p<0.05$ & 0.03 & 0.03 & NS \\
\hline & $0.03-1.08$ & $0.03-0.5$ & & $0.03-0.54$ & $0.03-0.49$ & \\
\hline & $119.2 \pm 104.9$ & $126.7 \pm 107.4$ & & $132.7 \pm 119.1$ & $131 \pm 148$ & \\
\hline $\mathrm{Fe}$ & 96.44 & 90.8 & NS & 91.7 & 90.24 & NS \\
\hline & $47.26-144.48$ & $55.58-142.18$ & & 71.23-141.99 & $50.35-155.29$ & \\
\hline & $39.3 \pm 26.7$ & $46 \pm 26.3$ & & $44.4 \pm 23.5$ & $48.5 \pm 22.4$ & \\
\hline $\mathrm{Sr}$ & 34.17 & 37.97 & NS & 42.55 & 44.54 & NS \\
\hline & $25.81-41.54$ & $26.96-54.91$ & & $29.8-47.52$ & $33.27-56.27$ & \\
\hline & $0.5 \pm 0.6$ & $0.6 \pm 0.6$ & & $0.8 \pm 0.7$ & $0.7 \pm 0.7$ & \\
\hline Mo & 0.18 & 0.18 & NS & 0.86 & 0.18 & NS \\
\hline & $0.18-0.18$ & $0.18-1.15$ & & $0.18-1.44$ & $0.18-1.33$ & \\
\hline & $2.3 \pm 1.3$ & $2.5 \pm 1.8$ & & $2.5 \pm 1.3$ & $2.4 \pm 1.3$ & \\
\hline $\mathrm{Ba}$ & 1.9 & 2.1 & NS & 2.25 & 2.24 & NS \\
\hline & $1.57-2.94$ & $1.45-3.09$ & & $1.46-3.49$ & $1.38-3.11$ & \\
\hline & $1.4 \pm 1.8$ & $1 \pm 1.4$ & & $1 \pm 1.3$ & $1.1 \pm 1.4$ & \\
\hline $\mathrm{Pb}$ & 0.32 & 0.32 & NS & 0.32 & 0.32 & NS \\
\hline & $0.32-2.18$ & $0.32-1.53$ & & $0.32-1.28$ & $0.32-1.81$ & \\
\hline
\end{tabular}

AM: arithmetic mean; SD: standard deviation; Med.: median; QL: lower quartile; QU: upper quartile; M-W, Mann-Whitney U-test; $p$ : level of significance; NS: nonsignificant difference. 
TABLE 11: Spearman correlation coefficients for metals found in femoral neck of patients with chemicals contact and without contact.

\begin{tabular}{lcccccccccccccccc}
\hline neck & $\mathrm{Mo}$ & $\mathrm{Cr}$ & $\mathrm{Zn}$ & $\mathrm{Pb}$ & $\mathrm{Cu}$ & $\mathrm{Ni}$ & $\mathrm{Fe}$ & $\mathrm{Mg}$ & $\mathrm{K}$ & $\mathrm{P}$ & $\mathrm{Sr}$ & $\mathrm{Ba}$ & $\mathrm{Na}$ & $\mathrm{Ca}$ & $\mathrm{Age}$ \\
Contact with chemicals & $\mathrm{No}$ & & & & & & & & & & & & \\
\hline $\mathrm{Mo}$ & $\mathrm{x}$ & -0.17 & 0.16 & -0.01 & $-0.27^{*}$ & -0.09 & -0.04 & 0.10 & 0.00 & 0.13 & 0.10 & -0.03 & -0.20 & 0.12 & 0.00 \\
$\mathrm{Cr}$ & 0.14 & $\mathrm{x}$ & -0.08 & -0.05 & $0.42^{*}$ & 0.15 & $0.32^{*}$ & 0.01 & 0.22 & 0.02 & -0.07 & 0.02 & 0.20 & 0.00 & 0.13 \\
$\mathrm{Zn}$ & -0.07 & 0.11 & $\mathrm{x}$ & 0.19 & -0.11 & -0.16 & 0.13 & $0.81^{*}$ & 0.12 & $0.81^{*}$ & $0.54^{*}$ & $0.49^{*}$ & $0.52^{*}$ & $0.81^{*}$ & -0.09 \\
$\mathrm{~Pb}$ & 0.08 & $-0.38^{*}$ & -0.20 & $\mathrm{x}$ & 0.05 & 0.12 & -0.07 & $0.27^{*}$ & -0.07 & 0.22 & -0.01 & 0.19 & 0.14 & $0.25^{*}$ & 0.03 \\
$\mathrm{Cu}$ & -0.13 & $0.47^{*}$ & -0.06 & -0.16 & $\mathrm{x}$ & $0.36^{*}$ & 0.21 & -0.12 & $0.32^{*}$ & -0.21 & -0.17 & -0.20 & 0.17 & -0.21 & 0.09 \\
$\mathrm{Ni}$ & -0.09 & 0.21 & -0.16 & -0.25 & $0.59^{*}$ & $\mathrm{x}$ & -0.13 & -0.16 & -0.23 & -0.17 & -0.12 & -0.03 & -0.06 & -0.15 & 0.07 \\
$\mathrm{Fe}$ & 0.25 & 0.36 & 0.16 & 0.22 & 0.04 & -0.28 & $\mathrm{x}$ & 0.02 & $0.30^{*}$ & 0.06 & 0.11 & -0.05 & 0.08 & 0.05 & 0.21 \\
$\mathrm{Mg}$ & -0.08 & 0.21 & $0.81^{*}$ & $-0.43^{*}$ & 0.11 & -0.04 & 0.04 & $\mathrm{x}$ & 0.21 & $0.92^{*}$ & $0.59^{*}$ & $0.57^{*}$ & $0.50^{*}$ & $0.91^{*}$ & -0.20 \\
$\mathrm{~K}$ & 0.25 & 0.06 & 0.08 & 0.29 & -0.03 & -0.34 & 0.28 & 0.01 & $\mathrm{x}$ & 0.10 & $0.29^{*}$ & -0.01 & $0.41^{*}$ & 0.07 & -0.06 \\
$\mathrm{P}$ & -0.09 & 0.17 & $0.78^{*}$ & $-0.43^{*}$ & 0.09 & -0.05 & 0.16 & $0.87^{*}$ & 0.09 & $\mathrm{x}$ & $0.62^{*}$ & $0.61^{*}$ & $0.51^{*}$ & $0.99^{*}$ & -0.23 \\
$\mathrm{Sr}$ & -0.04 & -0.21 & $0.47^{*}$ & -0.11 & 0.11 & 0.16 & $-0.40^{*}$ & $0.51^{*}$ & 0.09 & 0.29 & $\mathrm{x}$ & $0.49^{*}$ & $0.44^{*}$ & $0.61^{*}$ & -0.21 \\
$\mathrm{Ba}$ & 0.03 & 0.18 & 0.19 & -0.27 & 0.05 & 0.20 & 0.06 & 0.30 & -0.21 & 0.09 & 0.16 & $\mathrm{x}$ & $0.35^{*}$ & $0.61^{*}$ & -0.03 \\
$\mathrm{Na}$ & 0.02 & 0.00 & 0.33 & 0.37 & -0.20 & $-0.42^{*}$ & 0.23 & 0.10 & $0.54^{*}$ & 0.14 & 0.20 & -0.16 & $\mathrm{x}$ & $0.49^{*}$ & -0.21 \\
$\mathrm{Ca}$ & -0.25 & 0.08 & $0.72^{*}$ & $-0.39^{*}$ & 0.06 & -0.04 & -0.04 & $0.76^{*}$ & -0.05 & $0.90^{*}$ & 0.32 & -0.07 & 0.00 & $\mathrm{x}$ & -0.23 \\
$\mathrm{Age}$ & 0.15 & 0.03 & -0.36 & 0.24 & 0.07 & 0.08 & -0.05 & -0.36 & 0.34 & -0.21 & -0.30 & -0.22 & 0.00 & -0.22 & $\mathrm{x}$ \\
& $\mathrm{Yes}$ & & & & & & & & & & & & & \\
\hline
\end{tabular}

* Statistically significant.

TABLE 12: Spearman correlation coefficients for metals found in femoral head of patients with chemicals contact and without contact.

\begin{tabular}{|c|c|c|c|c|c|c|c|c|c|c|c|c|c|c|c|}
\hline Head & Mo & $\mathrm{Cr}$ & $\mathrm{Zn}$ & $\mathrm{Pb}$ & $\mathrm{Cu}$ & $\mathrm{Ni}$ & $\mathrm{Fe}$ & $\mathrm{Mg}$ & K & $\mathrm{P}$ & $\mathrm{Sr}$ & $\mathrm{Ba}$ & $\mathrm{Na}$ & $\mathrm{Ca}$ & Age \\
\hline Contact with chemicals & No & & & & & & & & & & & & & & \\
\hline Mo & $\mathrm{x}$ & 0.04 & -0.07 & $-0.25^{*}$ & -0.17 & -0.06 & -0.15 & -0.08 & -0.06 & -0.06 & 0.04 & 0.16 & -0.09 & -0.08 & 0.00 \\
\hline $\mathrm{Cr}$ & 0.29 & $\mathrm{x}$ & -0.06 & -0.18 & $0.34^{*}$ & $0.36^{*}$ & $0.43^{*}$ & 0.00 & $0.30^{*}$ & -0.14 & 0.01 & 0.00 & 0.02 & -0.15 & 0.03 \\
\hline $\mathrm{Zn}$ & -0.30 & -0.13 & $\mathrm{x}$ & 0.16 & -0.05 & -0.10 & -0.21 & $0.71^{*}$ & -0.09 & $0.60^{*}$ & $0.34^{*}$ & 0.22 & $0.59^{*}$ & $0.62^{*}$ & -0.14 \\
\hline $\mathrm{Pb}$ & $-0.46^{*}$ & -0.23 & $0.46^{*}$ & $\mathrm{x}$ & 0.07 & 0.05 & -0.06 & 0.16 & -0.20 & 0.11 & -0.01 & 0.00 & 0.18 & 0.14 & 0.10 \\
\hline $\mathrm{Cu}$ & -0.11 & 0.06 & -0.19 & 0.25 & $\mathrm{x}$ & $0.61^{*}$ & $0.42^{*}$ & -0.23 & 0.06 & $-0.40^{*}$ & -0.15 & -0.17 & $-0.28^{*}$ & $-0.38^{*}$ & 0.14 \\
\hline $\mathrm{Ni}$ & -0.01 & 0.13 & -0.25 & -0.04 & $0.51^{*}$ & $\mathrm{x}$ & 0.21 & -0.24 & 0.05 & $-0.35^{*}$ & -0.04 & -0.16 & -0.19 & $-0.31^{*}$ & 0.04 \\
\hline $\mathrm{Fe}$ & 0.28 & 0.20 & -0.12 & -0.23 & 0.16 & -0.05 & $\mathrm{x}$ & -0.20 & $0.33^{*}$ & $-0.27^{*}$ & -0.22 & -0.14 & -0.06 & $-0.26^{*}$ & -0.02 \\
\hline $\mathrm{Mg}$ & -0.30 & -0.33 & $0.81^{*}$ & $0.49^{*}$ & -0.32 & $-0.37^{*}$ & -0.17 & $\mathrm{x}$ & -0.16 & $0.88^{*}$ & $0.36^{*}$ & $0.37^{*}$ & $0.78^{*}$ & $0.88^{*}$ & $-0.27^{*}$ \\
\hline $\mathrm{K}$ & 0.09 & 0.34 & 0.16 & 0.07 & -0.01 & -0.07 & 0.17 & -0.03 & $\mathrm{x}$ & $-0.24^{*}$ & -0.08 & -0.07 & 0.03 & -0.24 & -0.06 \\
\hline $\mathrm{P}$ & -0.18 & -0.36 & $0.70^{*}$ & $0.43^{*}$ & $-0.38^{*}$ & $-0.50^{*}$ & -0.07 & $0.91^{*}$ & -0.16 & $\mathrm{x}$ & $0.37^{*}$ & $0.34^{*}$ & $0.78^{*}$ & $0.99^{*}$ & $-0.35^{*}$ \\
\hline $\mathrm{Sr}$ & -0.18 & -0.22 & $0.42^{*}$ & 0.35 & -0.21 & 0.21 & -0.19 & $0.56^{*}$ & 0.04 & $0.48^{*}$ & $\mathrm{x}$ & $0.39^{*}$ & $0.44^{*}$ & $0.36^{*}$ & $-0.37^{*}$ \\
\hline $\mathrm{Ba}$ & -0.26 & -0.31 & 0.19 & 0.03 & -0.26 & -0.18 & -0.10 & $0.38^{*}$ & -0.31 & 0.35 & 0.19 & $\mathrm{x}$ & $0.31^{*}$ & $0.33^{*}$ & -0.17 \\
\hline $\mathrm{Na}$ & 0.02 & -0.33 & $0.75^{*}$ & $0.37^{*}$ & -0.25 & $-0.41^{*}$ & 0.02 & $0.82^{*}$ & 0.09 & $0.84^{*}$ & 0.36 & 0.09 & $\mathrm{x}$ & $0.79^{*}$ & $-0.30^{*}$ \\
\hline $\mathrm{Ca}$ & -0.14 & -0.19 & $0.62^{*}$ & $0.43^{*}$ & -0.29 & -0.30 & 0.02 & $0.79^{*}$ & -0.06 & $0.86^{*}$ & $0.46^{*}$ & 0.21 & $0.71^{*}$ & $\mathrm{x}$ & $-0.37^{*}$ \\
\hline Age & $\begin{array}{c}-0.02 \\
\text { Yes }\end{array}$ & -0.03 & -0.25 & 0.09 & 0.35 & -0.03 & 0.15 & -0.21 & 0.15 & -0.07 & -0.36 & -0.05 & -0.12 & 0.03 & $\mathrm{x}$ \\
\hline
\end{tabular}

* Statistically significant.

significantly correlated positively with $\mathrm{Cu}$, and in people who drink alcohol it correlated negatively with $\mathrm{Pb}$. Iron positively correlated with age in abstainers. The heads of the femur showed a statistically significant negative correlation between $\mathrm{Cu}$ and $\mathrm{Ni}$ and the concentration of metals $(\mathrm{Ca}, \mathrm{P}, \mathrm{Mg}$, and $\mathrm{Zn}$ ) in people who drink little or average amounts, while abstainers showed no such correlation.

The changes in the femoral head between drinkers and abstainers are described by 6 important components, the total variance of which is $77.6 \%$ (Figure 8 ). The first component indicates, as above, the presence of macroelements $\mathrm{Ca}, \mathrm{P}$,
$\mathrm{Na}, \mathrm{Mg}$ and $\mathrm{Zn}$ in the structure of hydroxyapatite and, in abstainers, $\mathrm{Sr}, \mathrm{Ba}$ and $\mathrm{Na}$. The $\mathrm{Cu}, \mathrm{Cr}$, and $\mathrm{Ni}$ are characterized by the second component and these metals are opposite in drinkers and abstainers. The $\mathrm{Pb}$ in drinkers is represented by the third component.

The changes in femoral neck between drinkers and abstainers are described by 6 important components, the total variance of which is $79.1 \%$ (Figure 9). The first component indicates, as above, the presence of $\mathrm{Ca}, \mathrm{P}, \mathrm{Na}, \mathrm{Mg}$, and $\mathrm{Zn}$. Additionally, the first component indicates the content of $\mathrm{Pb}$ only in alcohol drinkers. $\mathrm{Cu}$ and $\mathrm{Ni}$ were characterized by the 
TABLE 13: Concentrations of elements (in mg/kg on dry mass basis) and differences between them in the cancellous and cortical bone of the femur according to alcohol consumption $(N=96)$.

\begin{tabular}{|c|c|c|c|c|c|c|}
\hline \multirow{5}{*}{ Alcohol } & \multirow{4}{*}{\multicolumn{3}{|c|}{$\begin{array}{c}\text { Femoral head } \\
\mathrm{AM} \pm \mathrm{SD} \\
\text { Med. } \\
\text { QL-QU }\end{array}$}} & \multirow{4}{*}{\multicolumn{3}{|c|}{$\begin{array}{c}\text { Femoral neck } \\
\mathrm{AM} \pm \mathrm{SD} \\
\text { Med. } \\
\text { QL-QU }\end{array}$}} \\
\hline & & & & & & \\
\hline & & & & & & \\
\hline & & & & & & \\
\hline & No $n=46$ & Yes $n=50$ & M-W & No $n=46$ & Yes $n=50$ & M-W \\
\hline \multirow{3}{*}{$\mathrm{Ca}$} & $136442.4 \pm 34544.3$ & $136947.8 \pm 37950.4$ & \multirow{3}{*}{ NS } & $161328.5 \pm 39085.7$ & $153425.4 \pm 41695.1$ & \multirow{3}{*}{ NS } \\
\hline & 129183 & 133763 & & 159462 & 146143 & \\
\hline & 108960-160694 & $102876-162084$ & & $128094-187160$ & $122380-181456$ & \\
\hline \multirow{3}{*}{$\mathrm{P}$} & $62247.9 \pm 16107.8$ & $63160 \pm 17517$ & \multirow{3}{*}{ NS } & $72665.4 \pm 17803.5$ & $68800.2 \pm 18692.6$ & \multirow{3}{*}{ NS } \\
\hline & 58510.4 & 61377.6 & & 71514.5 & 67434.4 & \\
\hline & $49736-76200$ & $47466-75652.4$ & & $58714-85978$ & $55156.4-82266$ & \\
\hline \multirow{3}{*}{$\mathrm{Mg}$} & $1436.1 \pm 379.2$ & $1456.6 \pm 343.3$ & \multirow{3}{*}{ NS } & $1581.4 \pm 297.8$ & $1589.8 \pm 342.6$ & \multirow{3}{*}{ NS } \\
\hline & 1340.9 & 1442.1 & & 1622 & 1566.4 & \\
\hline & $1159.1-1734$ & $1183.2-1678.6$ & & 1372.7-1740.4 & 1376.9-1853.8 & \\
\hline \multirow{3}{*}{$\mathrm{Na}$} & $5347.8 \pm 1009.6$ & $5575.7 \pm 1073$ & \multirow{3}{*}{ NS } & $4792.8 \pm 763.9$ & $4578.6 \pm 979.2$ & \multirow{3}{*}{ NS } \\
\hline & 5315 & 5649.5 & & 4862.9 & 4507.8 & \\
\hline & $4627.7-5916.2$ & 4955.9-6308.9 & & $4211-5295.8$ & $3747.7-5282.2$ & \\
\hline \multirow{3}{*}{ K } & $942.1 \pm 917$ & $750.6 \pm 348.2$ & \multirow{3}{*}{ NS } & $953.4 \pm 728.9$ & $989.4 \pm 1419.4$ & \multirow{3}{*}{ NS } \\
\hline & 694.3 & 657.15 & & 810.3 & 603 & \\
\hline & $564.4-1049.5$ & $04.9-844.7$ & & $547.2-1090$ & $450-960$ & \\
\hline \multirow{3}{*}{$\mathrm{Zn}$} & $70.02 \pm 15.65$ & $74 \pm 16.25$ & \multirow{3}{*}{ NS } & $66.99 \pm 11.9$ & $70.28 \pm 14.54$ & \multirow{3}{*}{ NS } \\
\hline & 65.58 & 75.42 & & 64.82 & 66.66 & \\
\hline & $57.68-79.47$ & $60.27-85.83$ & & $58.21-73.3$ & 59.09-76.86 & \\
\hline \multirow{3}{*}{$\mathrm{Cu}$} & $0.68 \pm 0.76$ & $1.12 \pm 0.93$ & & $0.6 \pm 0.75$ & $1.15 \pm 1.38$ & \\
\hline & 0.52 & 1.06 & $<0.05$ & 0.04 & 0.81 & $<0.05$ \\
\hline & $0.04-1.14$ & $0.04-1.75$ & & $0.04-1.03$ & $0.04-1.44$ & \\
\hline & $1.2 \pm 1.87$ & $1.45 \pm 2.56$ & & $1.47 \pm 1.76$ & $1.41 \pm 1.72$ & \\
\hline $\mathrm{Cr}$ & 0.44 & 0.5 & NS & 0.73 & 0.84 & NS \\
\hline & $0.12-1.67$ & $0.12-1.68$ & & $0.12-1.74$ & $0.12-1.58$ & \\
\hline & $0.41 \pm 0.94$ & $0.78 \pm 1.48$ & & $0.32 \pm 0.66$ & $1.21 \pm 3.05$ & \\
\hline $\mathrm{Ni}$ & 0.03 & 0.03 & $<0.05$ & 0.03 & 0.03 & NS \\
\hline & $0.03-0.39$ & $0.03-0.89$ & & $0.03-0.41$ & $0.03-0.64$ & \\
\hline & $134.38 \pm 115.12$ & $115.25 \pm 97.52$ & & $136.54 \pm 147.76$ & $126.9 \pm 132.35$ & \\
\hline $\mathrm{Fe}$ & 94.96 & 90.71 & NS & 89.54 & 95.22 & NS \\
\hline & $58.98-146.02$ & $50.43-131.18$ & & $56.15-164.75$ & $55.28-152.27$ & \\
\hline & $45.68 \pm 29.49$ & $42.42 \pm 23.52$ & & $48.05 \pm 22.78$ & $46.55 \pm 22.82$ & \\
\hline $\mathrm{Sr}$ & 35.75 & 38.31 & NS & 42.74 & 43.62 & NS \\
\hline & $25.22-50.5$ & $29.03-48.57$ & & $33.27-53.26$ & $30.53-56.15$ & \\
\hline & $0.7 \pm 0.63$ & $0.44 \pm 0.55$ & & $0.77 \pm 0.74$ & $0.7 \pm 0.62$ & \\
\hline Mo & 0.18 & 0.18 & $<0.05$ & 0.18 & 0.27 & NS \\
\hline & $0.18-1.32$ & $0.18-0.18$ & & $0.18-1.43$ & $0.18-1.33$ & \\
\hline & $2.3 \pm 1.46$ & $2.63 \pm 1.85$ & & $2.25 \pm 1.17$ & $2.56 \pm 1.41$ & \\
\hline $\mathrm{Ba}$ & 2.01 & 2.1 & NS & 1.98 & 2.42 & NS \\
\hline & $1.34-2.82$ & $1.62-3.15$ & & $1.29-3.05$ & $1.42-3.49$ & \\
\hline & $0.78 \pm 1.17$ & $1.49 \pm 1.71$ & & $0.84 \pm 1.04$ & $1.29 \pm 1.6$ & \\
\hline $\mathrm{Pb}$ & 0.32 & 0.32 & $<0.05$ & 0.32 & 0.32 & NS \\
\hline & $0.32-0.32$ & $0.32-2.71$ & & $0.32-1.17$ & $0.32-1.99$ & \\
\hline
\end{tabular}

AM: arithmetic mean; SD: standard deviation; Med: median; QL: lower quartile; QU: upper quartile; M-W: Mann-Whitney U-test; $p$ : level of significance; NS: nonsignificant difference. 


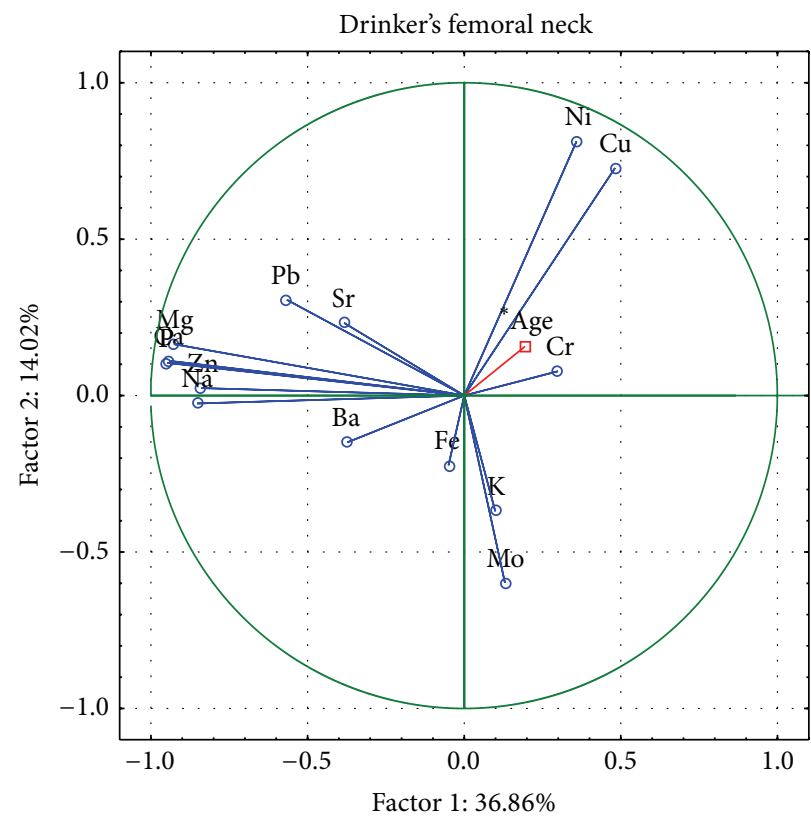

Octive

$\square$ Add.

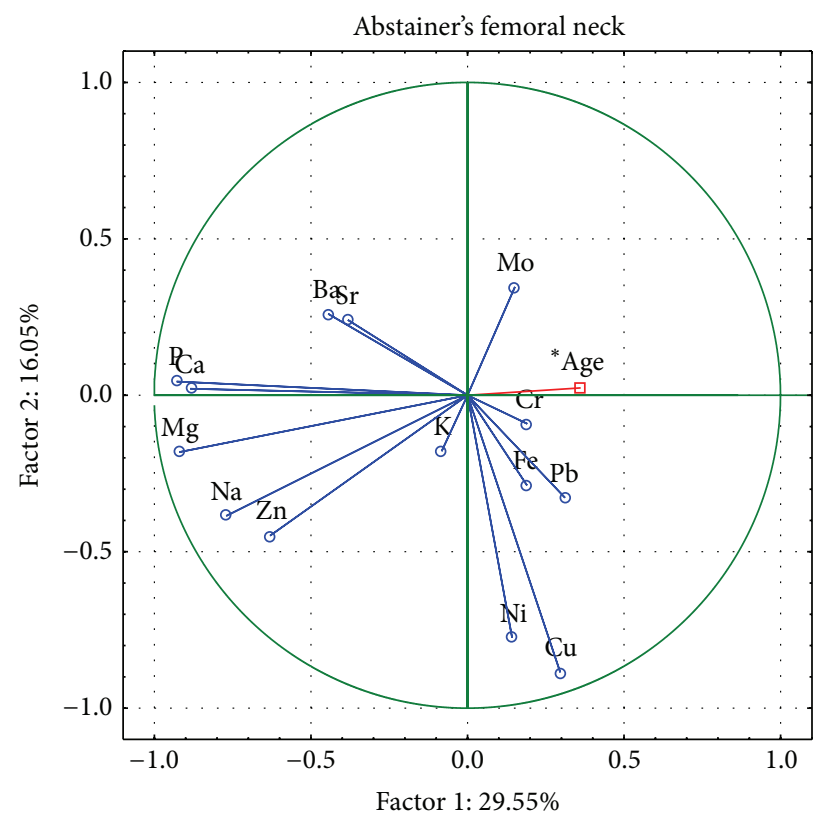

Active

$\square$ Add.

Figure 8: A graphic illustration of Principal Components Analysis of contents of elements according to alcohol consumption for femoral neck. Projection of the variables on the factor plane of the first two principal components for alcohol drinkers and abstainers.

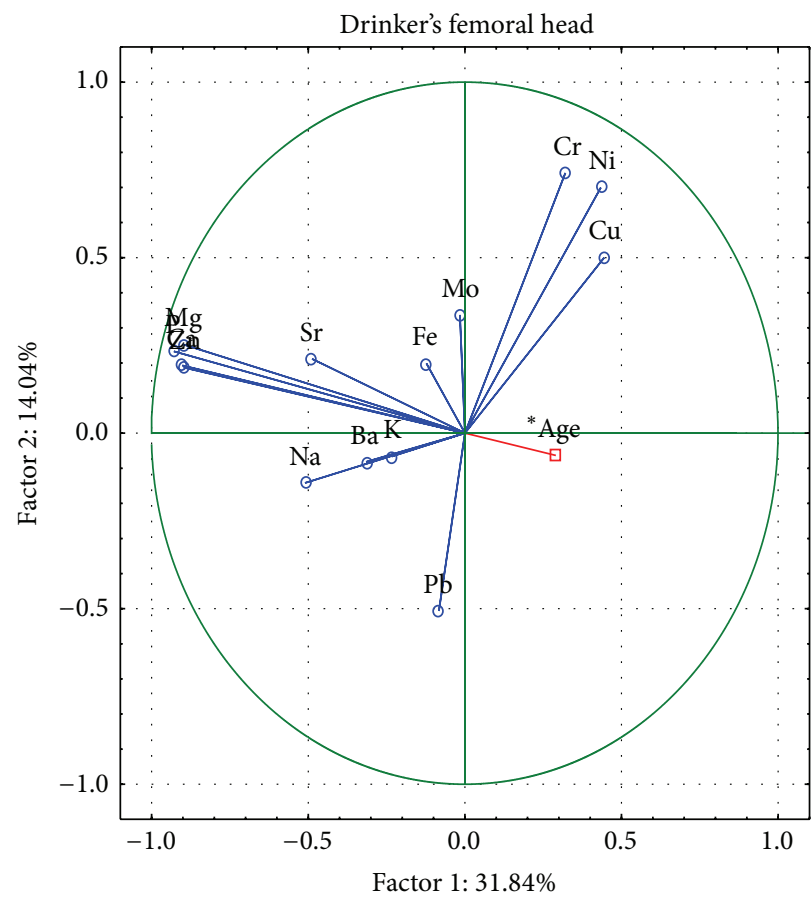

O Active

$\square$ Add.

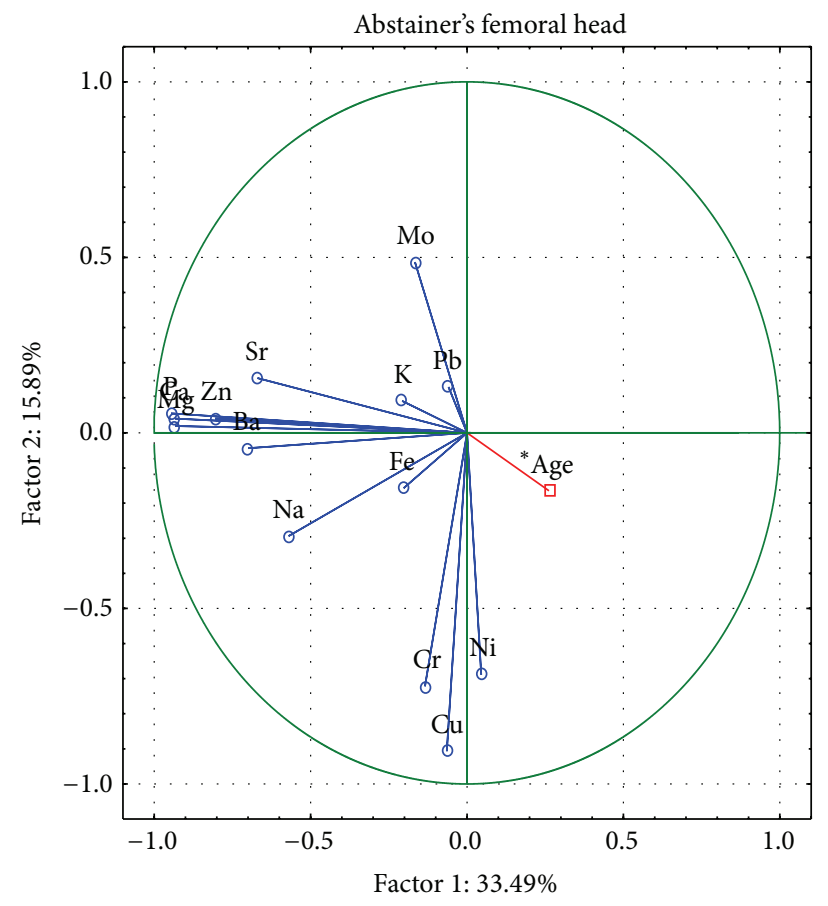

O Active

$\square$ Add.

Figure 9: A graphic illustration of Principal Components Analysis of contents of elements according to alcohol consumption for femoral head. Projection of the variables on the factor plane of the first two principal components for alcohol drinkers and abstainers. 
TABLE 14: Spearman correlation coefficients for metals found in femoral neck of alcohol drinkers and abstainers.

\begin{tabular}{|c|c|c|c|c|c|c|c|c|c|c|c|c|c|c|c|}
\hline $\begin{array}{l}\text { Neck } \\
\text { Alcohol }\end{array}$ & $\begin{array}{l}\text { Mo } \\
\text { Yes }\end{array}$ & $\mathrm{Cr}$ & $\mathrm{Zn}$ & $\mathrm{Pb}$ & $\mathrm{Cu}$ & $\mathrm{Ni}$ & $\mathrm{Fe}$ & $\mathrm{Mg}$ & $\mathrm{K}$ & $\mathrm{P}$ & $\mathrm{Sr}$ & $\mathrm{Ba}$ & $\mathrm{Na}$ & $\mathrm{Ca}$ & Age \\
\hline Mo & $\mathrm{x}$ & -0.02 & 0.10 & $-0.37^{*}$ & -0.12 & -0.11 & -0.06 & -0.26 & 0.02 & -0.11 & -0.14 & -0.06 & 0.00 & -0.13 & 0.02 \\
\hline $\mathrm{Cr}$ & 0.23 & $\mathrm{x}$ & -0.13 & $-0.30^{*}$ & 0.27 & $0.35^{*}$ & 0.26 & -0.19 & 0.26 & $-0.32^{*}$ & -0.11 & $-0.30^{*}$ & -0.22 & $-0.31^{*}$ & -0.02 \\
\hline $\mathrm{Zn}$ & -0.17 & 0.03 & $\mathrm{x}$ & $0.40^{*}$ & $-0.41^{*}$ & $-0.31^{*}$ & -0.11 & $0.82^{*}$ & 0.04 & $0.75^{*}$ & $0.42^{*}$ & 0.24 & $0.77^{*}$ & $0.75^{*}$ & -0.08 \\
\hline $\mathrm{Pb}$ & -0.27 & -0.05 & 0.07 & $\mathrm{x}$ & -0.10 & -0.21 & -0.18 & $0.50^{*}$ & 0.00 & $0.48^{*}$ & $0.32^{*}$ & 0.21 & $0.41^{*}$ & $0.48^{*}$ & -0.03 \\
\hline $\mathrm{Cu}$ & -0.22 & 0.28 & 0.14 & $0.35^{*}$ & $\mathrm{x}$ & $0.57^{*}$ & 0.20 & $-0.36^{*}$ & -0.09 & $-0.42^{*}$ & -0.12 & -0.22 & $-0.37^{*}$ & $-0.41^{*}$ & 0.26 \\
\hline $\mathrm{Ni}$ & 0.07 & 0.26 & 0.00 & 0.28 & $0.56^{*}$ & $\mathrm{x}$ & -0.05 & $-0.41^{*}$ & -0.14 & $-0.45^{*}$ & 0.16 & $-0.31^{*}$ & $-0.39^{*}$ & $-0.41^{*}$ & -0.03 \\
\hline $\mathrm{Fe}$ & 0.03 & $0.48^{*}$ & -0.21 & -0.03 & $0.53^{*}$ & $0.39^{*}$ & $\mathrm{x}$ & -0.01 & 0.18 & -0.05 & -0.17 & -0.03 & 0.08 & -0.07 & -0.01 \\
\hline $\mathrm{Mg}$ & -0.05 & 0.04 & $0.65^{*}$ & -0.04 & -0.19 & -0.11 & $-0.37^{*}$ & $\mathrm{x}$ & -0.08 & $0.91^{*}$ & $0.48^{*}$ & $0.38^{*}$ & $0.81^{*}$ & $0.90^{*}$ & -0.11 \\
\hline K & -0.09 & $0.32^{*}$ & -0.05 & -0.20 & 0.26 & 0.18 & $0.41^{*}$ & -0.22 & $\mathrm{x}$ & -0.18 & -0.01 & & 0.07 & -0 & 0.20 \\
\hline $\mathrm{P}$ & -0.10 & -0.05 & $0.51^{*}$ & -0.10 & $-0.33^{*}$ & $-0.29^{*}$ & $-0.41^{*}$ & $0.88^{*}$ & $-0.32^{*}$ & $\mathrm{x}$ & $0.50^{*}$ & $0.38^{*}$ & $0.85^{*}$ & $0.98^{*}$ & -0.11 \\
\hline $\mathrm{Sr}$ & 0.06 & 0.00 & $0.30^{*}$ & -0.21 & -0.24 & -0.16 & -0.25 & $0.35^{*}$ & -0.12 & 0.29 & $\mathrm{x}$ & 0.20 & $0.44^{*}$ & $0.53^{*}$ & -0.26 \\
\hline $\mathrm{Ba}$ & 0.14 & 0.19 & 0.20 & $-0.32^{*}$ & -0.25 & -0.03 & -0.23 & $0.34^{*}$ & -0.02 & $0.33^{*}$ & $0.46^{*}$ & $\mathrm{x}$ & 0.22 & $0.39^{*}$ & -0.26 \\
\hline $\mathrm{Na}$ & -0.14 & 0.09 & $0.50^{*}$ & 0.01 & -0.12 & -0.06 & -0.17 & $0.77^{*}$ & 0.00 & $0.74^{*}$ & $0.39^{*}$ & 0.28 & $\mathrm{x}$ & $0.82^{*}$ & -0.07 \\
\hline $\mathrm{Ca}$ & -0.03 & 0.04 & $0.50^{*}$ & -0.10 & $-0.30^{*}$ & -0.18 & $-0.31^{*}$ & $0.82^{*}$ & -0.28 & $0.92^{*}$ & 0.21 & 0.27 & $0.69^{*}$ & $\mathrm{x}$ & -0.13 \\
\hline Age & $\begin{array}{c}-0.01 \\
\text { No }\end{array}$ & -0.04 & -0.20 & $0.31^{*}$ & 0.17 & 0.04 & 0.00 & $-0.36^{*}$ & -0.10 & $-0.40^{*}$ & $-0.34^{*}$ & -0.02 & $-0.39^{*}$ & $-0.38^{*}$ & $\mathrm{x}$ \\
\hline
\end{tabular}

${ }^{*}$ Statistically significant.

TABLE 15: Spearman correlation coefficients for metals found in femoral head of alcohol drinkers and abstainers.

\begin{tabular}{|c|c|c|c|c|c|c|c|c|c|c|c|c|c|c|c|}
\hline $\begin{array}{l}\text { Head } \\
\text { Alcohol }\end{array}$ & $\begin{array}{l}\text { Mo } \\
\text { Yes }\end{array}$ & $\mathrm{Cr}$ & $\mathrm{Zn}$ & $\mathrm{Pb}$ & $\mathrm{Cu}$ & $\mathrm{Ni}$ & $\mathrm{Fe}$ & $\mathrm{Mg}$ & $\mathrm{K}$ & $\mathrm{P}$ & $\mathrm{Sr}$ & $\mathrm{Ba}$ & $\mathrm{Na}$ & $\mathrm{Ca}$ & Age \\
\hline Mo & $\mathrm{x}$ & 0.14 & 0.15 & 0.02 & 0.01 & -0.05 & $0.28^{*}$ & 0.07 & 0.17 & 0.05 & -0.04 & 0.00 & -0.03 & -0.06 & 0.14 \\
\hline $\mathrm{Cr}$ & -0.26 & $\mathrm{x}$ & 0.00 & $-0.32^{*}$ & $0.34^{*}$ & 0.12 & $0.28^{*}$ & 0.09 & 0.10 & 0.09 & -0.04 & -0.07 & 0.05 & 0.08 & 0.00 \\
\hline $\mathrm{Zn}$ & 0.14 & -0.10 & $\mathrm{x}$ & 0.06 & -0.28 & $-0.33^{*}$ & 0.16 & $0.86^{*}$ & 0.14 & $0.87^{*}$ & $0.59^{*}$ & $0.38^{*}$ & $0.38^{*}$ & $0.84^{*}$ & -0.24 \\
\hline $\mathrm{Pb}$ & 0.17 & 0.00 & 0.00 & $\mathrm{x}$ & -0.08 & -0.17 & 0.01 & 0.02 & 0.11 & -0.04 & -0.07 & 0.02 & $0.30^{*}$ & 0.03 & 0.13 \\
\hline $\mathrm{Cu}$ & $-0.39^{*}$ & $0.53^{*}$ & 0.01 & -0.13 & $\mathrm{x}$ & $0.51^{*}$ & 0.08 & -0.24 & 0.14 & $-0.31^{*}$ & -0.16 & $-0.29^{*}$ & $-0.30^{*}$ & $-0.29^{*}$ & 0.08 \\
\hline $\mathrm{Ni}$ & -0.04 & 0.24 & 0.04 & 0.14 & 0.25 & $\mathrm{x}$ & -0.23 & $-0.31^{*}$ & $-0.33^{*}$ & $-0.36^{*}$ & -0.17 & 0.04 & $-0.36^{*}$ & $-0.36^{*}$ & 0.11 \\
\hline $\mathrm{Fe}$ & -0.19 & $0.41^{*}$ & 0.14 & 0.09 & $0.29^{*}$ & -0.06 & $\mathrm{x}$ & 0.10 & $0.28^{*}$ & 0.19 & -0.09 & 0.01 & 0.15 & 0.08 & -0.11 \\
\hline $\mathrm{Mg}$ & 0.08 & 0.04 & $0.72^{*}$ & 0.05 & 0.12 & 0.05 & -0.02 & $\mathrm{x}$ & 0.17 & $0.91^{*}$ & $0.57^{*}$ & $0.41^{*}$ & 0.26 & $0.88^{*}$ & -0.17 \\
\hline $\mathrm{K}$ & -0.07 & 0.26 & 0.12 & -0.07 & $0.36^{*}$ & -0.16 & $0.31^{*}$ & 0.24 & $\mathrm{x}$ & 0.08 & $0.29^{*}$ & -0.19 & $0.39^{*}$ & 0.00 & 0.08 \\
\hline $\mathrm{P}$ & 0.11 & -0.02 & $0.75^{*}$ & 0.08 & 0.04 & 0.11 & 0.02 & $0.91^{*}$ & 0.17 & $\mathrm{x}$ & $0.53^{*}$ & $0.44^{*}$ & $0.36^{*}$ & $0.95^{*}$ & -0.15 \\
\hline $\mathrm{Sr}$ & 0.11 & -0.12 & $0.48^{*}$ & -0.06 & -0.03 & 0.02 & 0.04 & $0.60^{*}$ & 0.27 & $0.60^{*}$ & $\mathrm{x}$ & $0.28^{*}$ & $0.30^{*}$ & $0.55^{*}$ & -0.12 \\
\hline $\mathrm{Ba}$ & 0.03 & 0.21 & $0.34^{*}$ & 0.04 & 0.02 & 0.02 & -0.04 & $0.55^{*}$ & 0.16 & $0.49^{*}$ & $0.53^{*}$ & $\mathrm{x}$ & 0.09 & $0.41^{*}$ & -0.20 \\
\hline $\mathrm{Na}$ & -0.22 & 0.17 & $0.39^{*}$ & -0.08 & $0.36^{*}$ & -0.03 & 0.12 & $0.48^{*}$ & $0.58^{*}$ & $0.44^{*}$ & $0.44^{*}$ & $0.35^{*}$ & $\mathrm{x}$ & $0.32^{*}$ & 0.00 \\
\hline $\mathrm{Ca}$ & 0.12 & -0.03 & $0.76^{*}$ & 0.10 & 0.04 & 0.13 & 0.02 & $0.90^{*}$ & 0.15 & $0.99^{*}$ & $0.59^{*}$ & $0.46^{*}$ & $0.39^{*}$ & $\mathrm{x}$ & -0.11 \\
\hline Age & $\begin{array}{c}-0.08 \\
\text { No }\end{array}$ & 0.21 & -0.09 & 0.05 & 0.11 & -0.11 & $0.36^{*}$ & -0.23 & 0.07 & -0.28 & -0.16 & 0.06 & -0.20 & -0.26 & $\mathrm{x}$ \\
\hline
\end{tabular}

${ }^{*}$ Statistically significant.

second component and $\mathrm{Cr}$ by the third component, but the values of these components were opposite in drinkers and in abstainers.

3.1.5. Residence-Related Differences. The analysis with the Mann-Whitney $U$-test showed no statistically significant differences in the concentrations of the examined metals in the cortical and cancellous bone between patients living in villages and those living in cities (Table 16).

Previous studies described the existence of heavy metals in several regions of Poland. Jurkiewicz et al. [34] evaluated the similar content of $\mathrm{Ca}, \mathrm{P}, \mathrm{Mg}, \mathrm{P}, \mathrm{Fe}, \mathrm{Zn}, \mathrm{Cu}, \mathrm{Pb}, \mathrm{Cd}, \mathrm{As}$, and $\mathrm{Ag}$ in femoral heads of inhabitants of southern Poland (Silesia, Cracow) and middle Poland (Łódź). Specimens from different regions differed in $\mathrm{Pb}$ and $\mathrm{Cd}$ content, illustrating the differences in environmental pollution exposure [26]. Budis et al. [18] found no statistically significant residencerelated differences in the concentrations of $\mathrm{Sr}, \mathrm{Mn}$, or Fe.

3.1.6. Age. To determine the differences in the content of various elements in the femur samples in different age groups, the Kruskal-Wallis test was used. A marked tendency to 
TABLE 16: Concentrations of elements (in $\mathrm{mg} / \mathrm{kg}$ on dry mass basis) and differences between them in the cancellous and cortical bone of the femur in according place of residence $(N=96)$.

\begin{tabular}{|c|c|c|c|c|c|c|}
\hline & & moral head & & & noral neck & \\
\hline & & $\mathrm{AM} \pm \mathrm{SD}$ & & & $M \pm S D$ & \\
\hline & & Med. & & & Med. & \\
\hline & & QL-QU & & & QL-QU & \\
\hline & Villages $n=24$ & Cities $n=72$ & M-W & Villages $n=24$ & Cities $n=72$ & M-W \\
\hline & $133711.4 \pm 36808.1$ & $137703.7 \pm 36158.5$ & & $165008.1 \pm 51281.2$ & $154613.7 \pm 36191.7$ & \\
\hline $\mathrm{Ca}$ & 120389 & 137906 & NS & 150816 & 153269 & NS \\
\hline & $101795-166517$ & $108575-159925$ & & $125282-215620$ & $128031-175956$ & \\
\hline & $61471.6 \pm 17252.3$ & $63140.1 \pm 16714.3$ & & $74568.7 \pm 22839.8$ & $69346.8 \pm 16467.5$ & \\
\hline $\mathrm{P}$ & 55552.4 & 60363.1 & NS & 67228.7 & 69616.2 & NS \\
\hline & $46500.6-77052$ & 49964-75566.2 & & 57776.1-98764.2 & $57515-78448$ & \\
\hline & $1391.2 \pm 332.4$ & $1465.3 \pm 368$ & & $1579.8 \pm 362.9$ & $1587.8 \pm 307.5$ & \\
\hline $\mathrm{Mg}$ & 1325.7 & 1385.8 & NS & 1583.3 & 1595.3 & NS \\
\hline & 1103.1-1585.4 & $1202.8-1761.1$ & & 1348.2-1781.9 & $1385.2-1792.1$ & \\
\hline & $5467.9 \pm 1128$ & $5466.1 \pm 1022.8$ & & $4660.3 \pm 904.9$ & $4688.2 \pm 884.1$ & \\
\hline $\mathrm{Na}$ & 5461.7 & 5428.6 & NS & 4845.9 & 4642.6 & NS \\
\hline & $4790.7-6362.5$ & $4700.2-6086$ & & $4121.8-5297.7$ & $4020.9-5289$ & \\
\hline & $1002.9 \pm 1178.6$ & $788.9 \pm 409.2$ & & $835.1 \pm 505.6$ & $1017.8 \pm 1279.2$ & \\
\hline $\mathrm{K}$ & 711.4 & 657.1 & NS & 629 & 655 & NS \\
\hline & $534.7-892.7$ & $522.2-971.1$ & & 482.3-1049.7 & 502.4-995 & \\
\hline & $69.97 \pm 16.17$ & $72.8 \pm 16$ & & $70.05 \pm 17.61$ & $68.25 \pm 11.75$ & \\
\hline $\mathrm{Zn}$ & 67.13 & 71.01 & NS & 66.55 & 66.21 & NS \\
\hline & 59.73-79.74 & $60.17-86.07$ & & $57.08-81.27$ & $60.18-75.31$ & \\
\hline & $0.8 \pm 0.83$ & $0.95 \pm 0.9$ & & $1.03 \pm 1.45$ & $0.84 \pm 1.04$ & \\
\hline $\mathrm{Cu}$ & 0.73 & 0.87 & NS & 0.75 & 0.69 & NS \\
\hline & $0.04-1.06$ & $0.04-1.55$ & & $0.04-1.3$ & $0.04-1.15$ & \\
\hline & $1.11 \pm 1.36$ & $1.41 \pm 2.47$ & & $0.82 \pm 0.83$ & $1.65 \pm 1.9$ & \\
\hline $\mathrm{Cr}$ & 0.47 & 0.49 & NS & 0.66 & 0.85 & NS \\
\hline & $0.12-1.69$ & $0.12-1.59$ & & $0.12-1.17$ & $0.24-2.32$ & \\
\hline & $0.68 \pm 1.68$ & $0.57 \pm 1.1$ & & $0.93 \pm 3.01$ & $0.74 \pm 2$ & \\
\hline $\mathrm{Ni}$ & 0.03 & 0.03 & NS & 0.03 & 0.03 & NS \\
\hline & $0.03-0.44$ & $0.03-0.74$ & & $0.03-0.46$ & $0.03-0.52$ & \\
\hline & $141.86 \pm 119.1$ & $118.6 \pm 101.75$ & & $105.95 \pm 74.64$ & $140.04 \pm 154.46$ & \\
\hline $\mathrm{Fe}$ & 123.51 & 90.71 & NS & 84.44 & 96.14 & NS \\
\hline & 50.45-182.49 & $55.34-123.84$ & & 42.47-173.09 & 63.75-144.17 & \\
\hline & $44.13 \pm 27.28$ & $43.93 \pm 26.37$ & & $50.49 \pm 23.18$ & $46.19 \pm 22.59$ & \\
\hline $\mathrm{Sr}$ & 36.75 & 36.34 & NS & 52.22 & 42.39 & NS \\
\hline & $24.16-59.66$ & $26.56-47.53$ & & $29.18-62.26$ & $32.35-49.08$ & \\
\hline & $0.54 \pm 0.59$ & $0.57 \pm 0.61$ & & $0.55 \pm 0.56$ & $0.79 \pm 0.71$ & \\
\hline Mo & 0.18 & 0.18 & NS & 0.18 & 0.36 & NS \\
\hline & $0.18-1.24$ & $0.18-1.12$ & & $0.18-1.15$ & $0.18-1.41$ & \\
\hline & $2.3 \pm 1.57$ & $2.53 \pm 1.72$ & & $2.24 \pm 1.15$ & $2.47 \pm 1.35$ & \\
\hline $\mathrm{Ba}$ & 1.98 & 2.09 & NS & 2.06 & 2.28 & NS \\
\hline & $1.41-2.56$ & $1.46-3.14$ & & $1.32-2.71$ & $1.41-3.35$ & \\
\hline & $1.03 \pm 1.67$ & $1.19 \pm 1.47$ & & $1.16 \pm 1.34$ & $1.05 \pm 1.39$ & \\
\hline $\mathrm{Pb}$ & 0.32 & 0.32 & NS & 0.32 & 0.32 & NS \\
\hline & $0.32-0.32$ & $0.32-2.01$ & & $0.32-1.9$ & $0.32-1.32$ & \\
\hline
\end{tabular}

AM: arithmetic mean; SD: standard deviation; Med.: median; QL: lower quartile; QU: upper quartile; M-W, Mann-Whitney U-test; $p$ : level of significance; NS: nonsignificant difference. 
TABLE 17: Concentrations of elements (in $\mathrm{mg} / \mathrm{kg}$ on dry mass basis) and differences between them in the cancellous and cortical bone of the femur according to age $(N=96)$.

\begin{tabular}{|c|c|c|c|c|c|}
\hline & \multicolumn{5}{|c|}{ Age group } \\
\hline & \multicolumn{5}{|c|}{$\mathrm{AM} \pm \mathrm{SD}$} \\
\hline & \multicolumn{5}{|c|}{ Med. } \\
\hline & \multicolumn{5}{|c|}{ QL-QU } \\
\hline & $20-50$ & $51-60$ & $61-70$ & $71-80$ & $>80$ \\
\hline & $n=11$ & $n=27$ & $n=30$ & $n=18$ & $n=10$ \\
\hline \multirow{3}{*}{$\begin{array}{l}\mathrm{Ca} \\
\mathrm{FH}^{*}\end{array}$} & $158198.7 \pm 38763.7$ & $128491.7 \pm 32287.9$ & $142865.8 \pm 41041.9$ & $136323.9 \pm 30232.2$ & $117447.4 \pm 25831.3$ \\
\hline & 158656 & 119666 & 136459 & 135038 & 121188 \\
\hline & 119568-194996 & 104066-158906 & $104148-180870$ & $112362-158708$ & 92534-138612 \\
\hline \multirow{3}{*}{$\begin{array}{l}\mathrm{P} \\
\mathrm{FH}\end{array}$} & $72958.8 \pm 17399.0$ & $59432.8 \pm 15271.7$ & $65732 \pm 18749.4$ & $61975.2 \pm 14169.0$ & $52665.89 \pm 11992.4$ \\
\hline & 71803.96 & 54516.5 & 63332 & 62014.79 & 53548.95 \\
\hline & $56613.8-92310.8$ & $48103.8-72450.9$ & $47194-81518$ & 50192.0-73190.1 & $40807.6-59649.0$ \\
\hline \multirow{3}{*}{$\begin{array}{l}\mathrm{Mg} \\
\mathrm{FH}\end{array}$} & $1675.5 \pm 264.4$ & $1357.3 \pm 311.6$ & $1511.3 \pm 382.9$ & $1452.2 \pm 379.6$ & $1232.7 \pm 325.1$ \\
\hline & 1734.02 & 1224.56 & 1481.88 & 1350.05 & 1299.93 \\
\hline & $1521.88-1919.11$ & $1112.9-1607.55$ & $1200.59-1784.71$ & 1261.19-1635.77 & $912.79-1380.28$ \\
\hline \multirow{3}{*}{$\begin{array}{l}\mathrm{Sr} \\
\mathrm{FH}\end{array}$} & $57.38 \pm 44.36$ & $38.93 \pm 13.78$ & $51.54 \pm 32.58$ & $36.22 \pm 14.79$ & $34.16 \pm 10.28$ \\
\hline & 42 & 40.48 & 36.34 & 34.31 & 33.41 \\
\hline & $24.48-87.53$ & $24.83-46.18$ & $29.07-60.9$ & $25.47-42.93$ & $26.96-43.55$ \\
\hline \multirow{3}{*}{$\begin{array}{l}\mathrm{Ca} \\
\mathrm{FN}^{* *}\end{array}$} & $168736.1 \pm 46354.7$ & $164040.1 \pm 33363.7$ & $163121.1 \pm 45040.8$ & $149062.8 \pm 37371.2$ & $123043.4 \pm 25357.7$ \\
\hline & 176572 & 162990 & 162856 & 152295 & 127221 \\
\hline & $125302-214280$ & 134490-200640 & 128094-209680 & $121488-174288$ & 101530-141492 \\
\hline \multirow{3}{*}{$\begin{array}{l}\mathrm{P} \\
\mathrm{FN}\end{array}$} & $77115.9 \pm 21627.3$ & $73381.2 \pm 14886.5$ & $73111.8 \pm 19676.9$ & $66838.4 \pm 17941.8$ & $55660.2 \pm 11790.0$ \\
\hline & 82532.67 & 71312.87 & 72363.86 & 67434.43 & 57634.75 \\
\hline & 54786.4-101807.6 & $60465.3-85978$ & 57948.0-88971.4 & $55192.08-78304$ & $45022-64054.72$ \\
\hline \multirow{3}{*}{$\begin{array}{l}\mathrm{Mg} \\
\mathrm{FN}\end{array}$} & $1636.91 \pm 307.05$ & $1660.16 \pm 272.33$ & $1631.32 \pm 358.02$ & $1501.81 \pm 305.75$ & $1343.52 \pm 260.56$ \\
\hline & 1544.1 & 1681.6 & 1654.69 & 1507.45 & 1397.65 \\
\hline & 1410.69-1910.4 & 1478.3-1793.73 & $1372.67-1865.9$ & $1283.17-1642.48$ & $1175.38-1534.37$ \\
\hline \multirow{3}{*}{$\begin{array}{l}\mathrm{Sr} \\
\mathrm{FN}\end{array}$} & $60.53 \pm 35.13$ & $49.33 \pm 21.89$ & $50.53 \pm 22.6$ & $36.52 \pm 12.22$ & $36.64 \pm 11.51$ \\
\hline & 52.54 & 44.62 & 44.97 & 37.96 & 34.37 \\
\hline & $31.68-80.56$ & $33.76-57.13$ & $34.22-62.84$ & $27.18-44.08$ & $25.64-44.54$ \\
\hline
\end{tabular}

${ }^{*}$ FH: femoral head; ${ }^{* *}$ FN: femoral neck; AM: arithmetic mean; SD: standard deviation; Med.: median; QL: lower quartile; QU: upper quartile.

decrease the concentration of structural elements with age has been shown by a statistical significance for femoral head $\mathrm{Ca}, \mathrm{P}$, and $\mathrm{Mg}$. We also found significant reductions in the concentration of Sr with age in the femoral neck.

A statistically significant tendency for the $\mathrm{Ca}, \mathrm{Mg}$, and $\mathrm{P}$ content to decrease with age was found in the human rib bone, regardless of gender (Table 17). The mass fraction of $\mathrm{Fe}$ in the male rib bone increases with age. Higher $\mathrm{Ca}$, $\mathrm{Mg}, \mathrm{Na}, \mathrm{P}$, and $\mathrm{Sr}$ mass fractions and lower $\mathrm{Fe}$ content were typical of female ribs compared to male ribs $[6,44]$. Previous research indicates that trace metal concentrations of $\mathrm{Zn}$ and $\mathrm{Sr}$ decrease with age [45]. Conversely, only $\mathrm{Pb}$ is shown to increase with age, which was previously attributed to higher $\mathrm{Pb}$ exposure in the past. Alternatively, the higher $\mathrm{Pb}$ concentrations may indicate additional exposure over time that exceeds endogenous release during bone remodeling, that is, an accumulation of $\mathrm{Pb}[32]$.

\section{Conclusions}

The standard deviations obtained for all trace elements are, respectively, large. This finding is attributable to the wide individual variation of trace element mass fractions in the human femoral bone affected by osteoarthritis. The factors that most affect the content and interactions of the elements in the femoral head and neck are smoking (increased content of chromium and nickel in smokers), alcohol consumption (higher concentration of nickel and copper in people consuming alcohol), and gender (higher concentrations of nickel, copper, and zinc in men). We confirmed significant differences in the content of metals between cancellous and cortical bone. The factors contributing to the toxic accumulation of lead in bone tissue are smoking, consumption of alcohol, male gender, and age. The concentrations of calcium, phosphorus, magnesium, and strontium decrease with age 
and the concentration of lead increases with age. Loss of elements, calcium, phosphorus, magnesium, zinc, sodium, and strontium from the femoral neck, progresses with age and is more common in city dwellers and those who are physically inactive. Radiological and clinical factors (pain, BMI, and cortical index) do not correlate significantly with the contents of the elements in the femur.

\section{Highlights}

(i) We found a significantly higher content of $\mathrm{Cu}, \mathrm{Ni}$, and $\mathrm{Pb}$ in drinkers.

(ii) In the femoral neck, Cr strongly positively correlated with $\mathrm{Ni}$ in smokers.

(iii) We determined that cigarette smoking, alcohol consumption, and gender were the most influential factors.

(iv) We observed much higher concentrations of $\mathrm{Zn}, \mathrm{Cu}$, $\mathrm{Ni}$, and $\mathrm{Pb}$ in the femoral head in men.

(v) We identified a higher Ni content in people who had contact with chemicals.

\section{Disclosure}

All the other authors have read the paper and have agreed to submit it in its current form for consideration for publication in the journal.

\section{Conflict of Interests}

The authors declare that they have no conflict of interests.

\section{Acknowledgment}

The research was supported by the Faculty of Chemistry, Adam Mickiewicz University in Poznań, Poland.

\section{References}

[1] M. Berglund, A. Åkesson, P. Bjellerup, and M. Vahter, "Metalbone interactions," Toxicology Letters, vol. 112-113, pp. 219-225, 2000.

[2] E. Hodgson, "Introduction to toxicology 3," in A Textbook of Modern Toxicology, Wiley, 4th edition, 2010.

[3] R. A. Goyer, “Toxic and essential metal interactions," Annual Review of Nutrition, vol. 17, no. 1, pp. 37-50, 1997.

[4] B. A. Fowler, G. F. Nordberg, M. Nordberg, and L. Friberg, Handbook on the Toxicology of Metals, Elsevier, New York, NY, USA, 2011.

[5] M. J. Glimcher, "Bone: nature of the calcium phosphate crystals and cellular, structural, and physical chemical mechanisms in their formation," Reviews in Mineralogy and Geochemistry, vol. 64, no. 1, pp. 223-282, 2006.

[6] S. Zaichick, V. Zaichick, V. K. Karandashev, and I. R. Moskvina, "The effect of age and gender on 59 trace-element contents in human rib bone investigated by inductively coupled plasma mass spectrometry," Biological Trace Element Research, vol. 143, no. 1, pp. 41-57, 2011.
[7] S. Boonen, J. Aerssens, J. Dequeker et al., "Age-associated decline in human femoral neck cortical and trabecular content of insulin-like growth factor I: potential implications for agerelated (type II) osteoporotic fracture occurrence," Calcified Tissue International, vol. 61, no. 3, pp. 173-178, 1997.

[8] I. A. Bergdahl, U. Strömberg, L. Gerhardsson, A. Schütz, D. R. Chettle, and S. Skerfving, "Lead concentrations in tibial and calcaneal bone in relation to the history of lead exposure," Scandinavian Journal of Work, Environment \& Health, vol. 24, no. 1 , pp. 38-45, 1998.

[9] N. W. Solomons, "Update on zinc biology," Annals of Nutrition and Metabolism, vol. 62, supplement 1, pp. 8-17, 2013.

[10] R. T. Hamza, A. I. Hamed, and M. T. Sallam, "Effect of zinc supplementation on growth Hormone Insulin growth factor axis in short Egyptian children with zinc deficiency," Italian Journal of Pediatrics, vol. 38, no. 1, article 21, 2012.

[11] L. Fong, K. Tan, C. Tran et al., "Interaction of dietary zinc and intracellular binding protein metallothionein in postnatal bone growth," Bone, vol. 44, no. 6, pp. 1151-1162, 2009.

[12] E. Hesse, R. Kiviranta, M. Wu et al., "Zinc finger protein 521, a new player in bone formation," Annals of the New York Academy of Sciences, vol. 1192, pp. 32-37, 2010.

[13] B. Brodziak-Dopierała, A. Paukszto, J. Kowol, M. Bogunia, and B. Ahnert, "Interactions of copper and iron with other elements in the osseous tissue of the femur head," Fresenius Environmental Bulletin, vol. 18, no. 10, pp. 1963-1966, 2009.

[14] D. L. de Romaña, M. Olivares, R. Uauy, and M. Araya, "Risks and benefits of copper in light of new insights of copper homeostasis," Journal of Trace Elements in Medicine and Biology, vol. 25, no. 1, pp. 3-13, 2011.

[15] T. Okano, "Effects of essential trace elements on bone turnover-in relation to the osteoporosis," Japanese Journal of Clinical Medicine, vol. 54, no. 1, pp. 148-154, 1996.

[16] A. Kabata-Pendias and A. B. Mukherjee, Trace Elements from Soil to Human, Springer, 2007.

[17] E. D. Weinberg, “The hazards of iron loading," Metallomics, vol. 2, no. 11, pp. 732-740, 2010.

[18] H. Budis, E. Kalisinska, N. Lanocha et al., "The concentration of manganese, iron, and strontium in hip joint bone obtained from patients undergoing hip replacement surgery," Journal of Trace Elements in Medicine and Biology, vol. 28, no. 1, pp. 39-44, 2014.

[19] Z. Saidak and P. J. Marie, "Strontium signaling: molecular mechanisms and therapeutic implications in osteoporosis," Pharmacology and Therapeutics, vol. 136, no. 2, pp. 216-226, 2012.

[20] A. C. Ross, Modern Nutrition in Health and Disease, Wolters Kluwer Health/Lippincott Williams \& Wilkins, 2012.

[21] M. Cempel and G. Nikel, "Nickel: a review of its sources and environmental toxicology," Polish Journal of Environmental Studies, vol. 15, no. 3, pp. 375-382, 2006.

[22] B. Brodziak-Dopierała, J. Kwapuliński, K. Sobczyk, and J. Kowol, "The occurrence of nickel and other elements in tissues of the hip joint," Ecotoxicology and Environmental Safety, vol. 74, no. 4, pp. 630-635, 2011.

[23] H. A. Godwin, "The biological chemistry of lead," Current Opinion in Chemical Biology, vol. 5, no. 2, pp. 223-227, 2001.

[24] E. K. Jaffe, J. Martins, J. Li, J. Kervinen, and R. L. Dunbrack Jr., "The molecular mechanism of lead inhibition of human porphobilinogen synthase," The Journal of Biological Chemistry, vol. 276, no. 2, pp. 1531-1537, 2001. 
[25] B. Brodziak-Dopierała, J. Kwapuliński, Z. Gajda, J. Toborek, and M. Bogunia, "Changes of heavy metal concentrations in cross-sections of human femur head," Biological Trace Element Research, vol. 114, no. 1-3, pp. 107-114, 2006.

[26] B. Brodziak, J. Kwapuliński, and J. Rzepka, "Application of femur capitulum in estimation of the exposureto the selected heavy metals in inhabitants of industrial and recreational regions," Environmental Medicine, vol. 7, no. 2, pp. 105-111, 2004.

[27] B. Brodziak-DopieraŁa, J. Kwapuliński, J. Kowol, K. Sobczyk, and Z. Gajda, "The application of principal component analysis to interpretation of occurrence of metals in the femur head," Polish Journal of Environmental Studies, vol. 19, no. 1, pp. 49-58, 2010.

[28] B. Brodziak-Dopierała, J. Kwapuliński, D. Kusz, Z. Gajda, and K. Sobczyk, "Interactions between concentrations of chemical elements in human femoral heads," Archives of Environmental Contamination and Toxicology, vol. 57, no. 1, pp. 203-210, 2009.

[29] H.-W. Kuo, S.-M. Kuo, C.-H. Chou, and T.-C. Lee, "Determination of 14 elements in Taiwanese bones," Science of the Total Environment, vol. 255, no. 1-3, pp. 45-54, 2000.

[30] L. Patrick, "Toxic metals and antioxidants: part 2. The role of antioxidants in arsenic and cadmium toxicity," Alternative Medicine Review, vol. 8, no. 2, pp. 106-128, 2003.

[31] V. Zaichick, "INAA of $\mathrm{Ca}, \mathrm{Cl}, \mathrm{K}, \mathrm{Mg}, \mathrm{Mn}, \mathrm{Na}, \mathrm{P}$, and $\mathrm{Sr}$ contents in the human cortical and trabecular bone," Journal of Radioanalytical and Nuclear Chemistry, vol. 269, no. 3, pp. 653659, 2006.

[32] T. H. Darrah, Inorganic trace element composition of modern human bones: relation to bone pathology and geographical provenance [Ph.D. thesis], Univeristy of Rochester, New York, NY, USA, 2009.

[33] N. Lanocha, E. Kalisinska, D. I. Kosik-Bogacka, H. Budis, S. Sokolowski, and A. Bohatyrewicz, "Concentrations of trace elements in bones of the hip joint from patients after hip replacement surgery," Journal of Trace Elements in Medicine and Biology, vol. 26, no. 1, pp. 20-25, 2012.

[34] A. Jurkiewicz, D. Wiechula, R. Nowak, T. Gazdzik, and K. Loska, "Metal content in femoral head spongious bone of people living in regions of different degrees of environmental pollution in Southern and Middle Poland," Ecotoxicology and Environmental Safety, vol. 59, no. 1, pp. 95-101, 2004.

[35] S. Zaichick and V. Zaichick, "The effect of age and gender on 38 chemical element contents in human femoral neck investigated by instrumental neutron activation analysis," Biological Trace Element Research, vol. 137, no. 1, pp. 1-12, 2010.

[36] M. Vahter, M. Berglund, A. Åkesson, and C. Lidén, "Metals and women's health," Environmental Research, vol. 88, no. 3, pp. 145155, 2002.

[37] M. M. Brzóska, M. Galażyn-Sidorczuk, J. Rogalska et al., "Beneficial effect of zinc supplementation on biomechanical properties of femoral distal end and femoral diaphysis of male rats chronically exposed to cadmium," Chemico-Biological Interactions, vol. 171, no. 3, pp. 312-324, 2008.

[38] M. M. Brzóska, K. Majewska, and J. Moniuszko-Jakoniuk, "Bone mineral density, chemical composition and biomechanical properties of the tibia of female rats exposed to cadmium since weaning up to skeletal maturity," Food and Chemical Toxicology, vol. 43, no. 10, pp. 1507-1519, 2005.

[39] J. A. Jamieson, C. G. Taylor, and H. A. Weiler, "Marginal zinc deficiency exacerbates bone lead accumulation and high dietary zinc attenuates lead accumulation at the expense of bone density in growing rats," Toxicological Sciences, vol. 92, pp. 286-294, 2006.

[40] B. Brodziak-Dopierała, J. Kwapuliński, M. Bogunia, B. Ahnert, A. Paukszto, and J. Jakubowska, "Metabolism of chromium in femur head in aspect of cigarette smoking," Przegla, lekarski, vol. 63 , no. 10, pp. 1020-1022, 2006.

[41] M. Bogunia, B. Brodziak-Dopierała, J. Kwapuliński, B. Ahnert, J. Kowol, and E. Nogaj, "The occurance lead and cadmium in hip joint in aspect of exposure on tobacco smoke," Przeglad Lekarski, vol. 65, no. 10, pp. 529-532, 2008.

[42] E. Kupraszewicz and M. M. Brzóska, "Excessive ethanol consumption under exposure to lead intensifies disorders in bone metabolism: a study in a rat model," Chemico-Biological Interactions, vol. 203, no. 2, pp. 486-501, 2013.

[43] H. W. Sampson, "Alcohol, osteoporosis, and bone regulating hormones," Alcoholism: Clinical and Experimental Research, vol. 21, no. 3, pp. 400-403, 1997.

[44] V. Zaichick, S. Zaichick, V. Karandashev, and S. Nosenko, "The effect of age and gender on $\mathrm{Al}, \mathrm{B}, \mathrm{Ba}, \mathrm{Ca}, \mathrm{Cu}, \mathrm{Fe}, \mathrm{K}, \mathrm{Li}, \mathrm{Mg}, \mathrm{Mn}$, $\mathrm{Na}, \mathrm{P}, \mathrm{S}, \mathrm{Sr}, \mathrm{V}$, and $\mathrm{Zn}$ contents in rib bone of healthy humans," Biological Trace Element Research, vol. 129, no. 1-3, pp. 107-115, 2009.

[45] J. Yoshinaga, T. Suzuki, M. Morita, and M. Hayakawa, “Trace elements in ribs of elderly people and elemental variation in the presence of chronic diseases," Science of the Total Environment, vol. 162, no. 2-3, pp. 239-252, 1995. 


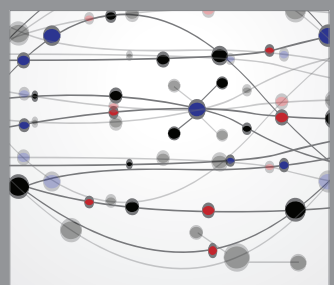

The Scientific World Journal
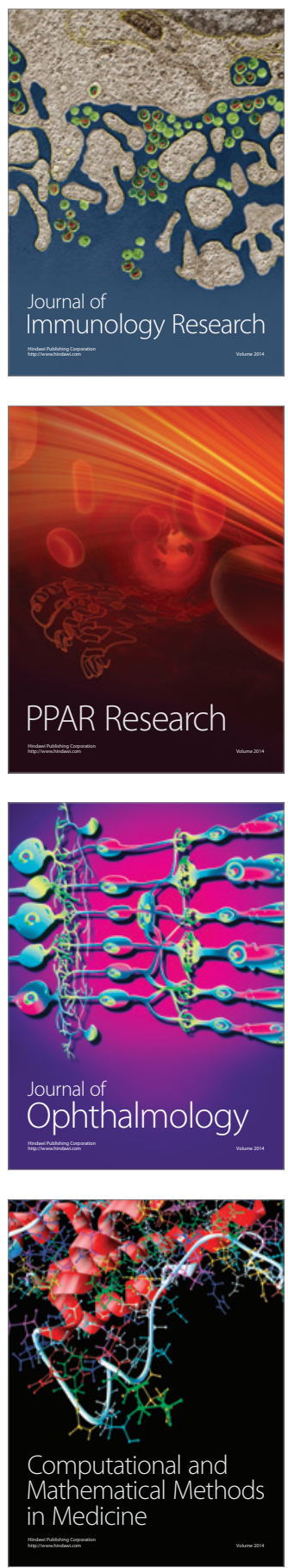

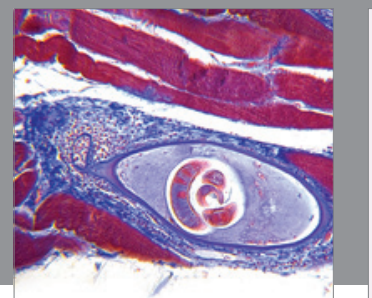

Gastroenterology

Research and Practice
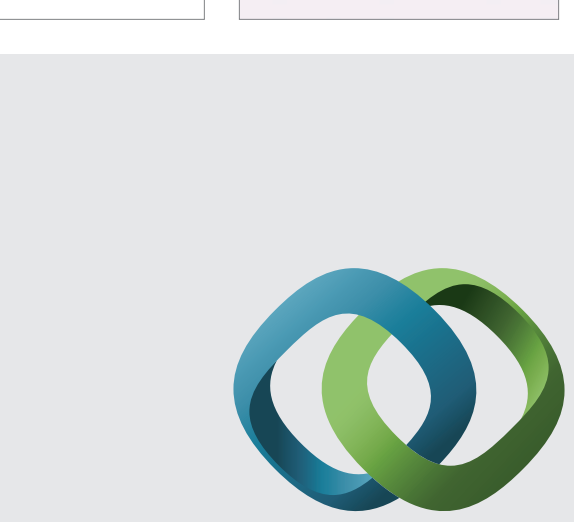

\section{Hindawi}

Submit your manuscripts at

http://www.hindawi.com
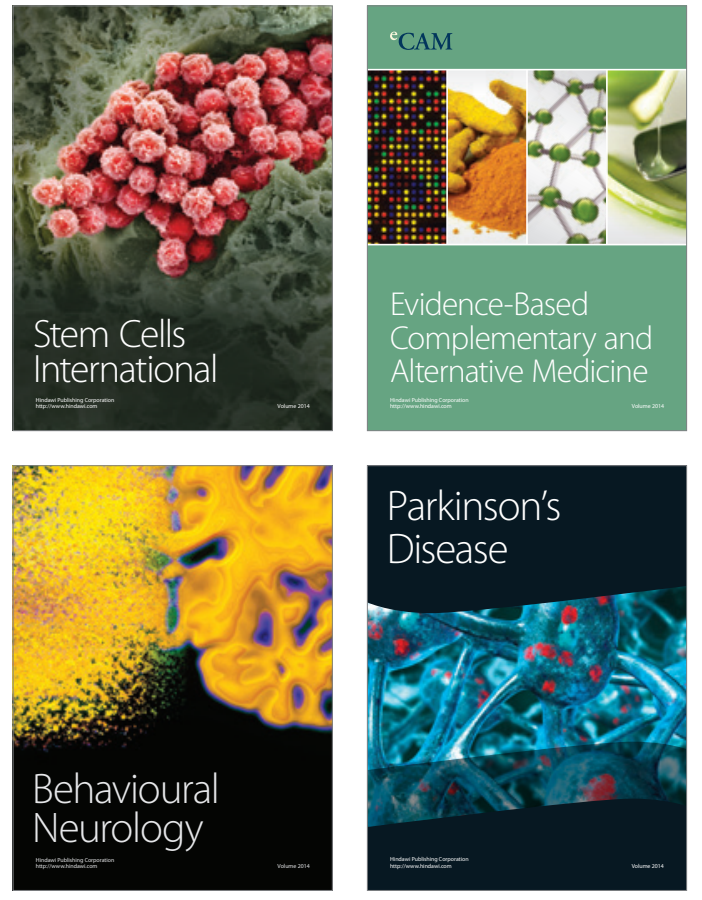
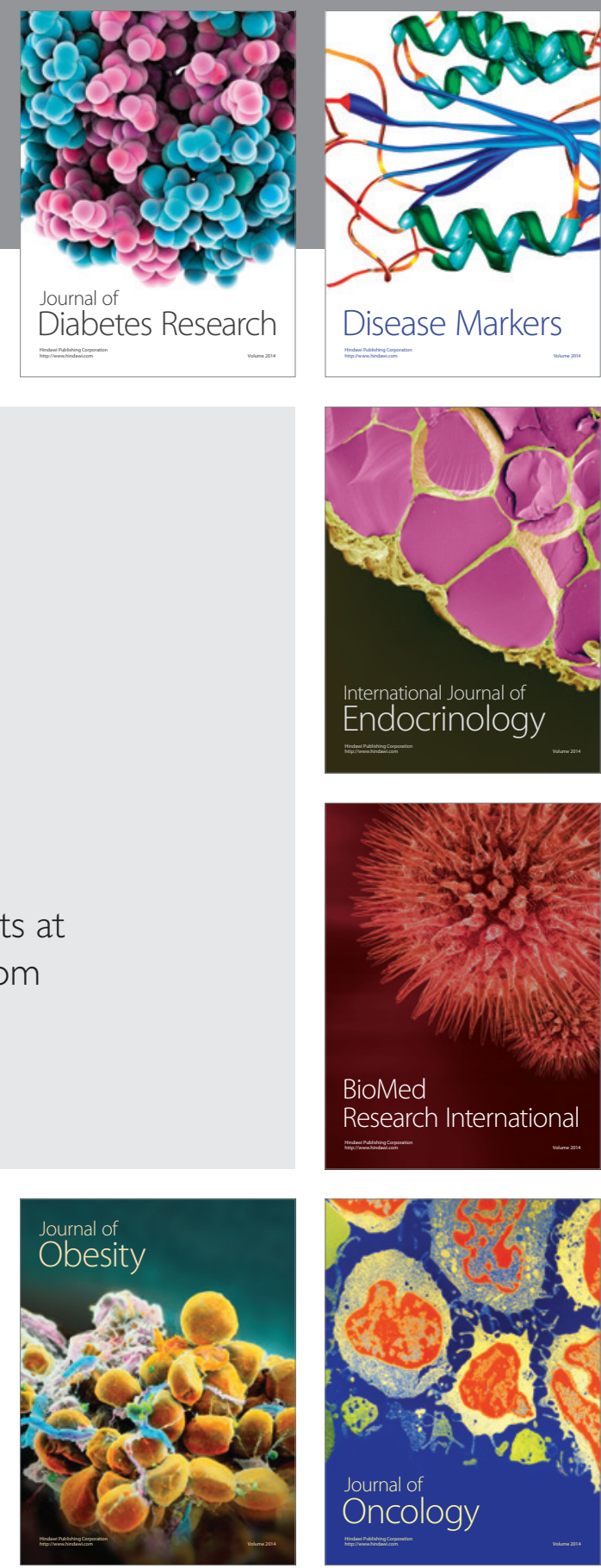

Disease Markers
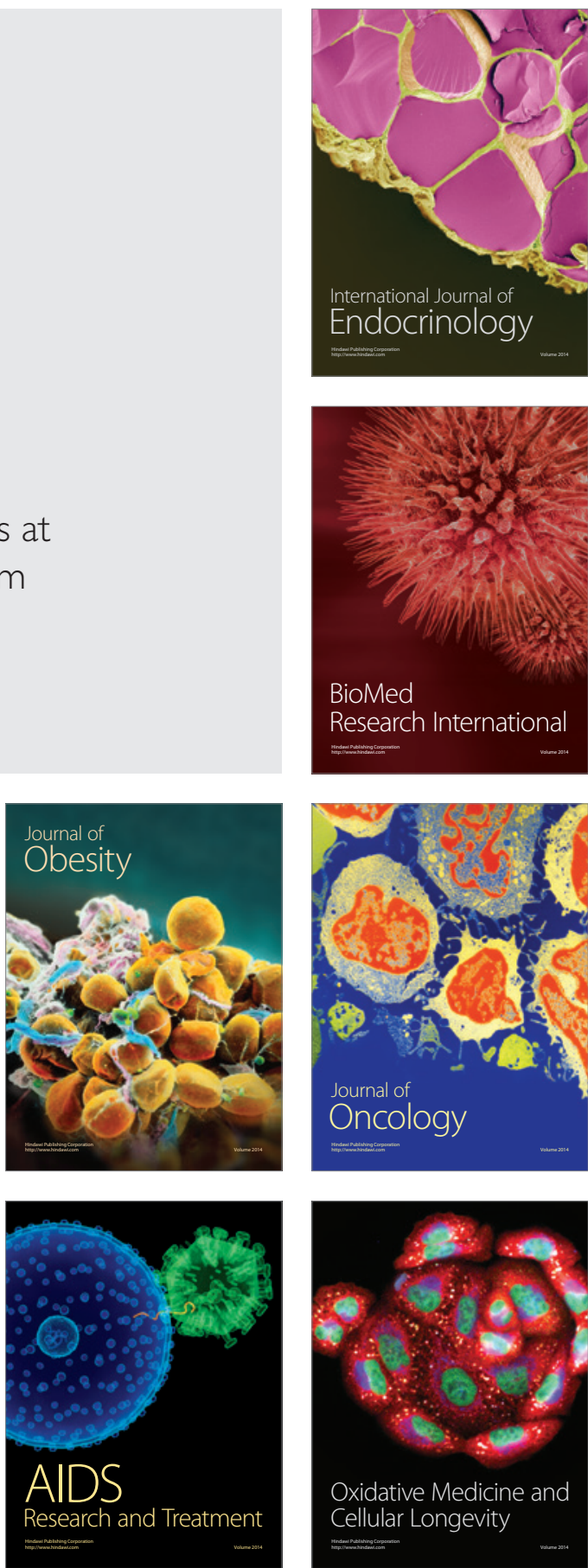